\title{
Environmental Contamination and Human Exposure to Select Endocrine-Disrupting Chemicals: A Review
}

\author{
Seethappan Sangeetha ${ }^{1}$, Krishnamoorthi Vimalkumar ${ }^{1,2}$ and Bommanna G. Loganathan ${ }^{3, *(D)}$ \\ 1 Department of Environmental Biotechnology, Bharathidasan University, \\ Tiruchirappalli 620 024, Tamil Nadu, India; sangeethaseeth@gmail.com (S.S.); \\ vimalecodynamics@gmail.com (K.V.) \\ 2 New York University School of Medicine, NYU Langone Health, New York, NY 10016, USA \\ 3 Department of Chemistry and Watershed Studies Institute, Murray State University, Murray, KY 42071, USA \\ * Correspondence: bloganathan@murraystate.edu
}

Citation: Sangeetha, S.; Vimalkumar, K.; Loganathan, B.G. Environmental Contamination and Human Exposure to Select Endocrine-Disrupting Chemicals: A Review. Sustain. Chem. 2021, 2, 343-380. https://doi.org/ 10.3390 /suschem 2020020

Academic Editor:

Ioannis Katsoyiannis

Received: 22 December 2020

Accepted: 14 May 2021

Published: 31 May 2021

Publisher's Note: MDPI stays neutral with regard to jurisdictional claims in published maps and institutional affiliations.

Copyright: (c) 2021 by the authors. Licensee MDPI, Basel, Switzerland. This article is an open access article distributed under the terms and conditions of the Creative Commons Attribution (CC BY) license (https:// creativecommons.org/licenses/by/ $4.0 /)$.

\begin{abstract}
Endocrine-disrupting compounds (EDCs) are exogenous compounds that interfere with the normal hormone functions and ultimately lead to health disorders. Parabens, phenols, and phthalates are well-known EDCs, produced globally in large quantities and widely used in a variety of applications. Several studies have monitored these compounds in a variety of environmental matrices, including air, water, sediment, fish, human tissues, soil, indoor dust, and biosolids, etc. In recent years, environmental contamination and human exposure to these chemicals have become a great concern, due to their residue levels exceeding the permissible/acceptable limits. In this review, we focus on the origin of these EDCs, aquatic contamination pathways, distribution, human exposure, health implications, and healthcare costs. Further, this review identifies critical challenges and future research needs in removing or minimizing environmental contamination and exposure to these chemicals to protect living resources.
\end{abstract}

Keywords: endocrine-disrupting compounds; wastewater treatment plant; human exposure; foodpacking materials

\section{Introduction}

Endocrine-disrupting compounds (EDCs) were defined by the WHO in 2002 as chemicals that interfere with the function of natural hormones in the biota. EDCs are exogenous compounds that interfere with the synthesis, secretion, transport, binding, and action/elimination of natural hormones, which maintain the growth, reproduction, development, and/or behavior of the organism [1,2]. Accumulation of EDCs results in sterility, sexual underdevelopment, unbalanced sexual behavior, disruption in thyroid or adrenal cortical function, raised risk for certain cancers, birth defects, immunosuppression, enhanced immune stimulation, and autoimmunity [3,4]. In this review, we focus on parabens, phenols, and phthalates and their derivatives, which are potent EDCs and cause environmental and health problems on a global scale.

Parabens are alkyl esters of $p$-hydroxybenzoic acid and are used as ingredients in certain cosmetics, pharmaceuticals, and foodstuffs due to their broad-spectrum antimicrobial properties. Synthetic phenols (phenolic antioxidants) are widely used in foods, pharmaceuticals, cosmetics, plastics, and rubber products to prevent oxidative degradation of these materials. Phthalates are used as plasticizers in numerous consumer products and building materials. Phthalates are large-volume production chemicals. Several million tons of phthalates and their derivatives are produced worldwide every year for the production of soft polyvinyl chloride (PVC) and other plastics. Due to extensive use of these compounds, global environmental contamination and harmful effects (particularly as an endocrine disruptor) on wildlife and humans are eminent. This review deals with: (i) the mechanism of action of EDCs; (ii) parabens, phenols, and phthalates in environmental matrices (water, 
soil/sediment) and biota (fish); (iii) human exposure; and (iv) health implications and healthcare costs.

\section{Mechanism of Action of EDCs}

EDCs may alter the endocrine system via a direct or indirect mechanism. Directly, EDCs act as an antagonist on nuclear hormone receptors, including estrogen receptors (ERs), androgen receptors (ARs), progesterone receptors, thyroid receptors (TRs), insulin receptors (IR) and retinoid receptors, to imbalance the homeostasis of hormones [5]. Binding of EDCs on hormonal receptors had results of either stimulation or inhibition of the downstream cellular pathway in target cells [6] (Figure 1). EDCs can elicit an adverse effect on endogenous hormone regulation by binding or stimulating hormone receptors or altering hormone concentrations, or by modifying the hormone binding receptor turnover $[4,7]$. EDCs can affect the endocrine system through nine modes of action (Figure 2).

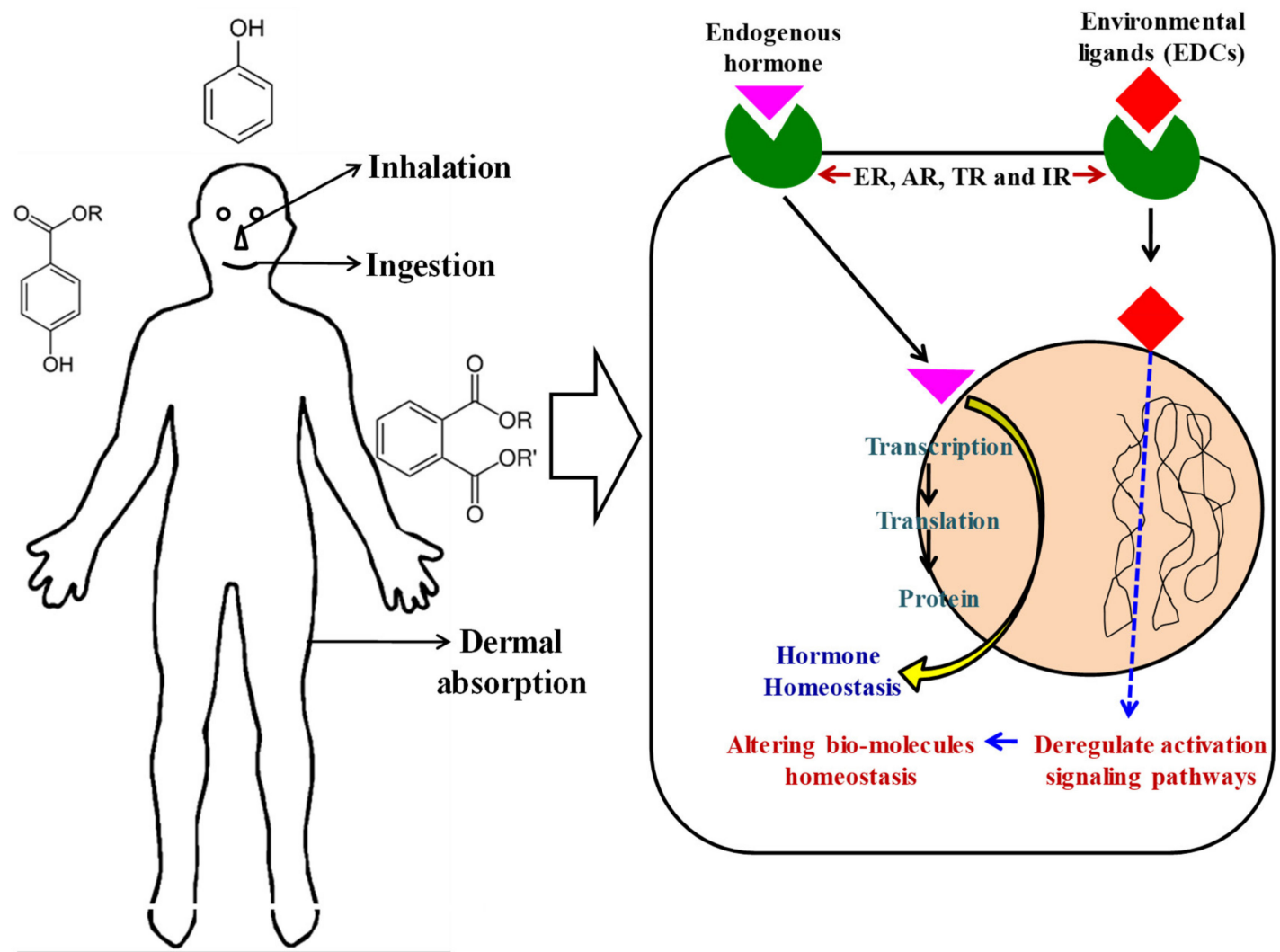

Figure 1. Human exposure to EDCs and their effects at the molecular level.

Inappropriate activation/binding of hormone receptors by EDCs could lead to negative effects on human health [8]. Some of the above-mentioned EDCs inappropriately activate the estrogen receptor during the developmental stage, which results in infertility in both the sexes. For example, dichloro-diphenyl-tricloroethane (DDT) binds to the estrogen receptor $\alpha(E R \alpha)$ and estrogen receptor $\beta(E R \beta)$, influencing the stimulation of ER-dependent transcriptional activation and proliferation. Further, DDT also binds to the follicle-stimulating hormone receptor and G protein coupled receptors (GPCR), enhancing cAMP production [9-11]. EDCs act as receptor antagonists, and inhibit or block the endogenous hormone [12]. DDT also inhibits the binding of androgen to the androgen receptor (AR), further preventing the androgen-dependent transactivation of AR in humans [13]. Concentrations of hormones were determined by the abundance of receptors, as well as the reaction of hormones in certain situations. Expression, internalization, and degradation of hormone receptors were modulated by EDCs. Aldosteron receptor expression was 
decreased by di(2-ethylhexyl) phthalate. On the other hand the aldosteron receptor acted as a positive modulator of testosterone biosynthesis.

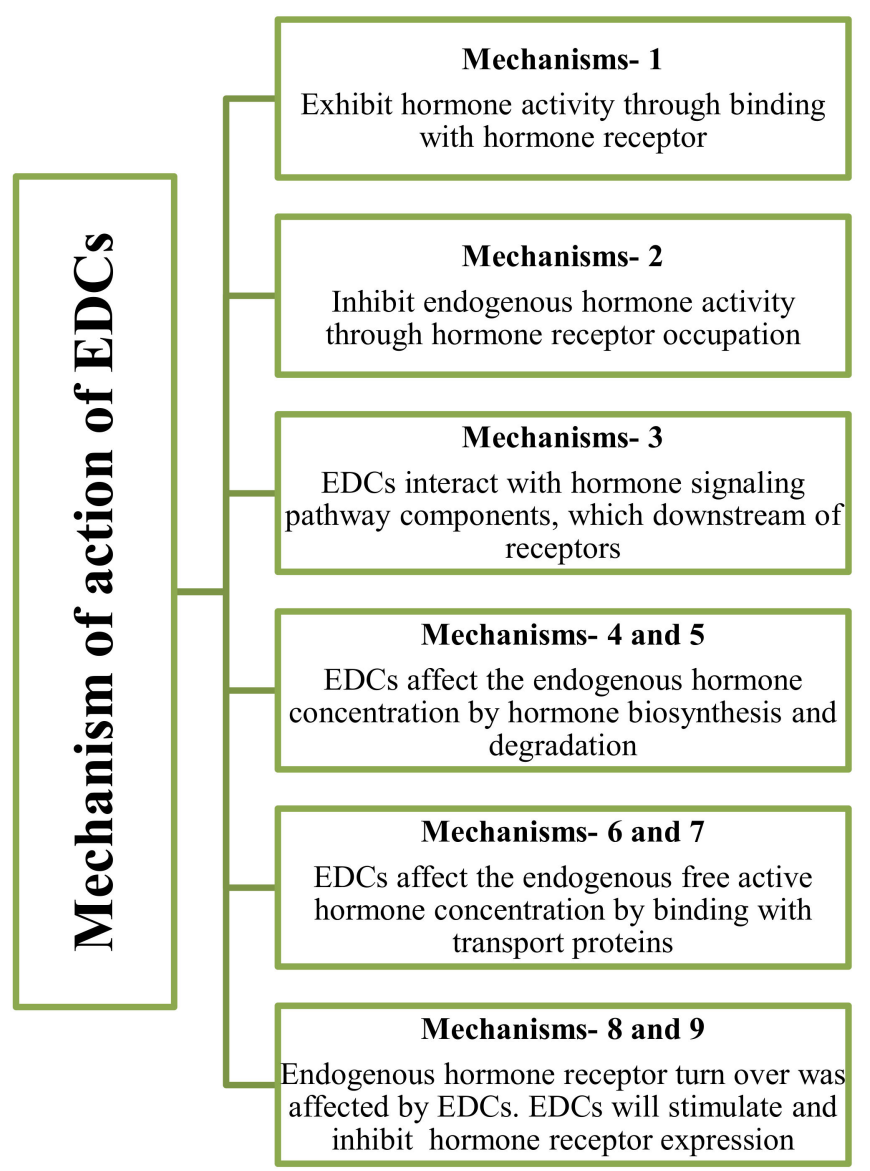

Figure 2. Mechanism of action of EDCs.

Intracellular response was triggered by the binding of hormones to a receptor and tissue-specific properties of the target cell. EDCs could alter the signal transduction through membrane and intracellular hormone receptors. These two classes of receptors are: cell surface membrane receptors and nuclear steroid hormone receptors. Hormones are involved in development and differentiation by modifying the epigenetic process. These cascade actions were perturbed by EDCs. Important key enzyme expressions were also increased by pesticides such as methoxychlor [14-16].

Hormones (steroid hormones-estrogen, androgen, progestogen, and adrenal steroids) are liphophilic in nature, and passively move through membranes. The transport of these hormones was disturbed by EDCs. A low dose of BPA reduced calcium entry into pancreatic $\beta$-cells. Hormones are typically transported with the transport protein (serum protein), depending on the chemistry of the hormones. They may bind with or without the conjugative protein. In such cases, EDCs displace the hormones from their transport protein, and hence the target tissue receives impaired hormones [17,18].

Further, hormones become inactive when they are broken down by proteases. This mechanism was also modulated by EDC, by affecting the degradation and/or clearance of hormones, leading to varying hormone concentrations in the bloodstream. Tissue structure was maintained by the hormones via cellular proliferation and differentiation. Endocrine organs having a stable number of cells were altered by the EDCs by disrupting or promoting cell numbers. Polychlorinated biphenyls (PCBs), a well-known EDC, could interfere with thyroid hormone signaling and cause abnormal morphology of the endocrine organ $[19,20]$. 


\section{Applications/Use of Compounds That Elicit Endocrine-Disrupting Properties}

EDCs are substances used in industries as well as in consumer products for various uses (flame retardants, cosmetics and personal care products, etc.) [21]. Some of the major EDCs are polychlorinated biphenyls (PCBs), dioxins, alkylphenols (APs), polybrominated biphenyls (PBBs), plastics (bisphenol A (BPA)), plasticizers (phthalates), pesticides, fungicides, steroids, and pharmaceutical agents. Various sources of EDCs are shown in Figure 3. Approximately 38,000 chemicals have been suspected as endocrine disruptors [2]. These compounds enter into the environment by various sources, such as effluents from wastewater treatment plants (WWTPs), seepage from septic tanks and landfill sites, surface water run-off, etc. Industrialized areas were contaminated with a wide range of these chemicals as they percolated into the soil and groundwater and ultimately bioaccumulated in fish and other aquatic animals. Recent studies reported that the above-mentioned EDCs have thyroid-disrupting characteristics [22,23]. In this review, we focus on parabens, phenols, and phthalates due to their large-scale production, widespread use, and frequently detected compounds in almost all the environmental matrices.

\section{Sources of Endocrine Disrupting Chemicals (EDCs)}

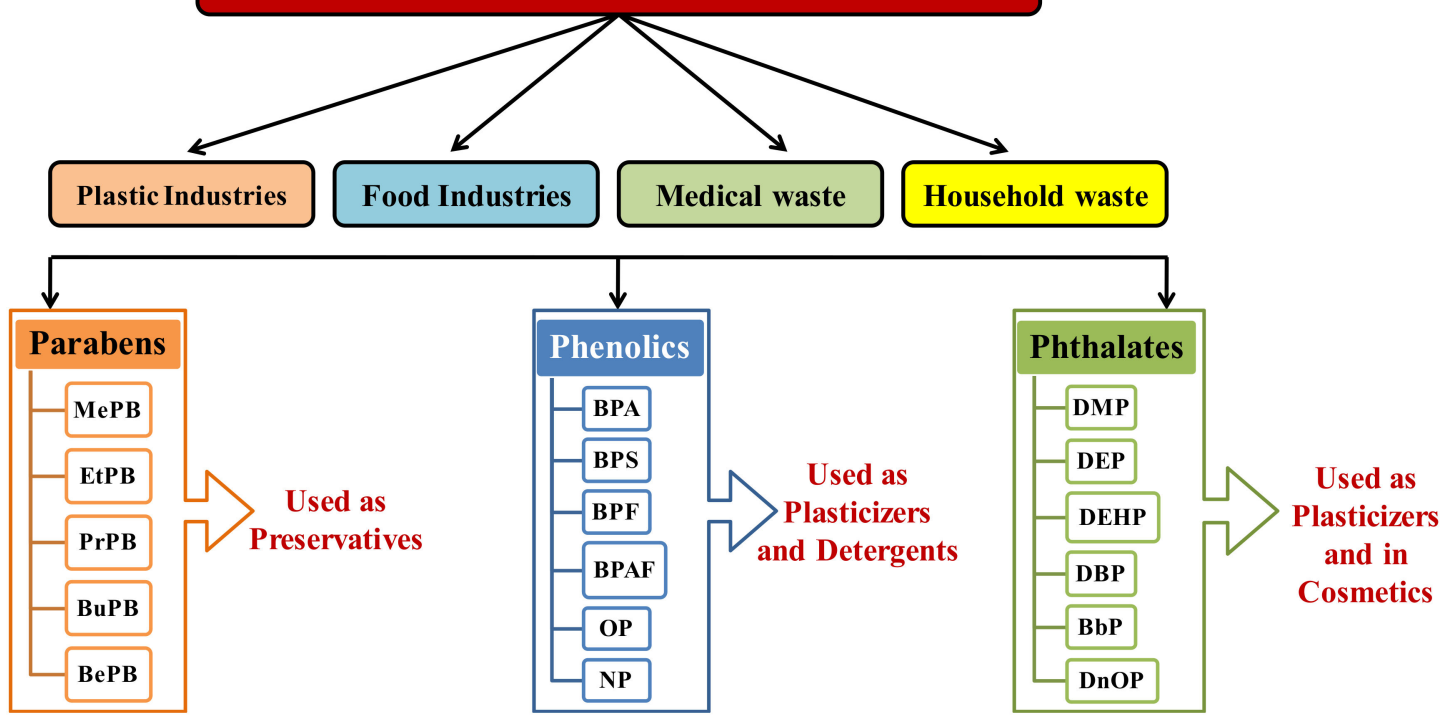

Figure 3. Types and sources of EDCs.

Parabens (PBs) are $p$-hydroxybenzoic acid (pHBA) esters [24], applied as antimicrobial preservatives in consumer and personal care products (cosmetics, toiletries, pharmaceuticals, food, animal feed, and healthcare products) and industrial products (cigarettes, varnishes, and glue), and their residues were found in currency bills and paper products, including sanitary wipes [25] (Figure 3). PBs are classified into two types based on the length of alkyl chains:

- $\quad$ Short-chain parabens: methyl paraben (MePB) and ethyl paraben (EtPB);

- Long-chain parabens: propyl paraben (PrPB), isopropyl paraben (iPrPB), butyl paraben (BuPB), isobutyl paraben (iBuPB), and benzyl paraben (BePB) [26].

$\mathrm{MePB}$ was used as a plasticizer in pharmaceuticals and medicine production [27]. Methyl and propyl parabens were predominantly used, among others, to increase preservative effects [28]. Antimicrobial properties are directly related to the chain length of the ester groups in PBs [29]. Due to their recalcitrant properties, PBs were found in almost all environmental matrices, including surface water (rivers, lakes and coasts), drinking water, sediments, soils, indoor dust, sludge, marine mammals, and human tissues [30-38].

Byproducts of parabens were more toxic to aquatic organisms than parent compounds. Chlorinated byproducts can be formed due to the reaction between parabens in cosmetics 
and chlorinated tap waters [39]. Chlorinated paraben residues were reported in wastewater and sludge [40], which is of great concern due to the lack of information regarding their occurrence in environmental matrices, and the effects of these compounds in aquatic organisms. [41]. Occurrence of PBs and their byproducts in environmental samples and harmful effects on aquatic organisms prompted Denmark to ban the usage of parabens in personal care products, including PrPB and BuPB in children's cosmetic products [42]. Metabolites of parabens such as 4-hydroxybenzoic acid (4-HB), 3,4-dihydroxybenzoic acid (3,4-DHB), benzoic acid (BA), methyl protocatechuate (OH-MePB), and ethyl protocatechuate (OH-EtPB) were also considered as EDCs [43]. Paraben metabolites including 4-HB and 3,4-DHB elicit estrogenic activity and contribute to obesity, respectively [44].

Bisphenols are plastic monomers and plasticizers. Bisphenol A (BPA) has been used in the production of polycarbonates and epoxy resin flame retardants as an intermediate (Figure 3). Due to the endocrine-disrupting effects of BPA, replacements such as bisphenol $\mathrm{S}$ (BPS) and bisphenol F (BPF) were produced and used. A recent study has shown that these replacement chemicals also interfere with hormone signaling pathways [45]. Bisphenol $\mathrm{S}$, bisphenol $\mathrm{F}$ and bisphenol AF are widely used in the production of plastics, thermal paper receipts, and food packaging materials [46]. Exposure to bisphenol via food and food packaging are probable sources of endocrine hormone system interference [47]. BPA can interfere with different hormonal systems, through interaction with hormonal receptors (androgen, estrogen, glucocorticoid, or thyroid receptors) [48]. To prevent the endocrinedisrupting effect of BPA in babies, the European Union banned the usage of BPA-containing polycarbonates in baby bottles [49]. Several studies have reported bisphenols in various environmental matrices, such as surface water, wastewater, tap water, sediment, indoor dust, and human urine and plasma [50-57].

Nonylphenolethoxylates (NPEOs) and alkyl ethoxylates (AEOs) are nonionic surfactants used as detergents, emulsifiers, humidifiers, stabilizers, skimmers, and intermediates in the synthesis of various products in industries [58]. Degradation of alkylphenolpolyethoxylates (APEOs) and AEOs results in the formation of alkylphenols, alkylphenolmonoethoxylates, and alkylphenoldiethoxylates, which are considered as EDCs [59]. APEOs are broken down into nonylphenols (NPs) or octylphenols (OPs); metabolites from NPEOs are found in sediments [60]. These two compounds are persistent in the environment. Due to the widespread use of NPEOs and APEOs, their degradation products (NPs and OPs) were detected in rivers, lakes, sediments, and reservoirs. Reports suggest that aquatic organisms were highly affected by the contamination with these persistent organic chemicals [61,62].

Phthalates are common plasticizers in rigid and malleable plastics [63] and are used in various industries including food packaging industries. Phthalate esters (PAEs) easily migrate from plastic products into food materials, as they are not chemically bound with the products [64]. Phthalates are categorized into two groups:

- Short-chain phthalates: dimethyl phthalate (DMP) and dibutyl phthalate (DBP);

- Long-chain phthalates: butyl-benzyl phthalate (BBP), di-n-hexyl phthalate (DNHP), di-2-ethylhexyl phthalate (DEHP), di-n-octyl phthalate (DNOP), di-iso-nonyl phthalate (DINP), and di-iso-decyl phthalate (DIDP).

Production and usage of phthalates (PAEs) varies with their chain length. Short-chain phthalates are used in personal care products, while long-chain phthalates are used in furniture manufacturing industries, clothing, building materials, and the production of polyvinyl chloride (PVC) plastics (Figure 3) $[65,66]$. Human exposure to phthalates occurs through ingestion, inhalation, and dermal adsorption from air, food, water, dust and soil, etc. [67]. Exposure to PAEs in humans results in the occurrence of phthalate metabolites in human urine and blood [68]. Phthalate exposure contributes to intellectual disability, immunological deficiency, and suspected to cause cancer [69]. Phthalates are structurally similar to fats and have a high binding affinity toward them; hence fatty foods wrapped up in these plastics are most vulnerable to contamination by phthalates. An study conducted by Schecter et al. showed percentage detection of phthalates in food purchased in New 
York: DMP (37\%), DBP (31\%), DIBP (55\%), BBP (54\%), DNHP (15\%), DEHP (74\%), and DNOP (12\%) [70]. The report revealed widespread contamination of PAEs in food [71]. Experimental studies provided evidence that the development and reproduction of males and females have been affected by phthalates. A recent study by Benjamin et al. reported the effects of phthalates on the endocrine system in men and women [72].

The fate and adverse effects of EDCs on the environment and human health attracted researchers to monitor these compounds; however, it was challenging to determine various analytes in different matrices due to different physico-chemical properties [40]. EDCs had been detected in various environmental matrices and biota at part per billion (ppb) and part per trillion (ppt) levels [73]. Long-term, low-level exposure to EDCs costs the United States USD 340 billion in annual healthcare spending and lost wages. The cost of natural resources lost due to chemical pollution has yet to be determined. This review focuses on contamination of EDCs in different environmental matrices (water, sediment, soil, and fish), human exposure, and possible implications.

\section{Endocrine-Disrupting Compounds in Environmental Matrices \\ 4.1. Parabens in Water}

The distribution of parabens in water from different locations is given in Table 1. MePB and PrPB are commonly used in cosmetics, which influences the abundance of these two compounds in water samples [74]. The concentrations of MePB and PrPB in water samples from Chinese rivers (Pearl River Delta) were 1062 ng/L and 3142 ng/L, respectively [75]. Relatively lower concentrations of MePB and PrPB (400 ng/L and $69 \mathrm{ng} / \mathrm{L}$, respectively) were reported in European rivers [76]. Ramaswamy et al. [77] reported lower levels of EtPB (147 ng/L) and BuPB (163 ng/L) in water samples from Indian rivers; these were less frequently detected than MePB and PrPB. Higher production and use of these two parabens resulted in frequent detection in water samples from Japanese rivers [78]. Very few studies reported the presence of BePB in river waters. The Glatt River contained a very low concentration $(4.4 \mathrm{ng} / \mathrm{L})$ of BePB in its surface waters [79]. Distribution and concentration of contaminants depended on the seasonal variation and dilution factor. For example, low flow conditions resulted in higher PB concentrations because of pollutants dissolved in smaller volumes of water [75]. However, higher concentrations of PBs were recorded during high water flow conditions due to direct discharge of wastewater into the river. Seasonal variations of PBs should be taken in account while monitoring PBs contamination in aquatic systems.

Relatively higher levels of contamination of parabens were found in coastal zones or in rivers close to point-source areas such as factories manufacturing paraben-containing products and wastewater discharges from WWTPs (Table 1). Based on the half-life of parabens in water, these compounds may have very low persistence in aquatic environments [80]. Insufficient removal of parabens in conventional WWTPs, random discharges, or leakage of municipal wastewater into water streams results in frequent detection at low concentrations (range: $\mu \mathrm{g} / \mathrm{L}-\mathrm{ng} / \mathrm{L}$ ) of PBs in river water samples. Municipal landfill leachates also resulted in paraben contamination in water systems, and two untreated leachates were found with three paraben (MePB, PrPB, and BuPB) concentrations of 3480-7930, 900-1820, and 420-470 ng/L respectively, while EtPB was not detected [81].

Paraben concentrations in WWTP effluents were relatively high when compared to the river waters, that received the wastewater discharge, due to higher dilution in the water, biodegradation, and adsorption of parabens in sediments. Jonkers et al. [24] reported MePB (range: $2.1-51 \mathrm{ng} / \mathrm{L}$ ) in a shallow estuarine system in northwestern Portugal, and concentrations of EtPB (6.7 ng/L), PrPB (7.9 ng/L), and BuPB (7.1 ng/L) were comparatively lower than MePB. The maximum concentration of $\mathrm{BzPB}$ was $0.3 \mathrm{ng} / \mathrm{L}$, and the major source of paraben contamination in the water was rivers discharging into the lagoon. MePB and PrPB were reported in seawater samples from China (104 ng/L and $69.9 \mathrm{ng} / \mathrm{L})[82,83]$, Portugal (up to $21 \mathrm{ng} / \mathrm{L}$ and $1.6 \mathrm{ng} / \mathrm{L}$ ) [24], and Antarctica (up to $33.3 \mathrm{ng} / \mathrm{L}$ and $3 \mathrm{ng} / \mathrm{L}$ ) [84]. MePB (median: $2.21 \mathrm{ng} / \mathrm{L}$ ) was the abundant compound in the Pearl River estuary, fol- 
lowed by PrPB (1.12 ng/L) and EtPB (0.94 ng/L). Similarly, Sun et al. [82] reported MePB (2.65-29.1 ng/L) and PrPB (1.11-5.22 ng/L) in aqueous samples from the Jiulong River estuary in China. Florida coastal waters (USA) were contaminated with parent parabens, including MePB (3.02-31.7 ng/L), EtPB (6.12-7.09 ng/L), and PrPB (<0.5-9.04 ng/L) [85]. Foods, personal care products, and pharmaceuticals containing $\mathrm{MePB}, \mathrm{PrPb}$, and EtPB contribute significant amounts of these compounds to the environmental contamination (Table 1) [31,86].

\subsection{Parabens in Soil and Sediment}

Sediments are the ultimate repository of organic contaminants, including parabens [28]. Sediment samples from different countries were found with significant concentrations of parabens (Table 1). Sediment samples from Spain (Canary Islands, Tenerife) contained $377 \mathrm{ng} / \mathrm{g} \mathrm{dw}$ BuPB [87]. Viglino et al. [88] reported relatively low level of parabens (MePB: up to $127 \mathrm{ng} / \mathrm{g} \mathrm{dw}$; EtPB, PrPB, and BuPB: up to $15-23 \mathrm{ng} / \mathrm{g} \mathrm{dw}$ ) in sediments and soils from Canada. Sediment samples that were collected far from anthropogenic activities were not contaminated with parabens [88]. Carmona et al. analyzed Turia River (east of Spain) sediments and reported $476 \mathrm{ng} / \mathrm{g}$ MePB, followed by EtPB (60 ng/g), PrPB (64.5 ng/g), and $\mathrm{BuPB}(34 \mathrm{ng} / \mathrm{g}$ ) [36]. However, sediment samples from Asan Lake in Korea revealed a different profile of contamination. Total concentrations of parabens and their metabolites ranged from 0.19 to $11.2 \mathrm{ng} / \mathrm{g} \mathrm{dw}$ and 9.65 to $480 \mathrm{ng} / \mathrm{g} \mathrm{dw}$, respectively. Concentrations of $4-\mathrm{HB}$ and MePB in sediments ranged from 9.65 to $446 \mathrm{ng} / \mathrm{g} \mathrm{dw}$ and 0.13 to $11.2 \mathrm{ng} / \mathrm{g}$ $\mathrm{dw}$, respectively, and 4-HB was the predominant compound among other parabens [89]. The residues of 4-HB were found in environmental (sediment) as well as in biological tissues (bivalves and marine mammals) [32,90]. A few studies have reported contamination of MePB in sediments from the Florida coast (USA) (3.03 ng/g dw), Tokyo Bay (Japan) (5.04 ng/g dw), and the Pearl River (2.95 ng/g dw) and Yangtze River (4.95 ng/g dw) in China [91,92]. Relatively elevated concentrations of MePB were found in sediments from Spain and China $[92,93]$. Low WWTP operational rates in the eastern part of the Korean coastline (Gangwon Province) and comparatively higher WWTP operational rates in the western part of Korea (Gyeonggi Province and Seoul) might have contributed to the variations in concentrations of parabens reported [94]. The areas of the Yeongil and Masan Bays are highly industrialized with slow tidal currents, which might have contributed to a comparatively greater concentration of parabens and their metabolites in sediments than other regions in Korea $[95,96]$.

Parabens and their metabolites were reported in soil samples from agricultural and forestry areas, as well as in sediments from different regions of Spain. The detected concentrations of $\mathrm{MePb}, \mathrm{EtPB}, \mathrm{iPrPB}, \mathrm{PrPB}, \mathrm{BePB}$, and $\mathrm{BuPB}$ were 6.35, 5.10, 0.29, 4.03, 0.45, and $0.71 \mathrm{ng} / \mathrm{g}$ dry weight $(\mathrm{dw})$, respectively [28]. Several PBs that were detected in agricultural soils were attributed to amendments of sewage sludge and industrial soils. These activities caused the prevalence of PBs in these samples. The $\mathrm{PB}$ concentrations reported were: $\mathrm{MePB}$ (up to $8.04 \mathrm{ng} / \mathrm{g} \mathrm{dw}$ ) $>$ EtPB (up to $1.23 \mathrm{ng} / \mathrm{g} \mathrm{dw}$ ) $>$ BuPB $(1 \mathrm{ng} / \mathrm{g} \mathrm{dw}$ ) [97]. Garden soil was found containing PrPB at $1.5 \mathrm{ng} / \mathrm{g} \mathrm{dw}$ [98]. The occurrence of PBs in sediment will eventually influence the bioaccumulation in fish.

\subsection{Parabens in Biota/Fish}

Parabens are known to bioaccumulate in fish and other organisms in the aquatic environment. Jakimska et al. [33] reported relatively low concentrations of MePB $(84.69 \pm 6.58 \mathrm{ng} / \mathrm{g})$ and $\operatorname{PrPB}(0.19 \pm 0.04 \mathrm{ng} / \mathrm{g})$ in fish tissues. However, parabens were not detectable in fish brain tissues [38]. Slightly elevated levels $(7 \mathrm{ng} / \mathrm{g} \mathrm{dw})$ of MePB were reported from the northern coast of Spain, and n-propylparaben ( $n$-PrPB) was barely detectable $(0.56 \mathrm{ng} / \mathrm{g} \mathrm{dw})$ and reported only in one mussel sample from this region [99]. Similarly, a very low concentration $(0.37 \mathrm{ng} / \mathrm{g} \mathrm{dw})$ of EtPB was found in mussel and cockle samples. The detected paraben concentrations in fish samples were at the same order of magnitude in relation to the ambient water and treated wastewater. [99]. 
Kim et al. [34] reported four parabens in three fish species from the marine waters of Manila Bay, the Philippines. The order of reported concentrations were: MePB (505-3450 ng/g lipid weight (lw)) > PrPB (46-1140 ng/g lw) > EtPB (46.6-195 ng/g lw) > $\mathrm{BuPB}(6.61-37.3 \mathrm{ng} / \mathrm{g} \mathrm{lw})$ in muscle tissues of all species. Large production and usage of PBs and direct release of untreated wastewater into Manila Bay led to higher concentrations of MePB and PrBP in different fish species. Another study from the same area (using fish muscle tissue purchased from local markets in Manila Bay) showed a similar range of concentration of PBs. The reported levels were: MePB $(<0.05-3600 \mathrm{ng} / \mathrm{g} l \mathrm{lw})$, followed by EtPB $(<0.011-840 \mathrm{ng} / \mathrm{g}$ lw), PrPB $(<0.024-1100 \mathrm{ng} / \mathrm{glw})$, and BuPB $(<0.003-70 \mathrm{ng} / \mathrm{g} \mathrm{lw})$ [35]. The detected paraben values were two orders of magnitude higher in adult fish (coral grouper) $(4700 \mathrm{ng} / \mathrm{g}$ ) than in juveniles $(220 \mathrm{ng} / \mathrm{g}$ ), which indicated age-related accumulation of parabens [35]. The above-mentioned reports provide evidence that parabens are ubiquitous contaminants in the coastal waters of the Philippines, and that these compounds bioaccumulate in fish. Jakimska et al. [33] found parabens in 12 different species collected from four Mediterranean rivers. They found PrPB in fish homogenates at $0.19 \pm 0.04 \mathrm{ng} / \mathrm{g} \mathrm{dw}$, and MePB at $84.69 \pm 6.58 \mathrm{ng} / \mathrm{g} \mathrm{dw}$. The Salmo trutta species was found with higher concentrations of MePB and $\mathrm{PrPB}$, and the sample collection site was contaminated by effluent from a wastewater treatment plant. Renz et al. [38] analyzed parabens (MePB, EtPB, PrPB, and $\mathrm{BuPB}$ ) in 58 fish (brain tissue) collected from Pennsylvania rivers in Pittsburgh (USA). PBs were not detectable in any of the samples analyzed.

According to $\mathrm{Lu}$ et al. MePB concentration in shellfish ranged from $1.29 \times 10^{2}$ to $2.48 \times 10^{4} \mathrm{pg} / \mathrm{g}$, which was similar to the concentration of this compound in clam tissues (from the Antarctic coastal environment) and bivalve mollusks (from Florida) $\left(0.4 \times 10^{3}-1.0 \times 10^{3}\right)[85,100]$. PrPB concentration in shellfish $(<\mathrm{LOQ}-406 \mathrm{pg} / \mathrm{g})$ was lower than in fish samples from Antarctic coastal waters $\left(0.4 \times 10^{3}-1.9 \times 10^{3} \mathrm{pg} / \mathrm{g}\right)$, as well as from the Florida coast $\left(<2.01 \times 10^{3} \mathrm{pg} / \mathrm{g}\right)$. Median concentrations of MePB $(905 \mathrm{pg} / \mathrm{g})$, EtPB (40.9 pg/g), PrPB (20.6 pg/g), BuPB (<LOD pg/g), and BePB $(<\mathrm{LOD} \mathrm{pg/g})$ in shellfish from Shenzhen (China) were in a similar range with MePB (336 pg/g), EtPB $(9 \mathrm{pg} / \mathrm{g}), \operatorname{PrPB}(42 \mathrm{pg} / \mathrm{g})$; BuPB and BePB were barely detected (5 pg/g each analyte) in fish and shellfish from the USA [101]. MePB, EtPB, and PrPB concentrations in shellfish from different countries were reported, such as Portugal (MePB: $4.5 \times 10^{3} \mathrm{pg} / \mathrm{g}$; EtPB: $0.3 \times 10^{3} \mathrm{pg} / \mathrm{g}$; PrPB: $0.9 \times 10^{3} \mathrm{pg} / \mathrm{g}$ ), Italy (MePB: $11.3 \times 10^{3} \mathrm{pg} / \mathrm{g}$; EtPB: $0.3 \times 10^{3} \mathrm{pg} / \mathrm{g}$; PrPB: $2.8 \times 10^{3} \mathrm{pg} / \mathrm{g}$ ), and the northern coast of Spain (MePB: $<\mathrm{LOQ}-7.0 \times 10^{3} \mathrm{pg} / \mathrm{g}$; EtPB: $<$ LOQ-3.7 × 10 2 pg/g; PrPB: <LOQ-5.6 × $10^{2} \mathrm{pg} / \mathrm{g}$ ) [99,102]. MePB has a high water solubility and is more available in ambient water than other parabens, which accounts for the higher concentration of MePB in fish. Based on the above studies, it can be surmised that MePB was the predominant compound among other parabens in different species and in different sampling locations.

Table 1. Concentration of parabens in water, sediment, and fish and human tissues.

\begin{tabular}{|c|c|c|c|c|c|c|c|c|}
\hline Sampling Area & МePB & EtPB & PrPB & BuPB & ВePB & $n$-PrPB & Unit & Reference \\
\hline Manzanares River, Spain & & 13.5 & 32 & & & & $\mathrm{ng} / \mathrm{L}$ & \multirow{3}{*}{ [103] } \\
\hline Jarama River, Spain & & & $\begin{array}{l}4.2 \text { (Sunday) } \\
30 \text { (Thursday) }\end{array}$ & & & & $\mathrm{ng} / \mathrm{L}$ & \\
\hline $\begin{array}{l}\text { Northern Antarctic } \\
\text { Peninsula Region }\end{array}$ & 16.05 & & & & & & $\mathrm{ng} / \mathrm{L}$ & \\
\hline Rivers in the Iberian Peninsula & ND-142 & ND-49 & ND-26 & & ND-7.3 & & $\mathrm{ng} / \mathrm{L}$ & [104] \\
\hline $\begin{array}{l}\text { Ria de Aveiro (Rivers of } \\
\text { Agueda \& Vouga) }\end{array}$ & ND-45 & ND-2.2 & ND-6.2 & & & & $\mathrm{ng} / \mathrm{L}$ & [24] \\
\hline Rivers Caster \& Antua & $3.3-16$ & $<0.3-6.4$ & $<0.5-64$ & $<0.2-42$ & $<0.2-0.3$ & & $\mathrm{ng} / \mathrm{L}$ & \\
\hline Lagoon in Ria de Aveiro & $2.1-51$ & $<0.3-6.7$ & $<0.5-7.9$ & $<0.2-0.2$ & $<0.2-0.3$ & & $\mathrm{ng} / \mathrm{L}$ & \\
\hline Sea & $5.1-21$ & $<0.3-1.6$ & $<0.5-1.6$ & $<0.2-0.7$ & $<0.2$ & & $\mathrm{ng} / \mathrm{L}$ & \\
\hline Sea near outfall & $5.7-62$ & $<0.3-15$ & $<0.5-6.1$ & $<0.2-7.1$ & $<0.2$ & & $\mathrm{ng} / \mathrm{L}$ & \\
\hline
\end{tabular}


Table 1. Cont.

\begin{tabular}{|c|c|c|c|c|c|c|c|c|c|}
\hline \multicolumn{2}{|c|}{ Sampling Area } & МePB & EtPB & PrPB & BuPB & ВePB & $n$-PrPB & Unit & Reference \\
\hline \multicolumn{2}{|c|}{ Japanese rivers } & ND-525 & & & & & ND-181 & $\mathrm{ng} / \mathrm{L}$ & [78] \\
\hline \multicolumn{2}{|c|}{ Antarctic seawater } & $<0.8-37.4$ & & & & & & $\mathrm{ng} / \mathrm{L}$ & [84] \\
\hline \multicolumn{2}{|c|}{ Southern India (29 sites) } & ND-22.8 & $2.47-147$ & & & & & $\mathrm{ng} / \mathrm{L}$ & [77] \\
\hline \multicolumn{2}{|c|}{$\begin{array}{l}\text { Urban, streams in Tokushima } \\
\text { and Osaka, Japan (12 sites) }\end{array}$} & $25-676$ & $<1.3-64$ & $<0.8-207$ & $<0.6-163$ & $<0.2-2.3$ & & $\mathrm{ng} / \mathrm{L}$ & [105] \\
\hline \multicolumn{2}{|c|}{$\begin{array}{c}\text { CentralPacific region, Japan } \\
\text { (4 sites) }\end{array}$} & LOQ--5.4 & & LOQ—-25 & LOQ-12 & & & $\mathrm{ng} / \mathrm{L}$ & [106] \\
\hline \multicolumn{2}{|c|}{$\begin{array}{l}\text { Greater Pittsburgh area, USA } \\
\text { (6 sites) }\end{array}$} & $2.2-17.3$ & & ND-12 & & & & $\mathrm{ng} / \mathrm{L}$ & [38] \\
\hline \multicolumn{2}{|c|}{$\begin{array}{l}\text { Drinking water from Turia } \\
\text { River Basin, Spain }\end{array}$} & 12 & $<0.3$ & 9 & 28 & & & $\mathrm{ng} / \mathrm{L}$ & [36] \\
\hline \multirow{2}{*}{\multicolumn{2}{|c|}{$\begin{array}{c}\text { Jiulong River Estuary, China } \\
\text { Winter }\end{array}$}} & $2.65-29.1$ & & $1.11-5.22$ & & & & & [82] \\
\hline & & $2.23-53.4$ & & $1.91-68.3$ & & & & $\mathrm{ng} / \mathrm{L}$ & \\
\hline \multicolumn{2}{|c|}{ Spring } & & & & & & & $\mathrm{ng} / \mathrm{L}$ & \\
\hline \multicolumn{2}{|c|}{ Autumn } & $1.41-7.27$ & & $0.4-1.59$ & & & & $\mathrm{ng} / \mathrm{L}$ & \\
\hline \multicolumn{2}{|c|}{ Summer } & $2.98-68.8$ & & $1.06-10.1$ & & & & $\mathrm{ng} / \mathrm{L}$ & \\
\hline \multicolumn{2}{|c|}{ Wet Season } & $1.68-39.4$ & & $3.4-69.9$ & & & & $\mathrm{ng} / \mathrm{L}$ & \\
\hline \multicolumn{2}{|c|}{$\begin{array}{l}\text { Pearl River Estuary, } \\
\text { China (Seawater) }\end{array}$} & 2.21 & 0.94 & 1.12 & 0.21 & 0.01 & 0.04 & $\mathrm{ng} / \mathrm{L}$ & [107] \\
\hline \multicolumn{2}{|c|}{ Florida coast, USA } & $14.7 \pm 10.9$ & $6.12 \pm 7.09$ & $<0.5-9.04$ & & & & & [85] \\
\hline \multicolumn{10}{|c|}{ Concentrations of Parabens in Sediment } \\
\hline \multicolumn{2}{|c|}{ Sampling Area } & MePB & EtPB & PrPB & BuPB & ВеРВ & $n$-PrPB & Unit & Reference \\
\hline \multicolumn{2}{|c|}{ Turia River Basin, Spain } & 476 & 60 & & & & & $\mathrm{ng} / \mathrm{g}$ & [36] \\
\hline \multicolumn{2}{|c|}{ Korea } & $0.13-11.2$ & $<$ LOQ-0.08 & $<$ LOQ-0.10 & $<$ LOQ-0.07 & $<$ LOQ-0.06 & & $\mathrm{ng} / \mathrm{g} d \mathrm{w}$ & [89] \\
\hline \multicolumn{2}{|c|}{ Ebro River, Spain } & $<$ LOQ-435 & $<$ LOQ-2.7 & $<$ LOQ-51 & & & & & \\
\hline \multicolumn{2}{|c|}{ Guadalquivir River, Spain } & $<$ LOQ-63.0 & $<$ LOQ-1.8 & $<$ LOQ-3.5 & & & & $\mathrm{ng} / \mathrm{gdw}$ & [104] \\
\hline \multicolumn{2}{|c|}{ Jucar River, Spain } & $<$ LOQ-22.6 & $<$ LOQ-0.3 & $<$ LOQ-5.3 & & & & & \\
\hline \multicolumn{2}{|c|}{ Llobregat River, Spain } & $<$ LOQ-95 & $<\mathrm{LOQ}-0.91$ & $<$ LOQ-3.9 & & & & & \\
\hline Florid & ist, USA & $0.85-9.00$ & $2.15-12.38$ & & & & & $\mathrm{ng} / \mathrm{g}$ & [91] \\
\hline Tokyc & , Japan & $2.59-17.8$ & $<$ LOQ-0.13 & $<$ LOQ-2.84 & $<$ LOQ-29.1 & $<$ LOQ-0.64 & & $\mathrm{ng} / \mathrm{g}$ & [31] \\
\hline Pearl & r, china & $0.9-8.8$ & & & & & & $\mathrm{ng} / \mathrm{g}$ & [92] \\
\hline Yellow & r, China & $7.07-27.6$ & $0.61-2.43$ & $2.52-6.91$ & $0.96-3.90$ & $0.13-2.09$ & & $\mathrm{ng} / \mathrm{g}$ & [90] \\
\hline Huai & r, China & $6.97-18.8$ & $1.02-2.14$ & $2.72-9.17$ & $1.84-7.6$ & $0.17-0.4$ & & $\mathrm{ng} / \mathrm{g}$ & \\
\hline Guangzh & iver, China & $1.03-69.9$ & $<$ LOQ-1.97 & $<$ LOQ-21.3 & & & & $\mathrm{ng} / \mathrm{g}$ & [93] \\
\hline Dongjiar & ver, China & $1.83-26.2$ & $0.28-0.75$ & $0.16-0.86$ & & & & $\mathrm{ng} / \mathrm{g}$ & [108] \\
\hline Sha $\mathrm{R}$ & China & $1.95-42.8$ & & $0.26-3.19$ & & & & $\mathrm{ng} / \mathrm{g}$ & [109] \\
\hline Yangtze & er, China & $1.43-15.1$ & $<$ LOQ-0.63 & $<$ LOQ-2.40 & & & & $\mathrm{ng} / \mathrm{g}$ & [110] \\
\hline Pearl Rive & uary, China & 118 & 45.4 & 10.0 & 2.09 & 2.75 & 1.07 & $\mathrm{ng} / \mathrm{g}$ & [107] \\
\hline & & & oncentration c & rrabens in Fish & & & & & \\
\hline Sam & g Area & MePB & EtPB & PrPB & BuPB & ВеРВ & $n$-PrPB & Unit & Reference \\
\hline & Mussel & $7 \pm 2$ & $0.3 \pm 0.1$ & & & & $0.56 \pm 0.01$ & & \\
\hline coast of & Manila Clam & $1.6 \pm 0.3$ & & & & & & $\mathrm{ng} / \mathrm{g} d \mathrm{w}$ & [99] \\
\hline & Cockle & $2.0 \pm 0.5$ & $0.37 \pm 0.08$ & & & & & & \\
\hline Manila B & hilippines & & 46.6-195 & $46-1140$ & $6.61-37.3$ & & & $\mathrm{ng} / \mathrm{g}$ lw & [34] \\
\hline $\begin{array}{r}\text { Manila B } \\
\quad(20\end{array}$ & $\begin{array}{l}\text { ish muscle) } \\
\text { cies) }\end{array}$ & $<0.05-3600$ & $<0.011-840$ & $<0.024-1100$ & $<0.003-70$ & & & $\mathrm{ng} / \mathrm{g}$ lw & [35] \\
\hline $\begin{array}{r}\text { Mediterran } \\
\text { (fish } \mathrm{h}\end{array}$ & $\begin{array}{l}\text { Rivers, Spain } \\
\text { genate) }\end{array}$ & $\begin{array}{c}84.69 \pm \\
6.58\end{array}$ & & $0.19 \pm 0.04$ & & & & $\mathrm{ng} / \mathrm{g}$ & [33] \\
\hline
\end{tabular}


Table 1. Cont.

\begin{tabular}{|c|c|c|c|c|c|c|c|c|c|}
\hline \multicolumn{10}{|c|}{ Concentration of Parabens in Fish } \\
\hline \multicolumn{2}{|c|}{ Sampling Area } & МePB & EtPB & PrPB & BuPB & BePB & $n$-PrPB & Unit & Reference \\
\hline \multicolumn{2}{|c|}{$\begin{array}{l}\text { Pearl River Estuary, China } \\
\text { (shellfish and fish) }\end{array}$} & 5.2 & 2.35 & 0.25 & 0.48 & 0.01 & & $\mathrm{ng} / \mathrm{g}$ & [107] \\
\hline \multirow{2}{*}{$\begin{array}{c}\text { Llobregat } \\
\text { River, Spain } \\
\text { (Barbus graellsii) }\end{array}$} & Adult & $\begin{array}{c}62.85 \pm \\
6.52\end{array}$ & & $3.48 \pm 0.58$ & & & & \multirow{2}{*}{$\mathrm{ng} / \mathrm{g} \mathrm{dw}$} & \\
\hline & Juvenile & $\begin{array}{c}33.65 \pm \\
3.70\end{array}$ & & $0.19 \pm 0.04$ & & & & & \\
\hline \multirow{2}{*}{ Cyprinus carpio } & $\begin{array}{c}\text { Llobregat } \\
\text { River, Spain }\end{array}$ & $2.53 \pm 0.38$ & & & & & & \multirow{2}{*}{$\mathrm{ng} / \mathrm{gdw}$} & \\
\hline & $\begin{array}{l}\text { Ebro River, } \\
\text { Spain }\end{array}$ & $3.41 \pm 0.59$ & & & & & & & \\
\hline $\begin{array}{l}\text { Llobregat } \mathrm{R} \\
\quad \text { Lepomis }\end{array}$ & $\begin{array}{l}\text { er, Spain } \\
\text { bosus) }\end{array}$ & $9.08 \pm 1.06$ & & $0.64 \pm 0.13$ & & $0.35 \pm 0.02$ & & $\mathrm{ng} / \mathrm{g} \mathrm{dw}$ & [33] \\
\hline \multirow{4}{*}{$\begin{array}{l}\text { Jucar River, } \\
\text { Spain }\end{array}$} & Salmo truta & $4.45 \pm 0.44$ & $\begin{array}{l}0.82 \text { (Adult) } \\
0.78 \text { (Juvenile) }\end{array}$ & $1.43 \pm 0.69$ & & & & \multirow{4}{*}{$\mathrm{ng} / \mathrm{g} d \mathrm{w}$} & \\
\hline & $\begin{array}{l}\text { Micropterus } \\
\text { salmoides }\end{array}$ & $4.45 \pm 0.44$ & & & & & & & \\
\hline & $\begin{array}{l}\text { Anguilla } \\
\text { anguilla }\end{array}$ & $2.97 \pm 0.13$ & & & & $0.50 \pm 0.04$ & & & \\
\hline & $\begin{array}{l}\text { Lepomis } \\
\text { gibbosus }\end{array}$ & & & & & 0.54 & & & \\
\hline \multicolumn{2}{|c|}{ Sampling Area } & МePB & EtPB & PrPB & BuPB & ВеPB & $n$-PrPB & Unit & Reference \\
\hline \multicolumn{2}{|c|}{$\begin{array}{l}\text { Urinary concentration of } \\
\text { parabens in U.S population } \\
\text { ( } \geq 6 \text { years) }\end{array}$} & $5.60-974$ & ND-57.2 & $0.30-299$ & ND-19.6 & & & $\mu \mathrm{g} / \mathrm{L}$ & [111] \\
\hline \multirow[t]{2}{*}{ Spain } & $\begin{array}{l}\text { Pregnant } \\
\text { Women }\end{array}$ & 100 & 98 & 88 & 90 & & & $\mathrm{ng} / \mathrm{L}$ & [112] \\
\hline & Children & 100 & 100 & 80 & 83 & & & $\mathrm{ng} / \mathrm{L}$ & \\
\hline \multicolumn{2}{|c|}{ Newborn infants, Korea } & 79.6 & 2.4 & 3.4 & & & & $\mu \mathrm{g} / \mathrm{L}$ & [30] \\
\hline \multicolumn{2}{|c|}{ Serum level in Danish women } & ND-59.6 & ND-20.8 & ND-5.50 & ND-0.87 & ND-0.29 & & $\mathrm{ng} / \mathrm{L}$ & [113] \\
\hline \multicolumn{2}{|c|}{$\begin{array}{l}\text { Breast milk (28-40-year-old } \\
\text { women) (Valencian } \\
\text { region, Spain) }\end{array}$} & $0.11-7.00$ & $0.49-4.05$ & $0.13-0.76$ & $0.17-0.34$ & & & $\mathrm{ng} / \mathrm{mL}$ & [114] \\
\hline \multicolumn{2}{|c|}{ Breast milk, North Carolina } & $0.5-21$ & & $0.1-12$ & & & & $\mathrm{ng} / \mathrm{mL}$ & [115-117] \\
\hline \multicolumn{2}{|c|}{ Breast milk, Spain } & & $0.6-22$ & & $0.81-1.10$ & & & $\mathrm{ng} / \mathrm{mL}$ & [118] \\
\hline \multicolumn{2}{|c|}{$\begin{array}{c}\text { The Belgian } \\
\text { ENVIRONAGE cohort } \\
\text { (placenta samples) }\end{array}$} & $0.5-7.1$ & $0.5-4.5$ & $0.5-9.1$ & & & & $\mathrm{ng} / \mathrm{g}$ & [119] \\
\hline \multicolumn{2}{|c|}{$\begin{array}{l}\text { Hospital Sant Joan de Deu, } \\
\text { Barcelona, Spain (mothers at } \\
\text { first trimester) }\end{array}$} & 11.77 & & & & & & $\begin{array}{l}\mathrm{ng} / \mathrm{g} \mathrm{fw} \\
\text { (fresh } \\
\text { weight) }\end{array}$ & [120] \\
\hline \multirow{2}{*}{ Taiwan (urine) } & Male & ND-56.8 & ND-52.0 & ND-1.8 & ND-19.5 & & & \multirow{2}{*}{$\mathrm{ng} / \mathrm{mL}$} & \multirow{2}{*}{ [121] } \\
\hline & Female & ND-174 & ND-40.4 & ND-61.4 & ND-84.7 & & & & \\
\hline
\end{tabular}

\subsection{Phenols in Water}

Widespread use of phenols in industry and agricultural and consumer products has resulted in environmental contamination. Bisphenol A (BPA) and its analogues (BPF, BPS, BPAF, and BPB) and alkyl phenols (octyl (OP)- and nonyl-phenols (NP)) are widespread micropollutants in the global environment and are considered potent endocrine disruptors. [45]. Occurrence of residues of these compounds in environmental media (air, water, soil, sediment, etc.) and biota (fish and other organisms, including human tissues) were reported widely (Table 2). Literature dealing with contamination profiles of these compounds in water, soil/sediment, and biota (fish and human tissue) are reviewed and environmental and health implications are explored in this section. Environmental contamination levels of these compounds vary in different countries depending on the usage pattern, treatment, disposal, and recalcitrant properties (chemical characteristics). Indiscriminate use and disposal of materials containing phenols contaminate rivers, lakes, and coastal waters. BPA contamination levels in the Jiulong River estuary (China) and Tokyo Bay 
(Japan) were $364 \mathrm{ng} / \mathrm{L}$ and $431 \mathrm{ng} / \mathrm{L}$, respectively [54,82] (Table 2). Liu et al. [122] and Basheer et al. [123] reported BPA in Laizhou Bay (China) (11.1-101 ng/L) and in the coastal waters of Singapore $(<1.1 \mathrm{ng} / \mathrm{L})$. Bisphenol analogues were common contaminants in the Pearl River estuary, South China. Zhao et al. reported $35 \mathrm{ng} / \mathrm{L}$ and $24.6 \mathrm{ng} / \mathrm{L}$ (median concentrations) of BPF and BPA, respectively, and a comparatively low (median) concentration $(0.41 \mathrm{ng} / \mathrm{L})$ of BBP in this estuary [107]. Large-scale (206,000 tons of BPA/year) production and widespread use/application (by a huge population) resulted in higher contamination of BPA and BPF around the Pearl River estuary [124]. Contamination with BPA in water samples from different geographical regions was reported, including the Baltic Sea (Germany), the sea of Ria de Aveiro (Portugal), and Ross Island (Antarctica). BPA and BPF were the predominant BPA analogues in seawater and other matrices, including surface water, sewage effluent, sewage sludge, and sediment [82,84]. BPA concentrations in estuarine water samples from Pulao Kukup, Johor, Malaysia, ranged from 0.19 to $0.47 \mathrm{ng} / \mathrm{L}$ [125], and were lower than in surface river water from the Han River, Seoul, South Korea (6.90-59 $\mathrm{ng} / \mathrm{L})$ [126]. Wee et al. [127] reported the contamination of surface water by BPA in the Langat River, Malaysia. Industrial and municipal WWTPs were the most important sources of BPA in drinking water sources of Malaysia (215 ng/L) [128]. An investigation of BPA and alkylphenols levels in mariculture fish species by Ismail et al. showed a wide range of contaminations of these compounds in Malaysian mariculture production, and the concentrations BPA in fish muscle ranged between 0.023 and $0.322 \mathrm{ng} / \mathrm{g}$ [129].

A study conducted by Pignotti and Dinelli in northeastern part of Italy [130] found wide ranges of BPA ( $<\mathrm{LOQ}-244 \mathrm{ng} / \mathrm{L})$ and $\mathrm{NP}(\mathrm{LOQ}-135 \mathrm{ng} / \mathrm{L})$ in the main rivers of the Romagna area. The Fiumi Uniti River had been mostly contaminated by NP (135 ng/L) due to presence of a point source for NP in Fiumi Uniti [130]. Octyl and nonylphenols are not separated in conventional WWTPs, hence these compounds contaminate receiving water sources and other environmental matrices [131]. Wang et al. [132] found NP in reclaimed, surface, and ground waters from a southeastern suburb of Beijing, China. The NP in the ground and surface waters ranged from ND-1047.9 ng/L and 357.6 to $1260.9 \mathrm{ng} / \mathrm{L}$, respectively. Variations in NP concentration among aquifers may be due to sewage penetration history and water sources of aquifer recharge. The NP concentration in ground water was decreased with increasing aquifer depth.

\subsection{Phenols in Soil/Sediment}

Sediments serve as the main sink for hydrophobic organic chemicals because of their hydrophobicity and high $\log \mathrm{K}_{\text {ow }}$ values (3.43 and 5.76) [133]. Many researchers have focused on the emerging contaminants in sediments [46], which are presented in Table 2. BPA was frequently found in sediment samples from the Turia River, Spain [134]. Zhang et al. reported nonylphenol (12.9 to $1159.9 \mathrm{ng} / \mathrm{g} \mathrm{dw}$ ) and octylphenol (1.3 to $13.6 \mathrm{ng} / \mathrm{g} \mathrm{dw}$ ) in Xiamen Bay sediments in China [135]. Pignotti and Dinelli [130] found residues of BPA and $\mathrm{NP}$ in water and sediment samples from several rivers in northern Italy. They found very low ranges of BPA $(<\mathrm{LOQ}-1.9 \mathrm{ng} / \mathrm{g} \mathrm{dw})$ and NP $(<\mathrm{LOQ}-7.6 \mathrm{ng} / \mathrm{g} \mathrm{dw})$ in core sediments from the Fiumi Uniti River. The NP concentrations in Savio River sediments ranged from 8.6 to $32 \mathrm{ng} / \mathrm{g} \mathrm{dw}$. Contamination levels of BPA and NP were reported in various countries, including the Pearl River catchment, China (BPA: 2.54-269 ng/g dw, NP: 10.9-14400 ng/g dw), San Francisco Bay (USA) (NP: 21.5-86.3 ng/g dw), and U.S. rivers (BPA: $<0.25-106 \mathrm{ng} / \mathrm{g} \mathrm{dw}$ ) [92,136]. Gorga et al. [104] found the highest NP concentration in sediments from the Iberian peninsula (Ebro River) $(<1.6-1693 \mathrm{ng} / \mathrm{g} \mathrm{dw})$, followed by Llbregat River (19-470 ng/g dw), Jucar River ( $<1.6-175$ ng/g dw) and Guadalquivir River (61-190 ng/g dw).

Sludges from different WWTPs are used in agricultural fields to enrich organic matter, and hence agricultural soils treated with sludge were found with NP, OP, AEOs, and APEOs. Andreu et al. [137] analyzed WWTP sewage-sludge-amended forest soils (located in the 21 Valencian Community, Mediterranean Rendizic Leptosol), and reported the highest NP concentration of $500 \mu \mathrm{g} / \mathrm{kg}$, followed by OPEOs $(369 \mu \mathrm{g} / \mathrm{kg})$ and NPEOs $(329 \mu \mathrm{g} / \mathrm{kg})$. 
The reported OPEOs and NPEOs found in the soils were mainly composed of mono-, di-, ti-, tetra-, and pentaethoxylates. The highest contamination level of phenols were found in the soil samples treated with sludge from WWTPs that receive industrial effluents, whereas sludge from WWTPs from domestic and industrial wastewater (tanneries and textile industry) showed lower levels of phenols in soil samples [137].

\subsection{Phenols in Biota/Fish}

Phenol concentrations found in fish are given in Table 2. Alkylphenols (APs) are used in surfactants, which ultimately end up in the aquatic and terrestrial environments through discharges from manufacturing facilities and WWTPs [138]. Exposure to 4-nonylphenol (4NP) led to behavioral changes in salmon fish [139]. Zhao et al. [107] found bisphenols (41.6 ng/g) and BPP (median concentration: $25.4 \mathrm{ng} / \mathrm{g}$ ) in fish from the Pearl River estuary, South China. Gonads were detected with a higher BPA concentration and detection frequency (ND-138 ng/g) than in liver (ND-61.9 ng/g). Fish samples from the Turia River were frequently detected with BPA (33 ng/g) [134]. BPA concentration in fish species from the Xiangiiang River were comparable to other locations, including the Yundang Lagoon, China (54.2-177 ng/g); the Anzali Wetland, Iran; and the Basque Coast, Spain (20-97 ng/g). The BPA concentration was higher in the liver than that of gill and muscle $[140,141]$. The Pearl River basin has been contaminated with several EDCs (BPA, 4-t-OP, 4-NP, etc.), which were detected in the surface water and fish tissues [142]. Environmental exposure concentrations could affect the accumulation of EDCs in fish [143]. 4- $n$-NP and BPA were found in tissues (muscle, liver, gill, and other tissues) of three freshwater fish species (Parabramis pekinensis, Cyprinus carpio and Siniperca chuatsi) from the Xiangjiang River, Southern China. The 4- $n$-NP was at the highest average concentration in liver, because accumulation, biotransformation, and excretion of EDCs in liver have been crucial, although the presence of $4-n-\mathrm{NP}$ and BPA in all four tissues implied the bioaccumulation ability of these compounds in fish [144]. EDC exposure levels were attributed to different seasons, as liver samples were observed with higher 4-t-OP and 4-NP during the wet season compared to dry season, whereas in plasma lower BPA and higher 4-t-OP were observed in the wet season. In contrast to liver and plasma, BPA and $4-t$-OP concentrations in muscle were more in the dry season than in the wet season.

Considering the sources of phenolic compounds in biota, the Pulau Kukup (Johor) has been dominated by industrial and mariculture activities, which mainly release BPA and APs [129]. The major sources for BPA and APs in mariculture are plastic wastes, landfill wastes, treatment plant effluents, industrial discharges, and cleaning products from surrounding industries located near the mariculture cages at Pulau Kukup. These factors may be attributable to higher BPA and AP accumulations in fish [145]. Three different mariculture fish species (Trachinotus blochii (golden pomfret), Lutjanus campechanus (snapper), and Lates calcarifer (sea bass)) were analyzed to evaluate BPA, 4OP, and 4NP contamination. BPA was detected in all fish species, but APs were detected in Trachinotus blochii. Trachinotus blochii $(0.322 \mathrm{ng} / \mathrm{g}$ ) had the highest BPA concentration, followed by Lutjanus campechanus $(0.084 \mathrm{ng} / \mathrm{g}$ ) and Lates calcarifer $(0.078 \mathrm{ng} / \mathrm{g})$. Likewise, $4 \mathrm{OP}$ and $4 \mathrm{NP}$ were found to be lower in Trachinotus sp., at $0.023 \mathrm{ng} / \mathrm{g}$ and $0.124 \mathrm{ng} / \mathrm{g}$, respectively [129].

While some of the mechanisms (biliary excretion) in the body eliminate APs, humans are the final consumers who accumulate the highest level of contaminants [145]. Therefore, continued biomonitoring of phenolic EDCs is indispensable to prevent human exposure and health implications. 
Table 2. Phenolic compounds in environmental matrices and human samples.

\begin{tabular}{|c|c|c|c|c|}
\hline \multicolumn{5}{|c|}{ Concentration of Phenolic Compounds in Water } \\
\hline Sampling Area & Compound & Concentration & Unit & Reference \\
\hline \multirow{6}{*}{ Manzanares River, Spain } & BPA & $\begin{array}{l}36.5 \text { (Sunday) } \\
37 \text { (Thursday) }\end{array}$ & \multirow{10}{*}{$\mathrm{ng} / \mathrm{L}$} & \multirow{10}{*}{ [103] } \\
\hline & $\mathrm{OP}$ & $\begin{array}{l}109.5 \text { (Sunday) } \\
125 \text { (Thursday) }\end{array}$ & & \\
\hline & NP & $\begin{array}{c}850 \text { (Sunday) } \\
622.5 \text { (Thursday) }\end{array}$ & & \\
\hline & Nonylphenolmonocarboxylate & $\begin{array}{l}1342.5 \text { (Sunday) } \\
938 \text { (Thursday) }\end{array}$ & & \\
\hline & Octylphenoldiethoxylate & $\begin{array}{c}46.5 \text { (Sunday) } \\
15.5 \text { (Thursday) }\end{array}$ & & \\
\hline & Nonylphenoldiethoxylate & $\begin{array}{l}279.5 \text { (Sunday) } \\
168 \text { (Thursday) }\end{array}$ & & \\
\hline \multirow{6}{*}{ Jarama River, Spain } & $\mathrm{BPA}$ & $\begin{array}{c}106 \text { (Sunday) } \\
47.5 \text { (Thursday) }\end{array}$ & & \\
\hline & OP & $\begin{array}{c}60 \text { (Sunday) } \\
96 \text { (Thursday) }\end{array}$ & & \\
\hline & NP & $\begin{array}{c}123 \text { (Sunday) } \\
813 \text { (Thursday) }\end{array}$ & & \\
\hline & Nonylphenolmonocarboxylate & $\begin{array}{l}734 \text { (Sunday) } \\
926 \text { (Thursday) }\end{array}$ & & \\
\hline & Octylphenoldiethoxylate & $\begin{array}{c}68 \text { (Sunday) } \\
49 \text { (Thursday) }\end{array}$ & & \\
\hline & Nonylphenoldiethoxylate & $\begin{array}{l}345 \text { (Sunday) } \\
637 \text { (Thursday) }\end{array}$ & & \\
\hline Llobregat River and other rivers of Spain & BPA & 2970 & $\mathrm{ng} / \mathrm{L}$ & [146-148] \\
\hline Jialu River, China & \multirow{3}{*}{ BPA } & 2990 & $\mathrm{ng} / \mathrm{L}$ & [149] \\
\hline Liao River and Yellow River, China & & 755.6 & $\mathrm{ng} / \mathrm{L}$ & [150] \\
\hline Rio das Velhas River, Brazil & & 168.3 & $\mathrm{ng} / \mathrm{L}$ & [151] \\
\hline Qiantang River and Tiesha River & \multirow{3}{*}{ NP } & 8540 & $\mathrm{ng} / \mathrm{L}$ & [152] \\
\hline Rio das Velhas River, Brazil & & 1582 & $\mathrm{ng} / \mathrm{L}$ & [151] \\
\hline Liao River and Yellow River, China & & 2065.7 & $\mathrm{ng} / \mathrm{L}$ & [150] \\
\hline Liao River and Yellow River, China & \multirow{5}{*}{ OP } & 577.9 & $\mathrm{ng} / \mathrm{L}$ & [150] \\
\hline Llobregat River and other rivers of Spain & & 6200 & $\mathrm{ng} / \mathrm{L}$ & [146-148] \\
\hline Jialu River, China & & 63.2 & $\mathrm{ng} / \mathrm{L}$ & [153] \\
\hline Liao River and Yellow River, China & & 52.1 & $\mathrm{ng} / \mathrm{L}$ & [150] \\
\hline Rio das Velhas River, Brazil & & 1435 & $\mathrm{ng} / \mathrm{L}$ & [151] \\
\hline \multirow{2}{*}{ Northern Antarctic Peninsula region } & BPA & 18.74 & \multirow{2}{*}{$\mathrm{ng} / \mathrm{L}$} & \multirow{2}{*}{ [154] } \\
\hline & NP & 138.32 & & \\
\hline Mississippi & BPA & 57.14 & $\mathrm{ng} / \mathrm{L}$ & [155] \\
\hline Rivers in Portugal & BPA & 5.4 & $\mathrm{ng} / \mathrm{L}$ & [24] \\
\hline PulauKukup, Johor (estuarine water) & BPA & $0.19-0.47$ & $\mathrm{ng} / \mathrm{L}$ & [125] \\
\hline \multirow{2}{*}{$\begin{array}{l}\text { Seoul, } \\
\text { South Korea }\end{array}$} & \multirow{2}{*}{ BPA } & $6.90-59.00$ & $\mathrm{ng} / \mathrm{L}$ & \multirow{2}{*}{ [126] } \\
\hline & & 5.00-1918 & $\mathrm{ng} / \mathrm{L}$ & \\
\hline
\end{tabular}


Table 2. Cont.

\begin{tabular}{|c|c|c|c|c|}
\hline \multicolumn{5}{|c|}{ Concentration of Phenolic Compounds in Water } \\
\hline Sampling Area & Compound & Concentration & Unit & Reference \\
\hline Xiangjiang River & \multirow{4}{*}{ Alkylphenol } & $0.79-3079.4$ & $\mathrm{ng} / \mathrm{L}$ & [156] \\
\hline Pearl River, China & & $8-15688$ & $\mathrm{ng} / \mathrm{L}$ & [157] \\
\hline Han River, South Korea & & $6.9-5.9$ & $\mathrm{ng} / \mathrm{L}$ & [126] \\
\hline Rio de Janeiro, Brazil & & $204-13016$ & $\mathrm{ng} / \mathrm{L}$ & [158] \\
\hline \multirow{3}{*}{ Iberian River, Spain } & BPA & ND-649 & $\mathrm{ng} / \mathrm{L}$ & \multirow{3}{*}{ [104] } \\
\hline & OP & ND-85 & $\mathrm{ng} / \mathrm{L}$ & \\
\hline & NP & ND-391 & $\mathrm{ng} / \mathrm{L}$ & \\
\hline \multirow{2}{*}{ Lamone River, northeastern part of Italy } & $\mathrm{BPA}$ & 16 & \multirow{2}{*}{$\mathrm{ng} / \mathrm{L}$} & \multirow{10}{*}{ [130] } \\
\hline & NP & 39 & & \\
\hline \multirow{2}{*}{ Fiumi Uniti River, Italy } & $\mathrm{BPA}$ & 19 & \multirow{2}{*}{$\mathrm{ng} / \mathrm{L}$} & \\
\hline & $\mathrm{NP}$ & 94 & & \\
\hline \multirow{2}{*}{ Bevano River, Italy } & $\mathrm{BPA}$ & 46 & \multirow{2}{*}{$\mathrm{ng} / \mathrm{L}$} & \\
\hline & NP & 41 & & \\
\hline \multirow{2}{*}{ Savio River, Italy } & BPA & 23 & \multirow{2}{*}{$\mathrm{ng} / \mathrm{L}$} & \\
\hline & $\mathrm{NP}$ & 79 & & \\
\hline \multirow{2}{*}{ Marecchia River, Italy } & BPA & 195 & \multirow{2}{*}{$\mathrm{ng} / \mathrm{L}$} & \\
\hline & $\mathrm{NP}$ & 9.7 & & \\
\hline Guangzhou tap water & $\mathrm{BPA}$ & 317 & & [159] \\
\hline Langat River, Peninsular, Malaysia & BPA & $1.18-8.24$ & $\mathrm{ng} / \mathrm{L}$ & [127] \\
\hline Malaysia (drinking water sources) & BPA & ND-215 & $\mathrm{ng} / \mathrm{L}$ & [128] \\
\hline Jiulong River Estuary, China & BPA & ND-364 & $\mathrm{ng} / \mathrm{L}$ & [82] \\
\hline \multirow{2}{*}{ Tokyo Bay, Japan } & $\mathrm{BPA}$ & ND-431 & \multirow{2}{*}{$\mathrm{ng} / \mathrm{L}$} & \multirow{2}{*}{ [54] } \\
\hline & $\mathrm{BPF}$ & ND-1470 & & \\
\hline Pearl River Estuary, China & BPA & 24.6 & $\mathrm{ng} / \mathrm{L}$ & [107] \\
\hline Ria de Aveiro, Portugal & BPA & $<1.1$ & $\mathrm{ng} / \mathrm{L}$ & [24] \\
\hline Ross Island, Antarctic & BPA & $<1.3-7.7$ & $\mathrm{ng} / \mathrm{L}$ & [84] \\
\hline Laizhou Bay, China & BPA & $11.1-101$ & & [122] \\
\hline \multirow{3}{*}{ Pearl River, China } & 4-NP & $61-2996$ & \multirow{3}{*}{$\mathrm{ng} / \mathrm{L}$} & \multirow{3}{*}{ [160] } \\
\hline & $4-\mathrm{t}-\mathrm{OP}$ & ND-198 & & \\
\hline & BPA & $66-556$ & & \\
\hline \multirow{3}{*}{ The Pearl River Delta region, China } & $\mathrm{BPA}$ & $5.84-469$ & \multirow{3}{*}{$\mathrm{ng} / \mathrm{L}$} & \multirow{3}{*}{ [143] } \\
\hline & $4-\mathrm{NP}$ & $52.0-8643$ & & \\
\hline & $4-\mathrm{t}-\mathrm{OP}$ & 1539 & & \\
\hline \multirow{2}{*}{ Gernika } & $4-\mathrm{t}-\mathrm{OP}$ & $41 \pm 2$ & \multirow{3}{*}{$\mathrm{ng} / \mathrm{L}$} & \multirow{3}{*}{ [161] } \\
\hline & $4 \mathrm{nOP}$ & $22 \pm 2$ & & \\
\hline Santurtzi & $4-\mathrm{t}-\mathrm{OP}$ & $17 \pm 2$ & & \\
\hline
\end{tabular}


Table 2. Cont.

\begin{tabular}{|c|c|c|c|c|}
\hline \multicolumn{5}{|c|}{ Concentration of Phenolic Compounds in Water } \\
\hline Sampling Area & Compound & Concentration & Unit & Reference \\
\hline \multirow{3}{*}{$\begin{array}{l}\text { Cangzhou, Hebei, China (irrigation with } \\
\text { ground water) }\end{array}$} & $4-\mathrm{t}-\mathrm{OP}$ & $6.8 \pm 2.1$ & \multirow{9}{*}{$\mathrm{ng} / \mathrm{L}$} & \multirow{9}{*}{ [162] } \\
\hline & $4 \mathrm{nOP}$ & $350 \pm 37.2$ & & \\
\hline & $\mathrm{BPA}$ & $61.2 \pm 5.2$ & & \\
\hline \multirow{3}{*}{$\begin{array}{l}\text { Shijazhuang, Heibei, China (irrigation with } \\
\text { ground water) }\end{array}$} & $4-\mathrm{t}-\mathrm{OP}$ & $9.0 \pm 1.4$ & & \\
\hline & $4 \mathrm{nOP}$ & $396 \pm 51.2$ & & \\
\hline & BPA & $51.7 \pm 2.9$ & & \\
\hline \multirow{3}{*}{$\begin{array}{l}\text { Baoding, Heibei, China (irrigation with } \\
\text { ground water) }\end{array}$} & $4-\mathrm{t}-\mathrm{OP}$ & $5.2 \pm 0.66$ & & \\
\hline & $4 \mathrm{nOP}$ & $202 \pm 69.6$ & & \\
\hline & BPA & $44.8 \pm 2.8$ & & \\
\hline \multicolumn{5}{|c|}{ Concentration of Phenolic Compounds in Sediments } \\
\hline Sampling Area & Compound & Concentration & Unit & Reference \\
\hline \multirow{5}{*}{ Pearl River estuary, China } & BPA & 69.4 & \multirow{5}{*}{$\mathrm{ng} / \mathrm{g}$} & \multirow{5}{*}{ [107] } \\
\hline & BPS & 41.6 & & \\
\hline & $\mathrm{BPF}$ & 183 & & \\
\hline & BPAF & 167 & & \\
\hline & $\mathrm{BPB}$ & 73.3 & & \\
\hline \multirow{3}{*}{ Pearl River, China } & BPA & $7.3-627$ & \multirow{3}{*}{$\mathrm{ng} / \mathrm{g}$} & \multirow{3}{*}{ [160] } \\
\hline & 4-NP & $53-12042$ & & \\
\hline & $4-\mathrm{t}-\mathrm{OP}$ & $8.3-176$ & & \\
\hline \multicolumn{5}{|c|}{ Concentration of Phenolic Compounds in Fish } \\
\hline Sampling Area & Compound & Concentration & Unit & Reference \\
\hline \multirow{5}{*}{$\begin{array}{l}\text { Mariculture production, Malaysia } \\
\text { (fish muscle) }\end{array}$} & BPA & $0.023-0.322$ & \multirow{5}{*}{$\mathrm{ng} / \mathrm{g}$} & \multirow{5}{*}{ [129] } \\
\hline & BPS & 10.3 & & \\
\hline & $\mathrm{BPF}$ & 35.0 & & \\
\hline & BPAF & 0.70 & & \\
\hline & BPB & 1.51 & & \\
\hline \multirow{6}{*}{ Pearl River estuary, China (shellfish and fish) } & $\mathrm{BPP}$ & 25.4 & \multirow{6}{*}{$\mathrm{ng} / \mathrm{mL}$} & \multirow{6}{*}{ [107] } \\
\hline & BPA & 0.81 & & \\
\hline & BPS & 1.27 & & \\
\hline & $\mathrm{BPF}$ & 1.45 & & \\
\hline & BPAF & 0.22 & & \\
\hline & $\mathrm{BPB}$ & 12.3 & & \\
\hline $\begin{array}{l}\text { Llobregat River, Spain } \\
\text { (Barbusgraellsii) }\end{array}$ & BPA & $223.91 \pm 11.51$ & \multirow{2}{*}{$\mathrm{ng} / \mathrm{g} d w$} & \multirow{2}{*}{ [33] } \\
\hline $\begin{array}{l}\text { Guadalquivir River, Spain } \\
\text { (luciobarbuss clateri) }\end{array}$ & BPA & $59.09 \pm 8.12$ & & \\
\hline
\end{tabular}


Table 2. Cont.

\begin{tabular}{|c|c|c|c|c|c|c|}
\hline \multicolumn{7}{|c|}{ Concentration of Phenolic Compounds in Fish } \\
\hline \multicolumn{2}{|c|}{ Sampling Area } & \multirow[t]{2}{*}{ Compound } & \multicolumn{2}{|c|}{ Concentration } & \multirow[t]{2}{*}{ Unit } & \multirow[t]{2}{*}{ Reference } \\
\hline \multirow{13}{*}{$\begin{array}{l}\text { Pearl River delta } \\
\text { region (the } \\
\text { Dongjang River, } \\
\text { Shima River, } \\
\text { Danshui River, } \\
\text { and } \\
\text { Xizhijiang River) }\end{array}$} & & & Wet season & Dry season & & \\
\hline & \multirow{3}{*}{ Bile } & BPA & $2.45-1,3610$ & $0-1,3070$ & \multirow{12}{*}{$\mathrm{ng} / \mathrm{g} w \mathrm{w}$} & \multirow{12}{*}{ [143] } \\
\hline & & $4-\mathrm{t}-\mathrm{OP}$ & 38.6-1938 & $35.9-2625$ & & \\
\hline & & $4-\mathrm{NP}$ & $4695-21160$ & $3216-27420$ & & \\
\hline & \multirow{3}{*}{ Liver } & BPA & $2.17-40920$ & $1.27-16070$ & & \\
\hline & & $4-\mathrm{t}-\mathrm{OP}$ & $0-261$ & $0-50.8$ & & \\
\hline & & 4-NP & $0-5978$ & $0-3535$ & & \\
\hline & \multirow{3}{*}{ Plasma } & BPA & $6.90-141$ & $8.51-1571$ & & \\
\hline & & $4-\mathrm{t}-\mathrm{OP}$ & $26.7-135$ & $31.2-56.0$ & & \\
\hline & & $4-\mathrm{NP}$ & $2743-5530$ & $3136-5901$ & & \\
\hline & \multirow{3}{*}{ Muscle } & BPA & $3.76-65.5$ & $0.70-2053$ & & \\
\hline & & $4-\mathrm{t}-\mathrm{OP}$ & $0-4.53$ & $0-6.98$ & & \\
\hline & & $4-\mathrm{NP}$ & $9.54-307$ & $14.2-329$ & & \\
\hline \multirow{8}{*}{$\begin{array}{c}\text { Xiangjang River, } \\
\text { China } \\
\text { (Parabramis } \\
\text { pekinensis, } \\
\text { Cyprinus carpio, } \\
\text { Siniperca chuatsi) }\end{array}$} & \multirow{2}{*}{ Muscle } & $4-n-\mathrm{NP}$ & \multicolumn{2}{|c|}{ ND-2.07 } & \multirow{8}{*}{$\mathrm{ng} / \mathrm{g}$} & \multirow{8}{*}{ [121] } \\
\hline & & $\mathrm{BPA}$ & \multicolumn{2}{|c|}{ ND-3.51 } & & \\
\hline & \multirow{2}{*}{ Liver } & $4-n-\mathrm{NP}$ & \multicolumn{2}{|c|}{ ND-148 } & & \\
\hline & & BPA & \multicolumn{2}{|c|}{ ND-61.9 } & & \\
\hline & \multirow{2}{*}{ Gill } & $4-n-\mathrm{NP}$ & \multicolumn{2}{|c|}{ ND-29.7 } & & \\
\hline & & $\mathrm{BPA}$ & \multicolumn{2}{|c|}{ ND-48.2 } & & \\
\hline & Gonad & $4-n-\mathrm{NP}$ & & & & \\
\hline & & BPA & & & & \\
\hline $\begin{array}{l}\text { Pearl River } \\
\text { estuary, China }\end{array}$ & Mugilcephalus & BPA & & & $\mathrm{ng} / \mathrm{gdw}$ & [163] \\
\hline (muscle tissue) & Parabramispekinensis & BPA & & & & \\
\hline $\begin{array}{c}\text { Loma Lake, } \\
\text { China (Grass carp } \\
\text { and Lateolabrax } \\
\text { japonicas) }\end{array}$ & Muscle & BPA & & & $n g / g d w$ & [164] \\
\hline $\begin{array}{l}\text { Northern coast of } \\
\text { Sicily, Italy }\end{array}$ & Muscle & BPA & & & $\mathrm{ng} / \mathrm{g}$ & [140] \\
\hline (Red mullet) & Liver & BPA & & & & \\
\hline $\begin{array}{l}\text { Panlong River, } \\
\text { Chin (Crucian }\end{array}$ & Muscle & BPA & & & $\mathrm{ng} / \mathrm{g}$ & [144] \\
\hline carp and carp) & Gill & BPA & & & & \\
\hline Basque coast, & Muscle & BPA & & & & \\
\hline $\begin{array}{l}\text { Spain } \\
\text { (Grev mullet) }\end{array}$ & Liver & BPA & & & $\mathrm{ng} / \mathrm{g}$ & [141] \\
\hline & Brain & BPA & & & & \\
\hline Taihu Lake, China & Muscle & BPA & & & $\mathrm{ng} / \mathrm{g}$ & [132] \\
\hline $\begin{array}{l}\text { Pearl River delta, } \\
\text { China (Carp) }\end{array}$ & Bile & BPA & & & $\mathrm{ng} / \mathrm{g}$ & [165] \\
\hline & Barbel & & & & & \\
\hline Rhone River, & Common bream & BPA & & & $\mathrm{ng} / \mathrm{g}$ & [166] \\
\hline France & White bream & & & & & \\
\hline & Chub & & & & & \\
\hline & Muscle & BPA & & & & {$[167]$} \\
\hline (Cyprinus carpio) & Liver & & & & mg/g & {$[10 /]$} \\
\hline
\end{tabular}


Table 2. Cont.

\begin{tabular}{|c|c|c|c|c|c|}
\hline \multicolumn{6}{|c|}{ Concentration of Phenolic Compounds in Fish } \\
\hline \multicolumn{2}{|c|}{ Sampling Area } & Compound & Concentration & Unit & Reference \\
\hline \multirow{3}{*}{$\begin{array}{l}\text { Dianchi Lake, } \\
\text { China (Crucian } \\
\text { carp and carp) }\end{array}$} & Muscle & \multirow{3}{*}{ BPA } & 38.7 & \multirow{3}{*}{$\mathrm{ng} / \mathrm{g}$} & \multirow{3}{*}{ [168] } \\
\hline & Liver & & 107 & & \\
\hline & Gill & & 37.5 & & \\
\hline \multicolumn{6}{|c|}{ Concentration of Phenolic Compounds in Human Samples } \\
\hline \multicolumn{2}{|c|}{ Sampling Area } & Compound & Concentration & Unit & Reference \\
\hline \multirow{3}{*}{\multicolumn{2}{|c|}{$\begin{array}{c}\text { Valencian region, Spain (28-40-year-old } \\
\text { women's breast milk) }\end{array}$}} & $\mathrm{BPF}$ & $0.13-0.32$ & \multirow{3}{*}{$\mathrm{ng} / \mathrm{mL}$} & \multirow{3}{*}{ [114] } \\
\hline & & BPS & $<$ LOQ-0.37 & & \\
\hline & & BPA & $<$ LOQ-1.62 & & \\
\hline \multirow{4}{*}{\multicolumn{2}{|c|}{$\begin{array}{l}\text { The Belgian ENVIRONAGE cohort } \\
\text { (placenta samples) }\end{array}$}} & BPA & $0.5-3.9$ & \multirow{4}{*}{$\mathrm{ng} / \mathrm{g}$} & \multirow{4}{*}{ [119] } \\
\hline & & $\mathrm{BPF}$ & $0.6-2.1$ & & \\
\hline & & BPS & $0.8-1.3$ & & \\
\hline & & OP & $0.5-3.7$ & & \\
\hline
\end{tabular}

\subsection{Phthalates in Water}

Phthalate contamination in water samples from different countries is presented in Table 3. The highest levels of low molecular weight phthalates (DBP) and high molecular weight phthalates (DEHP) were predominantly detected in drinking water sources in Northeast China ( $4498.2 \mathrm{ng} / \mathrm{L}$ and $6570.9 \mathrm{ng} / \mathrm{L}$, respectively). The diminished removal rate of phthalates during drinking water supply purification leads to potential health risks in Northeast China, as well as in other countries [122]. In China, PAE concentrations in water ranged from $0.47 \mu \mathrm{g} / \mathrm{L}$ to $118.25 \mu \mathrm{g} / \mathrm{L}[169,170]$. Gao et al. [171] reported the highest total PAE concentrations in rivers around Taihu Lake. The authors detected various phthalates, including BBP $(3.58 \mu \mathrm{g} / \mathrm{L})$, DEP $(4.79 \mu \mathrm{g} / \mathrm{L})$, DBP $(1.57 \mu \mathrm{g} / \mathrm{L})$, DEHP $(1.35 \mu \mathrm{g} / \mathrm{L})$, DMP $(1.13 \mu \mathrm{g} / \mathrm{L})$, and DnOP $(0.590 \mu \mathrm{g} / \mathrm{L})$ in the river water samples. DBP and DEHP were the major phthalate derivatives found in the surface water of the Taihu Lake areas. Northern Taihu Lake was surrounded by manufacturing industries, effluent discharge from WWTPs or a few chemical companies discharge into the rivers, and domestic waste discharge, resulting in higher contamination levels compared to southern Taihu Lake [172]. PAE concentrations from Lake Chaohu during summer, autumn, and winter were reported at 1.54 to $13.2 \mu \mathrm{g} / \mathrm{L}, 1.28$ to $5.39 \mu \mathrm{g} / \mathrm{L}$, and 0.370 to $1.48 \mu \mathrm{g} / \mathrm{L}$, respectively. DIBP and DBP in Lake Chaohu were found in elevated concentrations during all seasons, followed by DMP and DEP; whereas BBP and DEHP concentrations were lower $[169,173]$. The PAEs were widespread in water and sediment samples at Taihu Lake, although DBP and DEHP concentration were high in water [174].

Several factors influence PAE concentrations, such as runoff, atmospheric deposition, suspended particulate matter (SPM) deposition, degradation, and variation in dissolved organic matter (DOM) [175,176]. Lee et al. [89] analyzed 14 different PAEs in air, water, sediment, and fish from Asan Lake, Korea. Total PAE concentrations in water from Asan Lake ranged from ND (nondetectable) to $2.29 \mu \mathrm{g} / \mathrm{L}$, and DEHP (range: ND-1.34 $\mu \mathrm{g} / \mathrm{L}$ ) was the predominant compound, followed by DMP (range: ND-0.18 $\mu \mathrm{g} / \mathrm{L}$ ). The authors also reported the highest values of PAEs during summer (mean: $0.449 \pm 0.378 \mu \mathrm{g} / \mathrm{L}$ ) and the lowest in autumn (mean: $0.021 \pm 0.041 \mu \mathrm{g} / \mathrm{L}$ ). DEHP and DBP were frequently found in water samples in all seasons, possibly due to the large usage of DEHP around Asan Lake in Korea. In addition, an another study reported three phthalates (DMP, BBP, and DnOP) in four major rivers in Korea [177] (Table 3). In general, PAE concentrations were comparatively lower in upstream (Jinwi and Anseong streams) than in downstream (Asan Lake) sites. 
Zheng et al. studied distribution and seasonal variation of phthalate acid esters in lakes of Beijing, China [178]. The authors found that low hydrophobic PAEs (DMP (median: $0.044 \mu \mathrm{g} / \mathrm{L}$ ) and DEP (median: $0.122 \mu \mathrm{g} / \mathrm{L}$ )) were higher during the summer, and a lower DMP concentration was found in autumn than during winter. Lower concentrations of DIBP, DBP, and BBP were reported in winter. Water flow plays a major role in the concentration variation in different seasons, and water flow was relatively low during the summer compared to winter and autumn. Elevated concentrations during summer may be due to a lower volume of water to dilute the contaminant input.

\subsection{Phthalates in Soil/Sediment}

Table 3 presents contamination levels of phthalates and their derivatives, including DMP, DEP, DBP, BBP, DEHP, and di-n-octyl phthalate (DnOP), in water and sediment from several countries. PAE concentrations in sediment from the Jiulong River (Southeast China) ranged from 0.001 to $56.17 \mathrm{mg} / \mathrm{kg}$, and the frequently detected PAEs were DMP, DEP, DBP, and DEHP [169]. The highest PAE concentrations were found in Taihu Lake at $20.9 \mathrm{mg} / \mathrm{kg}$, followed by $17.8 \mathrm{mg} / \mathrm{kg}$ and $17.4 \mathrm{mg} / \mathrm{kg}$, respectively. He et al. [179] studied seasonal variations in the PAEs in particulate phase in Lake Chaohu. The authors found $103 \mu \mathrm{g} / \mathrm{g}, 101 \mu \mathrm{g} / \mathrm{g}$, and $356 \mu \mathrm{g} / \mathrm{g}$ during summer, autumn, and winter, respectively. PAE concentrations were the highest in winter due to lower precipitation and lower water levels. Bianucci et al. reported the enhanced sediment resuspension during monsoon season [180]. The PAE concentrations in sediment from Asan Lake in Korea ranged from 3.6 to $8973 \mu \mathrm{g} / \mathrm{kg} \mathrm{dw}$. DEHP (range: 3.6-8326 $\mu \mathrm{g} / \mathrm{kg} \mathrm{dw}$ ) was the principal compound, followed by DBP (range: ND-535 $\mu \mathrm{g} / \mathrm{kg} \mathrm{dw}$ ) [89]. The PAE concentrations were highest in summer (mean: $2356 \pm 2450 \mu \mathrm{g} / \mathrm{kg} \mathrm{dw}$ ) and lowest in spring (mean: $1847 \pm 2359 \mu \mathrm{g} / \mathrm{kg} \mathrm{dw}$ ); DBP and DEHP were reported in all seasons. High amounts of DBP were detected in winter compared to other seasons, whereas DEHP was the predominant compound in the total PAE concentration. This demonstrates the wide usage of DEHP in Korea. Specifically, DEHP concentration was constant in all four seasons, which implies that DEHP concentration in sediment was independent in all seasons. Furthermore, DEHP tended to partition to sediments due to its high octanol-water partition coefficient $(\log K o w=7.73)$.

Severe PAE contamination in soil, water, and air of China has been compared to other countries [82] (Table 3). Higher PAE concentrations ( $\left.\sum_{16 \mathrm{PAEs}}\right)$ in soil from Beijing, Guangzhou ranged from 0.001 to $1232 \mathrm{mg} / \mathrm{kg}$ compared to soils from France and Serbia [181,182]. Many reports illustrated the contamination of soil from cotton fields (South Xinjiang) ( $\sum_{6 \mathrm{PAEs}}: 124-1232 \mathrm{mg} / \mathrm{kg}$ ), and nonindustrialized (range: $2.1-158 \mathrm{mg} / \mathrm{kg}$ ) and electronic industrialized areas (range: $8.6-172 \mathrm{mg} / \mathrm{kg}$ ) in Xiangyang. Higher PAE concentrations were observed in the highly industrialized areas compared to nonindustrialized areas $[183,184]$. Lu et al. [185] demonstrated the predominance of DBP (ND-31.2 mg/kg) and DEHP in most of the soil samples. They also quantified the highest DEHP concentration $(6.60 \mathrm{mg} / \mathrm{kg})$ in the soil of Guangdong Province, followed by Shandong and Hubei Provinces $(4.9 \mathrm{mg} / \mathrm{kg})$. DBP was observed at an average concentration $(>2.0 \mathrm{mg} / \mathrm{kg})$ in Shandong, Heilongjiang, and Guangdong Provinces, and average concentrations of DBP and DEHP $(<1.0$ and $3.0 \mathrm{mg} / \mathrm{kg})$ were observed in other provinces. These findings exhibited the regional variation of PAE concentrations in soils of China, because of differences in urbanization, industrialization, use of huge plastic films in agriculture fields, use of municipal biosolids, wastewater irrigation, etc. Guo and $\mathrm{Wu}$ [183] reported the average concentrations of DBP and DEHP were $<10 \mathrm{mg} / \mathrm{kg}$ (except soil in South Xinjiang and Qingdao) and $<25 \mathrm{mg} / \mathrm{kg}$ (range: ND-264 mg/kg) (except soil in South Xinjiang), respectively [186,187]. Most of the studies reported lower concentrations of DBP than DEHP in soils at the same site, which was opposite in some cases [109,188].

\subsection{Phthalates in Fish}

Phthalate concentrations in different fish species are presented in Table 3. Lee et al. selected four different fish species (Crucian carp, skygager, bluegill, and bass) to study 
the PAE contamination in Asan Lake in Korea [89]. The total PAE concentrations in fish ranged from ND to $1081 \mu \mathrm{g} / \mathrm{kg} \mathrm{dw}$. Among the various phthalate derivatives, DEHP (range: ND-568 $\mu \mathrm{g} / \mathrm{kg} \mathrm{dw}$ ) was the predominant compound detected in the fish samples, followed by dicyclohexyl phthalate (DCHP). Considering the concentration and detection frequency, DMP had a range of ND to $107 \mu \mathrm{g} / \mathrm{kg} \mathrm{dw}$, with a detection frequency of $56.7 \%$, whereas the DBP concentration range was ND-10.9 $\mu \mathrm{g} / \mathrm{kg} \mathrm{dw}$, and its detection frequency was $63.3 \%$ in all the fish samples. Crucian carp muscle $(222 \pm 228 \mu \mathrm{g} / \mathrm{kg} \mathrm{dw})$ was detected with the highest mean concentration of PAEs, followed by skygager $(173 \pm 192 \mu \mathrm{g} / \mathrm{kg} \mathrm{dw})$ and bluegill $(117 \pm 115 \mu \mathrm{g} / \mathrm{kg} \mathrm{dw})$. However, DEHP was predominant in crucian carp and skygager, and DCHP was higher in bluegill and bass. Some of the factors that influence PAE concentrations in fish species include feeding behavior, tropic level, metabolic transformation, and bioavailability of these contaminants [189]. There was a positive correlation between PAEs in fish, water, and sediment. PAE concentrations in crucian carp and skygager had a positive correlation with water and sediment, because these were benthic feeding fish that live in close proximity with sediments. Benthic feeding fish species and benthic invertebrates contained high level of PAEs, especially DEHP [190]. Higher-solubility PAEs had higher bioavailability in water, whereas sediment had lower bioavailability for certain PAEs. High molecular weight PAEs were greatly absorbed by sediments compared to low molecular weight PAEs, hence these factors influenced the bioaccumulation of PAEs in fish [89].

Table 3. Phthalates in environmental matrices and human samples.

\begin{tabular}{|c|c|c|c|c|}
\hline \multicolumn{5}{|c|}{ Concentration of Phthalate Compounds in Water } \\
\hline Sampling Area & Compound & Concentration & Unit & Reference \\
\hline \multirow{6}{*}{ Chaohu Lake, China } & DMP & $0.015-3.670$ & \multirow{6}{*}{$\mu \mathrm{g} / \mathrm{L}$} & \multirow{6}{*}{ [173] } \\
\hline & DEP & $0.006-0.283$ & & \\
\hline & BBP & ND-0.107 & & \\
\hline & DnBP & $0.070-17.529$ & & \\
\hline & DEHP & ND-0.576 & & \\
\hline & $\mathrm{DnOP}$ & ND-0.045 & & \\
\hline \multirow{6}{*}{ Songhua River, China } & DMP & $0.98-4.12$ & \multirow{6}{*}{$\mathrm{ng} / \mathrm{mL}$} & \multirow{6}{*}{ [191] } \\
\hline & DEP & $1.33-6.67$ & & \\
\hline & BBP & ND-4.39 & & \\
\hline & DBP & $1.69-11.8$ & & \\
\hline & DEHP & $2.26-11.6$ & & \\
\hline & DOP & $0.69-6.14$ & & \\
\hline \multirow{4}{*}{ Jiulong River, China } & DMP & $0.03-0.24$ & \multirow{4}{*}{$\mu \mathrm{g} / \mathrm{L}$} & \multirow{4}{*}{ [169] } \\
\hline & DEP & $0.03-0.22$ & & \\
\hline & DBP & $0.3-2.4$ & & \\
\hline & DEHP & $0.9-3.6$ & & \\
\hline \multirow{4}{*}{ Rhone River, France } & DMP & $0.003-0.005$ & \multirow{4}{*}{$\mu \mathrm{g} / \mathrm{L}$} & \multirow{4}{*}{ [192] } \\
\hline & DEP & $0.016-0.031$ & & \\
\hline & DBP & $0.022-0.041$ & & \\
\hline & DEHP & $0.039-0.407$ & & \\
\hline \multirow{2}{*}{ Al-Khobar, Saudi Arabia } & DEP & 6.98 & \multirow{2}{*}{$\mu g / L$} & \multirow{2}{*}{ [193] } \\
\hline & DBP & 7.9 & & \\
\hline \multirow{6}{*}{ Taihu Lake } & DMP & ND-1.32 & \multirow{6}{*}{$\mu \mathrm{g} / \mathrm{L}$} & \multirow{6}{*}{ [171] } \\
\hline & DEP & $0.08-4.79$ & & \\
\hline & $\mathrm{BBP}$ & $0.08-4.72$ & & \\
\hline & DBP & ND-2.54 & & \\
\hline & DEHP & ND-1.41 & & \\
\hline & DnOP & $0.07-0.590$ & & \\
\hline
\end{tabular}


Table 3. Cont.

\begin{tabular}{|c|c|c|c|c|c|}
\hline \multicolumn{6}{|c|}{ Concentration of Phthalate Compounds in Water } \\
\hline Sampling Area & & Compound & Concentration & Unit & Reference \\
\hline \multirow{18}{*}{$\begin{array}{c}\text { Chaohu Lake, } \\
\text { China }\end{array}$} & \multirow{6}{*}{ Summer } & DMP & $0.021-0.193$ & \multirow{18}{*}{$\mu \mathrm{g} / \mathrm{L}$} & \multirow{18}{*}{ [179] } \\
\hline & & DEP & $0.078-0.174$ & & \\
\hline & & BBP & $0.001-0.003$ & & \\
\hline & & DBP & $0.463-11.2$ & & \\
\hline & & DEHP & ND-0.067 & & \\
\hline & & DiBP & $0.918-11.1$ & & \\
\hline & \multirow{6}{*}{ Autumn } & DMP & ND-0.111 & & \\
\hline & & DEP & $0.024-0.160$ & & \\
\hline & & BBP & $0.001-0.011$ & & \\
\hline & & DBP & $0.426-3.65$ & & \\
\hline & & DEHP & ND-0.086 & & \\
\hline & & DiBP & $0.832-2.64$ & & \\
\hline & \multirow{6}{*}{ Winter } & DMP & $0.006-0.099$ & & \\
\hline & & DEP & $0.010-0.102$ & & \\
\hline & & BBP & $0.001-0.004$ & & \\
\hline & & DBP & $0.098-0.465$ & & \\
\hline & & DEHP & $0.002-0.217$ & & \\
\hline & & DiBP & $0.210-1.08$ & & \\
\hline \multirow{6}{*}{ Asan Lake, Korea } & & DMP & ND-0.18 & \multirow{6}{*}{$\mu \mathrm{g} / \mathrm{L}$} & \multirow{6}{*}{ [89] } \\
\hline & & DEP & ND-0.05 & & \\
\hline & & DBP & ND-0.34 & & \\
\hline & & DEHP & ND-1.34 & & \\
\hline & & $\mathrm{DnOP}$ & ND-0.02 & & \\
\hline & & DiBP & ND-0.07 & & \\
\hline \multirow{2}{*}{ Gernika } & & BBP & $19 \pm 1$ & \multirow{8}{*}{$\mathrm{ng} / \mathrm{L}$} & \multirow{8}{*}[161]{} \\
\hline & & DEHP & $641 \pm 195$ & & \\
\hline \multirow{2}{*}{ Ondarroa } & & BBP & $16 \pm 3$ & & \\
\hline & & DEHP & $350 \pm 26$ & & \\
\hline \multirow{2}{*}{ Deba } & & BBP & $20 \pm 1$ & & \\
\hline & & DEHP & $1595 \pm 416$ & & \\
\hline \multirow{2}{*}{ Pasaia } & & BBP & $20 \pm 3$ & & \\
\hline & & DEHP & $806 \pm 380$ & & \\
\hline \multicolumn{6}{|c|}{ Concentration of Phthalates in Sediment } \\
\hline Sampling Area & & Compound & Concentration & Unit & Reference \\
\hline \multirow{6}{*}{\multicolumn{2}{|c|}{ Pearl River, China }} & DMP & $0.001-0.019$ & \multirow{6}{*}{$\mathrm{mg} / \mathrm{kg}$} & \multirow{6}{*}{ [194] } \\
\hline & & DEP & $0.001-0.091$ & & \\
\hline & & BBP & ND-0.113 & & \\
\hline & & DBP & $0.042-5.03$ & & \\
\hline & & DEHP & $0.415-29.5$ & & \\
\hline & & $\mathrm{DnOP}$ & ND-0.181 & & \\
\hline & & DMP & ND-0.179 & & \\
\hline & & DEP & ND-0.218 & & \\
\hline Oizntano Pinor Ching & & $\mathrm{BBP}$ & ND-0.021 & $\mathrm{mo} / \mathrm{kg}$ & 17701 \\
\hline Qlaming Nuver, Crima & & DnBP & $0.034-0.241$ & 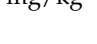 & {$[170]$} \\
\hline & & DEHP & $0.365-6.24$ & & \\
\hline & & $\mathrm{DnOP}$ & ND-0.019 & & \\
\hline & & DMP & ND-0.004 & & \\
\hline Jiulong River Chin & & DEP & ND-0.002 & & \\
\hline & & DBP & $0.004-0.23$ & ing/ kg & [109] \\
\hline & & DEHP & $0.053-1.28$ & & \\
\hline
\end{tabular}


Table 3. Cont.

\begin{tabular}{|c|c|c|c|c|c|}
\hline \multicolumn{6}{|c|}{ Concentration of Phthalates in Sediment } \\
\hline Sampling Area & & Compound & Concentration & Unit & Reference \\
\hline \multirow{6}{*}{ Songhua River, China } & & DMP & $0.03-0.09$ & \multirow{6}{*}{$\mathrm{mg} / \mathrm{kg}$} & \multirow{6}{*}{ [191] } \\
\hline & & DEP & $0.03-0.04$ & & \\
\hline & & BBP & ND-0.10 & & \\
\hline & & DBP & $0.06-0.88$ & & \\
\hline & & DEHP & $0.23-0.57$ & & \\
\hline & & DnOP & ND-0.38 & & \\
\hline \multirow{4}{*}{\multicolumn{2}{|c|}{ Ogun River, Nigeria }} & DMP & ND-0.85 & \multirow{4}{*}{$\mathrm{mg} / \mathrm{kg}$} & \multirow{4}{*}{ [189] } \\
\hline & & DEP & $0.08-0.35$ & & \\
\hline & & DBP & $0.19-1.42$ & & \\
\hline & & DEHP & $0.02-0.82$ & & \\
\hline \multirow{5}{*}{ Gomti River, India } & & DMP & ND-0.05 & \multirow{5}{*}{$\mathrm{mg} / \mathrm{kg}$} & \multirow{5}{*}{ [195] } \\
\hline & & DEP & ND-0.035 & & \\
\hline & & DBP & ND-0.034 & & \\
\hline & & DEHP & ND-0.324 & & \\
\hline & & DnOP & ND-0.053 & & \\
\hline \multirow{6}{*}{ Taihu Lake } & & DMP & $0.950-3.50$ & \multirow{6}{*}{$\mathrm{mg} / \mathrm{kg}$} & \multirow{6}{*}[171]{} \\
\hline & & DEP & $0.590-2.290$ & & \\
\hline & & $\mathrm{BBP}$ & $0.420-1.30$ & & \\
\hline & & DBP & $0.5-1.75$ & & \\
\hline & & DEHP & $0.550-4.77$ & & \\
\hline & & DnOP & $0.480-16.2$ & & \\
\hline \multirow{18}{*}{ Lake Chaohu, China } & \multirow{6}{*}{ Summer } & DMP & $0.627-13.4$ & \multirow{18}{*}{$\mu \mathrm{g} / \mathrm{g}$} & \multirow{18}{*}{ [179] } \\
\hline & & DEP & $0.599-12.08$ & & \\
\hline & & BBP & ND-0.688 & & \\
\hline & & DBP & $3.26-108$ & & \\
\hline & & DEHP & $1.99-48.6$ & & \\
\hline & & DiBP & $7.94-225$ & & \\
\hline & \multirow{6}{*}{ Autumn } & DMP & $0.430-226$ & & \\
\hline & & DEP & $0.475-149$ & & \\
\hline & & BBP & ND-4.69 & & \\
\hline & & DBP & $4.86-1307$ & & \\
\hline & & DEHP & $1.69-1059$ & & \\
\hline & & DiBP & $9.58-4383$ & & \\
\hline & \multirow{6}{*}{ Winter } & DMP & $12.8-434$ & & \\
\hline & & DEP & $3.22-55.9$ & & \\
\hline & & BBP & ND-28.4 & & \\
\hline & & DBP & $10.6-285$ & & \\
\hline & & DEHP & $6.08-372$ & & \\
\hline & & DiBP & $25.5-548$ & & \\
\hline \multirow{5}{*}{ Asan lake, Korea } & & DMP & ND-6.4 & \multirow{5}{*}{$\mu \mathrm{g} / \mathrm{kg} \mathrm{dw}$} & \multirow{5}{*}{ [89] } \\
\hline & & DEP & ND-4.1 & & \\
\hline & & DBP & ND-535 & & \\
\hline & & DEHP & $3.6-8326$ & & \\
\hline & & DiBP & ND-43 & & \\
\hline
\end{tabular}


Table 3. Cont.

\begin{tabular}{|c|c|c|c|c|}
\hline \multicolumn{5}{|c|}{ Concentration of Phthalates in Fish } \\
\hline Sampling Area & Compound & Concentration & Unit & Reference \\
\hline \multirow{7}{*}{$\begin{array}{c}\text { Asan Lake, Korea } \\
\text { (crucian carp, skygager, bass, bluegill) }\end{array}$} & DMP & ND-10.9 & \multirow{7}{*}{$\mu \mathrm{g} / \mathrm{kg} \mathrm{dw}$} & \multirow{7}{*}{ [89] } \\
\hline & DEP & ND-13.6 & & \\
\hline & DBP & ND-107 & & \\
\hline & DEHP & ND-568 & & \\
\hline & $\mathrm{DnOP}$ & ND-34.2 & & \\
\hline & DiBP & ND-29.4 & & \\
\hline & $\mathrm{BBP}$ & ND-65.0 & & \\
\hline
\end{tabular}

\section{Human Exposure}

\subsection{Parabens}

Contamination of aquatic systems with EDCs contributes to bioaccumulation and biomagnification in shellfish, fish, and other organisms, which may ultimately enter humans through the food chain. In vitro and in vivo studies showed parabens and their metabolites may lead to estrogenic activity in males, which leads to male infertility and other diseases $[31,196]$. Paraben exposure in humans leads to various adverse health effects, hence many researchers analyzed a variety of environmental and biological samples, including human tissues, to find the sources and pathways of exposure to humans (Table 1 and Figure 4). Dietary exposure to parabens in the Philippines through fish consumption resulted in human exposure of $2 \mu \mathrm{g} / \mathrm{kg} /$ day [35], which was lower than the acceptable daily intake (10 mg/kg/day). Continuous usage of MePB-containing topical formulations resulted in accumulation and increased PB concentration in the stratum corneum of the skin [197]. A study by Janjua et al. [198] reported the effect of PBs by using whole-body topical application of cream containing $2 \%(w / w)$ of BuPB. They reported fast penetration into the skin and systemic uptake of BuPB, resulting in $135 \mu \mathrm{g} / \mathrm{L}$ of BuPB in serum $3 \mathrm{~h}$ after application. This concentration decreased to $18 \mu \mathrm{g} / \mathrm{L} 24 \mathrm{~h}$ after exposure. Exposure to $\mathrm{BuPB}$ through topical application did not alter any reproductive hormone levels. Exposure to PBs did not have any positive relative relationship between PB concentrations in urine, hormone levels, and semen quality. However, BuPB concentration damaged sperm DNA [199] (Figure 4). Koeppe et al. [200] found elevated PB concentrations in urinary samples of women compared to men. According to Ye et al. serum samples contained several parabens, including MePB, EtPB, and PrPB, with median concentrations of $10.9 \mu \mathrm{g} / \mathrm{L}$, $0.2 \mu \mathrm{g} / \mathrm{L}$, and $1.4 \mu \mathrm{g} / \mathrm{L}$, respectively [201]. Different PB concentrations in serum samples may be due to variations in exposure to PB between sexes.

Measurable concentrations of PBs were also found in other matrices. Human breast milk, placenta, serum, and urine samples from the United States, Korea, Belgium, Spain and Taiwan contained measurable concentrations of PBs (Table 1). MePB, EtPB, and PrPB are the most common PBs found in the samples. The concentration of parabens in human milk and urine samples confirms the widespread usage of parabens. Presence of parabens in placental tissues is of great concern since these compounds could accumulate in amniotic fluid and cause adverse effects to fetus/newborn infants [30,202]. The endocrine disrupting potential of parabens raises concern among researchers. The toxicity of parabens (acute and chronic) on human have been found to be in the following order: $\mathrm{MePB}<\mathrm{EtPB}<\operatorname{PrPB}<\mathrm{BuPB}<\mathrm{BePB}$ [105]. 


\section{Parabens}

- Breast cancer, infertility, sperm DNA damage, hormone imbalance (reduce testosterone level, increase estrogen level) and reduce sperm quality.

\section{Phenolics}

- Damage prostate and breast, cardiovascular disease, alter immune system activity, diabetes in adults, puberty, hormone dependent tumour, endometrial hyperplasia, recurrent miscarriages, PCOS, alterations in puberty timing, blood pressure, reduced oocyte maturation, preterm delivery, preeclampsia, shortened gestation length, oocyte retrieval number, and shorter anogenital distance in male offspring.

- Endometriosis, subfertility, pregnancy problems, malformation of male organs, manifest at cryptorchidism, gynecomastia, abnormal sperm, allergies, neuro-developmental problems in children's, testicular dysgenesis syndrome, impaired spermatogenesis, affects folliculogenesis and steriodogenesis, and decrease fertilization.

Figure 4. Human health effects of EDCs.

Dualde et al. [114] reported parabens concentrations in breast milk samples from the Valencian region, Spain. MePB and PrPB ranges were $0.11-7 \mathrm{ng} / \mathrm{mL}$ and $0.13-0.76 \mathrm{ng} / \mathrm{mL}$, respectively, which were lower (MePB: 0.5-21 ng/mL; PrPB: 0.1-12 ng/mL), than in another study from North Carolina, USA [115]. Similarly, EtPB concentrations in breast milk from mothers from the Valencian region of Spain ranged between 0.49 and $4.05 \mathrm{ng} / \mathrm{mL}$, which was higher than in other studies $(0.6-22 \mathrm{ng} / \mathrm{mL})$ [117]. Only a few studies reported BuPB in human breast milk samples (Table 1) [114,118].

Biomonitoring of EDCs in the placenta provides an exceptional opportunity to understand the exchanges of exogenous compounds between mother and fetus. Not many studies are available on the effects of EDCs on the human placenta [202]. The exposure to EDCs even before birth through transfer between mother and fetus was documented in marine mammals [203]. Van Overmeier et al. [119] quantified the paraben levels in placenta samples from Belgium (MePB: 0.5-7.1 ng/g; EtPB: 0.5-4.5 ng/g; PrPB: 0.5-9.1 ng/g). Placenta samples from Spain exhibited a wide range of concentrations of MePB (50 placenta samples: $0.2-10 \mathrm{ng} / \mathrm{g} ; 10$ placenta samples: $0.8-16.1 \mathrm{ng} / \mathrm{g} ; 12$ placenta samples: 1.2-11.8 ng/g; 10 placenta samples: $1.0-16.8 \mathrm{ng} / \mathrm{g}$ ) [116,204]. A few other reports showed maximum concentrations of EtPB, PrPB, and BuPB in placenta samples of 1.0, 0.8, and $1.6 \mathrm{ng} / \mathrm{g}$, respectively $[205,206]$. MePB and PrPB were the predominant compounds among other parabens in urine samples from Belgium [207]. Some of the characteristics that determine the accumulation of parabens in tissues include concentrations and duration of exposure to EDCs, different biological behavior, and metabolism of EDCs [208]. Ubiquitous distribution of MePB in humans can be easily explained by the common use of cosmetics and hygiene products. BePB raises great concerns due to its broad application. BePB was associated with breast cancer and obesity. Among PBs, BePB is a highly lipophilic and has low water solubility, and therefore is relatively more persistent, leading to a higher detection frequency $[209,210]$. Dermal exposure to parabens via socks resulted in elevated occurrence of parabens in children. Varying concentrations of PBs were found with different durations of exposure: $0.60 \mathrm{pg} / \mathrm{kg} /$ day (24-36 months) followed by $0.39 \mathrm{pg} / \mathrm{kg} / \mathrm{day}$ (6-12 months), and $0.33 \mathrm{pg} / \mathrm{kg} /$ day (1-6 months) [211]. 


\subsection{Phenols}

The main route of human exposure to BPA was via the ingestion of packaged food and water. Phenols are quickly absorbed by the gastrointestinal tract and metabolized in the liver and intestine. BPA exposure via polycarbonate water bottles increased as these water bottles were stored at elevated temperatures (BPA migrated to water at a rate 55-fold higher at $\left.100{ }^{\circ} \mathrm{C}\right)$ [212-214]. Some of the factors that influence the effect of EDCs on humans are:

1. Age;

2. Concentration (exposure magnitude);

3. Duration of exposure both internal and external; and

4. Involvement of a mixture of pollutants (one or more compounds) $[215,216]$.

Infants were highly exposed to BPA through mother's milk and use of polycarbonate feeding bottles [217]. Many reports showed the presence of bisphenols (range: 0.01 to $30 \mathrm{ng} / \mathrm{mL}$ ) and parabens (range: 0.1 to $1000 \mathrm{ng} / \mathrm{mL}$ ) in breast milk [218,219]. Bisphenols and parabens can conjugate with glucuronides and sulfate groups, and both the conjugated and unconjugated forms were found in breast milk, reducing the potential of toxicity and excreted via urine [220]. Very few studies reported unconjugated BPA (0.2 to $1 \mathrm{ng} / \mathrm{mL}$ ) [221]. BPF and BPS were detected in human breast milk at concentrations of 0.13 to $0.32 \mathrm{ng} / \mathrm{mL}$ [114]. A few studies reported bisphenol levels in placenta, urine, and plasma samples (Table 2). Van Overmeier et al. [119] reported BPA (0.5-3.9 ng/g), BPF (0.6-2.1 ng/g), BPS (0.8-1.3 ng/g), and OP (0.5-3.7 ng/g) in placenta samples. BPA was found at the highest level in placenta samples, followed by BPS and BPF. Studies from countries including Spain (49 samples: 1.1-22.2 ng/g; 10 samples: 4.2-14.5 ng/g), Canada (21 samples: 1.0-7.8 ng/g) and Korea (257 samples: <LOD-53 ng/g)) [153,222] reported lower concentrations of BPA in placenta samples. BPS and BPF were found in plasma and urine samples, but no reports are available on BPS and BPF in placenta samples [223].

BPA in maternal plasma $(0.059 \mathrm{ng} / \mathrm{mL})$ and cord plasma $(0.132 \mathrm{ng} / \mathrm{mL})$ were determined in women at 37 weeks pregnancy (aged $33 \pm 4.1$ years). Total bisphenol analogues in maternal and cord plasma were 0.61 and $0.105 \mathrm{ng} / \mathrm{mL}$, respectively. Excessive BPA levels were observed in the cord blood compared to maternal plasma [224]. BPA accumulation in the fetal compartment resulted in a higher level in cord plasma, which was reported in other studies. BPA in blood circulation can be transported across the human placenta and into the cord blood of the fetus [225]. Takahashi and Oishi [226] reported that a small amount of BPA was converted into its conjugated form by animal placental UDP-glucuronyl transferase and sulfo transferase; hence, the remaining BPA was active in the fetal compartment. In 2008 , a study conducted in Korea revealed $84 \%$ of maternal serum was detected with conjugated and unconjugated BPA median concentrations of $2.73 \mu \mathrm{g} / \mathrm{L}$ and $40 \%$ in cord blood serum samples, with a median concentration of $<0.625 \mu \mathrm{g} / \mathrm{L}$, respectively [213]. In the same region, Wan et al. [227] reported unconjugated BPA in maternal serum (mean concentration: $0.7 \mathrm{ng} / \mathrm{mL})$ and fetal serum $(0.6 \mathrm{ng} / \mathrm{mL})$. Kosarac et al. [228] evaluated unconjugated BPA at midpregnancy (median concentration: $0.548 \mathrm{ng} / \mathrm{mL}$ ), at delivery (median concentration: $1.46 \mathrm{ng} / \mathrm{mL}$ ), and in cord blood serum (median concentration: $1.82 \mathrm{ng} / \mathrm{mL}$ ). Many reports showed elevated levels of BPA in both maternal and cord serum compared to that of plasma. Nonpregnant women were found to have more BPA in their blood serum than pregnant women, due to a higher accumulation of BPA in the fetal compartment. Peripheral and peritoneal fluids had been detected to have BPA, as well as peritoneal fluid found around the female reproductive system, which had a higher BPA level [229]. Unconjugated BPA was present in maternal serum and cord blood serum in ranges of LOD $-4.46 \mathrm{ng} / \mathrm{mL}$ and LOD $-4.60 \mathrm{ng} / \mathrm{mL}$, respectively. A child at 48 months of age was highly impacted by cord blood BPA. BPS, BPB, and BPAF was monitored in human maternal and cord plasma. Conjugated BPS was detected in 4 out of 27 women's sera $(<0.03-0.07 \mathrm{ng} / \mathrm{mL})$ and in 7 cord blood sera $(<0.03-0.12 \mathrm{ng} / \mathrm{mL})$, revealing the placental transport of BPS [224]. Teeguarden et al. [230] reported BPA concentration ( $>100 \mathrm{ppb})$ in serum, fetus umbilical-cord serum, amniotic fluid, and fetal blood in pregnant women. BPA in adult blood was between 0.2 and $20 \mathrm{ppb}$ [63]. 
Human urine (age: 3-15 months), breast milk, and saliva contained detectable levels of BPA [231]. Pregnant women's serum, follicular and amniotic fluid, fetal serum, cord blood, placental tissue, and human fetal livers also contained measurable concentrations of BPA through transport from mother to child [47]. Lower metabolic clearance of BPA in pregnant women leads to transfer of BPA to amniotic fluid from maternal plasma; it accumulates in the uterine cavity, which eventually exposes the fetus to high levels of BPA. According to the literature, BPA can harm various organs, such as the prostate and breast tissue. Further, BPA exposure may lead to several disorders, including cardiovascular disease, altered immune system activity, diabetes in adults, infertility, precocious puberty, hormone-dependent tumors, and different metabolic disorders such as obesity, endometrial hyperplasia, recurrent miscarriages, polycystic ovary syndrome (PCOS), behavioral problems, alterations in puberty timing, asthma, and high blood pressure [232,233] (Figure 4). Women having polycystic ovary syndrome (PCOS) were found to have higher BPA levels in serum than in women without PCOS due to higher circulating testosterone levels in PCOS women, and BPA clearance was decreased in elevated androgen concentration [234]. BPA has been linked with disorders in female reproductive health and pregnancy, such as reduced oocyte maturation, miscarriages, increased risk of preterm delivery, preeclampsia, shortened gestation length, infant anthropometric measures at birth, decreased estradiol levels and oocyte retrieval numbers, and shorter anogenital distance in male offspring $[50,233,235]$. Recent studies have reported that clothes and textiles were manufactured incorporating BPA and other bisphenol analogues, parabens, benzophenones, benzothiazoles, benzotriazoles, TCC, phthalates, and flame retardants, for softening, stiffening, wrinkling, shrinking, antifading, etc. However, some of the chemicals remain in the final product, which ultimately directly or indirectly exposes children to these compounds [236]. Dermal exposure of BPA via socks containing BPA and parabens was highest due to direct contact with the skin. Children in Spain aged 36-48 months were observed with the highest BPA dermal exposure, with a median concentration of $17.6 \mathrm{pg} / \mathrm{kg} /$ day, followed by those aged 24-36 months (dose of $0.75 \mathrm{pg} / \mathrm{kg} /$ day), 6-12 months (dose of $0.46 \mathrm{pg} / \mathrm{kg} /$ day), and 12-24 months (dose of $0.22 \mathrm{pg} / \mathrm{kg}$ /day) [211]. BPA interfered with steroid hormonal activity through human estrogen (hER) and human androgen (hAR) receptors. BPA is an active hER agonist and hAR antagonist [237]. BPA in socks is a major contributor to estrogenic and antiandrogenic activity. The mean dermal exposure dose of BPA was $19.6 \mathrm{pg} / \mathrm{kg} /$ day, whereas the highest dose was observed in socks for older children in Spain. Xue et al. [85] reported that textile products and clothing for infants were detected with higher BPA $(222 \mathrm{pg} / \mathrm{kg} /$ day $)$, and several-fold higher in clothes for children aged $<1$ month, with a mean concentration of $248 \mathrm{pg} / \mathrm{kg} /$ day. The consequences of exposure to BPA and APs include breast cancer, altered growth and body development, and reduced fertility by disturbing reproductive health $[238,239]$.

\subsection{Phthalates}

Phthalates' actions are mainly related to reproductive disorders. Women exposed to phthalates become more vulnerable to several types of cancers, endometriosis, subfertility, and pregnancy problems [240], whereas phthalate syndrome in males can lead to the deformity of male organs and manifest cryptorchidism, gynecomastia, abnormal sperm, and various hormonal problems associated with the reproductive system. Many researchers reported the health effects of phthalates; for example, reproductive system dysfunction, endocrine disorders, asthma, allergies, and neurodevelopment problems in children, and obesity [241-244]. Tan et al. [245] reported that PAEs can bind to human hemoglobin, which leads to erythrocyte dysfunction. Recent studies have reported the binding of nine phthalates to sex hormone binding globulin (SHBG), and long-chain phthalates had a greater potential to disrupt the endocrine system than short-chain length phthalates [65]. Few studies monitored the presence of phthalates and their metabolites in urine. Phthalates and their metabolites were mainly exposed via dietary intake, especially DEHP and mono- 
2-ethyl-hexyl phthalate (MEHP) [246]. DEHP is hydrolyzed into MEHP by plasma lipase; its toxic effects are similar to DEHP and disrupt gene transcription in several ways, such as:

5. Increased thyroid transcription factor I (TTF1) and paired-box gene 8 (Pax8) influence on the thyroid system growth and development;

6. Increased thyroid stimulating hormone beta-subunit (TSH $\beta)$ and sodium/iodide symporter (NIS) and thyroglobulin (TG) results in thyroid hormone synthesis; and

7. Decreased transthyretin (TTR) via thyroid transport [247].

Phthalate exposure starts during fetal development and carries on after birth. PAEs mainly affect the Leydig cells involved in the synthesis of testosterone and growth factor 3 and restrain their levels. This could lead to testicular dysgenesis syndrome, cryptorchidism, and impaired spermatogenesis [248]. Hannon and Flaws [249] reported that the effect of phthalates are more easily understood for male reproduction than female, whereas phthalates can be more toxic to ovaries, affecting folliculogenesis and steroidogenesis (Figure 4). Male partners were found to have phthalate metabolites (monocarboxyloctyl phthalate (MCOP) and mono-3-carboxylpropyl phthalate (MCPP)) in urine, which was related to decreased odds of implantation and live birth [250]. Female partners were found to have phthalate metabolites in urine, despite negative correlations between urinary metabolites of DEHP and oocyte yield, clinical pregnancy, and live birth [251]. They also found reduced fertilization rates in women, due to the presence of urinary phthalate metabolites such as di-isononyl phthalate. Phthalate metabolites in the urine of women (having a male partner) (median level) were: MEP (333 (290) $\mu \mathrm{g} / \mathrm{L}), \operatorname{MnBP}(116(96.4) \mu \mathrm{g} / \mathrm{L})$, MiBP (51.4(47.9) $\mu \mathrm{g} / \mathrm{L})$, MECPP (24.7 (29.9) $\mu \mathrm{g} / \mathrm{L})$, MEOHP (16 (16.2) $\mu \mathrm{g} / \mathrm{L})$, MEHP (13 (14.3) $\mu \mathrm{g} / \mathrm{L}), \operatorname{MEHHP}(8.52(11.1) \mu \mathrm{g} / \mathrm{L})$, and MBzP (1.17 (1.14) $\mu \mathrm{g} / \mathrm{L})$ [252]. MEP and MEHP levels in the urine of women were correlated with high risks of failed clinical pregnancy and live birth. The authors also reported that phthalates and their metabolites in the urine of male and female partners were higher than those in other national surveys $[253,254]$. The MEOHP and DEHP levels in women were associated with a significant decline in fertilization [255]. A few studies reported MEP levels in women $(52.2 \mu \mathrm{g} / \mathrm{L}$; $151 \mu \mathrm{g} / \mathrm{L})$ [251] and men $(57.8 \mu \mathrm{g} / \mathrm{L})$ [250].

DEHP was the highest nondietary ingestion compound, which was one order of magnitude higher than DMP or DEP. For instance, subjects were highly exposed to DiBP and DnBP via dermal absorption than other phthalates. Children were more exposed to phthalates than adults, whereas younger children's (aged $<1$ year) daily intake of phthalates was higher. This poses a greater potential health risk to infants than adults. Bu et al. [256] showed the exposure level of phthalates for adults ranged from $0.23-1.15 \mu \mathrm{g} / \mathrm{kg} /$ day for DEP, 0.2-1.7 $\mu \mathrm{g} / \mathrm{kg} /$ day for DiBP, 0.34-8.7 $\mu \mathrm{g} / \mathrm{kg} /$ day for DnBP, and 0.16-11 $\mu \mathrm{g} / \mathrm{kg} /$ day for DEHP. They found the highest level of DEHP in adults among others, followed by DnBP, DiBP, and DEP. Fromme (2011) investigated phthalate levels in breast milk from women over a 6-month postpartum period. DEHP was dominant, with a median value of $3.9 \mathrm{ng} / \mathrm{g}$, and the median value of DnBP was $1.2 \mathrm{ng} / \mathrm{g}$ in breast milk. This study demonstrated lactational transfer of DEHP from mother to infant through breast milk [257]. Infants from Germany had found DEHP and DnBP ranged from 9.3 to $35.7 \mathrm{ng} / \mathrm{g}$ and 1.7 to $5.5 \mathrm{ng} / \mathrm{g}$, respectively; and similarly in Italy: DEHP (5-5088 ng/g) and DnBP (8-1297 ng/g). A study conducted in Portuguese children indicated a lower intake level of phthalates among obese children compared to regular diet/weight children [258]. However, Gari et al. [259] found elevated levels of high molecular weight phthalates in rural children compared to those in urban children. In contrast, children from urban areas had higher MBzP, MnBP, and MiBP (low molecular weight phthalates) than in rural areas. Phthalate levels from rural areas in Poland were correlated with home equipment, as PAEs had been primarily used in polyvinyl chloride (PVC), building and construction materials, floorings, and furnishings. Children who underwent longer breastfeeding (>6 months) had higher phthalate levels [259].

Exposure levels of EDCs begin at the fetus stage and are associated with increasing health risks in growing children. Urbanization and lack of pollution management will 
lead to higher risks to humans who reside in urban and rural areas. Urban residents were highly exposed to EDCs, due to the surrounding environment and higher usage of EDC-containing products.

\section{Conclusions}

The widespread uses of parabens, phenols, and phthalates in a variety of applications have resulted in environmental contamination. Due to their unique properties, these compounds enter biological tissues and contribute to health disorders. Studies dealing with source identification, long-term monitoring, exposure pathways, and mechanisms of action are essential in order to understand the magnitude of contamination and associated health issues, and actions are required to reduce the exposure and prevent harmful biological effects by these compounds. During the past decade, several studies have documented environmental EDCs as important contributors to overweight/obese conditions in laboratory animals and in humans [256-258]. An excellent review by Darbre [260] reveals the attention paid by the global scientific community to EDCs and obesity [259]. According to an estimate by the World Health Organization (WHO), 1.5 billion adults worldwide are obese or overweight, and the number of people with type 2 diabetes increased from 153 to 347 million between 1980 and 2008 [260]. Further, a recent study found that long-term, low-level chemical exposure to EDCs costs the United States USD 340 billion in annual healthcare spending and lost wages [261]. Specifically, phthalate exposure and low testosterone leading to increased early mortality (10,700 attributable deaths) had an estimated annual cost of USD 8.8 billion, and multiple exposure to autism and ADHD (attention deficit hyperactivity disorder) in children ( $~ 5900$ cases) had an estimated annual cost of USD 2.7 billion [261]. Considering the contamination levels reported in the literature and the environmental and human costs of chemical exposure, it is important to take necessary steps to minimize EDC contamination in a timely manner to protect the global environment, living resources, and human health. Future research is warranted to better understand the environmental distribution, behavior, fate, and health effects of EDCs at the molecular level.

Author Contributions: S.S.: Conceptualization, and Writing original draft. K.V.: Literature collection, Preparation of tables and figures, B.G.L.: Review of manuscript, and editorial corrections. All authors have read and agreed to the published version of the manuscript.

Funding: This research received no external funding.

Institutional Review Board Statement: This manuscript deals with literature review only.

Informed Consent Statement: Not applicable.

Data Availability Statement: Not applicable.

Acknowledgments: The authors acknowledge the anonymous reviewers for their constructive criticism and valuable suggestions for the earlier version of this manuscript. The authors are thankful to Kevin Miller, Department of Chemistry, Murray State University, for his help in the preparation of this manuscript and for useful suggestions.

Conflicts of Interest: The authors declare no conflict of interest.

\section{References}

1. Combarnous, Y. Endocrine Disruptor Compounds (EDCs) and agriculture: The case of pesticides. Comptes Rendus Biol. 2017, 340, 406-409. [CrossRef]

2. Quan, C.; Liu, Q.; Tian, W.; Kikuchi, J.; Fan, S. Biodegradation of an endocrine-disrupting chemical, di-2-ethylhexyl phthalate, by Bacillus subtilis No. 66. Appl. Microbiol. Biotechnol. 2005, 66, 702-710. [CrossRef]

3. Anwer, F.; Chaurasia, S.; Khan, A.A. Hormonally active agents in the environment: A state-of-the-art review. Rev. Environ. Health 2016, 31, 415-433. [CrossRef]

4. Zoeller, R.T.; Bergman, Å.; Becher, G.; Bjerregaard, P.; Bornman, R.; Brandt, I.; Iguchi, T.; Jobling, S.; Kidd, K.A.; Kortenkamp, A. A path forward in the debate over health impacts of endocrine disrupting chemicals. Environ. Health A Glob. Access Sci. Source 2014, 13, 118. [CrossRef] 
5. Diamanti-Kandarakis, E.; Bourguignon, J.-P.; Giudice, L.C.; Hauser, R.; Prins, G.S.; Soto, A.M.; Zoeller, R.T.; Gore, A.C. Endocrinedisrupting chemicals: An Endocrine Society scientific statement. Endocr. Rev. 2009, 30, 293-342. [CrossRef]

6. Golub, M.S.; Doherty, J.D. Triphenyltin as a potential human endocrine disruptor. J. Toxicol. Environ. Healthpart B 2004, 7, 281-295. [CrossRef]

7. Mazur, C.S.; Marchitti, S.A.; Zastre, J. P-glycoprotein inhibition by the agricultural pesticide propiconazole and its hydroxylated metabolites: Implications for pesticide-drug interactions. Toxicol. Lett. 2015, 232, 37-45. [CrossRef]

8. Wadzinski, T.; Altowaireb, Y.; Gupta, R.; Conroy, R.; Shoukri, K. Luteoma of pregnancy associated with nearly complete virilization of genetically female twins. Endocr. Pract. 2014, 20, e18-e23. [CrossRef]

9. Lee, H.R.; Jeung, E.B.; Cho, M.H.; Kim, T.H.; Leung, P.C.; Choi, K.C. Molecular mechanism (s) of endocrine-disrupting chemicals and their potent oestrogenicity in diverse cells and tissues that express oestrogen receptors. J. Cell. Mol. Med. 2013, 17, 1-11. [CrossRef]

10. Legler, J.; Zeinstra, L.M.; Schuitemaker, F.; Lanser, P.H.; Bogerd, J.; Brouwer, A.; Vethaak, A.D.; de Voogt, P.; Murk, A.J.; van der Burg, B. Comparison of in vivo and in vitro reporter gene assays for short-term screening of estrogenic activity. Environ. Sci. Technol. 2002, 36, 4410-4415. [CrossRef] [PubMed]

11. Munier, M.; Grouleff, J.; Gourdin, L.; Fauchard, M.; Chantreau, V.; Henrion, D.; Coutant, R.; Schiøtt, B.; Chabbert, M.; Rodien, P. In vitro effects of the endocrine disruptor p, p'-DDT on human follitropin receptor. Environ. Health Perspect. 2016, 124, 991-999. [CrossRef] [PubMed]

12. Gore, A.C.; Chappell, V.A.; Fenton, S.E.; Flaws, J.A.; Nadal, A.; Prins, G.S.; Toppari, J.; Zoeller, R. EDC-2: The Endocrine Society's second scientific statement on endocrine-disrupting chemicals. Endocr. Rev. 2015, 36, E1-E150. [PubMed]

13. Schrader, T.J.; Cooke, G.M. Examination of selected food additives and organochlorine food contaminants for androgenic activity in vitro. Toxicol. Sci. 2000, 53, 278-288. [CrossRef] [PubMed]

14. Walker, C.L. Minireview: Epigenomic plasticity and vulnerability to EDC exposures. Mol. Endocrinol. 2016, 30, 848-855. [CrossRef]

15. Walker, D.M.; Gore, A.C. Epigenetic impacts of endocrine disruptors in the brain. Front. Neuroendocr. 2017, 44, 1-26. [CrossRef]

16. Zama, A.M.; Uzumcu, M. Fetal and neonatal exposure to the endocrine disruptor methoxychlor causes epigenetic alterations in adult ovarian genes. Endocrinology 2009, 150, 4681-4691. [CrossRef]

17. Zhang, Y.; Wu, L.; Zhang, G.; Guan, Y.; Wang, Z. Effect of low-dose malathion on the gonadal development of adult rare minnow Gobiocypris rarus. Ecotoxicol. Environ. Saf. 2016, 125, 135-140. [CrossRef]

18. Zhou, Q.; Miao, M.; Ran, M.; Ding, L.; Bai, L.; Wu, T.; Yuan, W.; Gao, E.; Wang, J.; Li, G. Serum bisphenol-A concentration and sex hormone levels in men. Fertil. Steril. 2013, 100, 478-482. [CrossRef]

19. Brucker-Davis, F. Effects of environmental synthetic chemicals on thyroid function. Thyroid 1998, 8, 827-856. [CrossRef]

20. Bansal, R.; Zoeller, R.T. Polychlorinated biphenyls (Aroclor 1254) do not uniformly produce agonist actions on thyroid hormone responses in the developing rat brain. Endocrinology 2008, 149, 4001-4008. [CrossRef]

21. Komesli, O.; Muz, M.; Ak, M.; Bakırdere, S.; Gokcay, C. Occurrence, fate and removal of endocrine disrupting compounds (EDCs) in Turkish wastewater treatment plants. Chem. Eng. J. 2015, 277, 202-208. [CrossRef]

22. Maqbool, F.; Mostafalou, S.; Bahadar, H.; Abdollahi, M. Review of endocrine disorders associated with environmental toxicants and possible involved mechanisms. Life Sci. 2016, 145, 265-273. [CrossRef]

23. Preau, L.; Fini, J.B.; Morvan-Dubois, G.; Demeneix, B. Thyroid hormone signaling during early neurogenesis and its significance as a vulnerable window for endocrine disruption. Biochim. Et Biophys. Acta Gene Regul. Mech. 2015, 1849, 112-121. [CrossRef]

24. Jonkers, N.; Sousa, A.; Galante-Oliveira, S.; Barroso, C.M.; Kohler, H.-P.E.; Giger, W. Occurrence and sources of selected phenolic endocrine disruptors in Ria de Aveiro, Portugal. Environ. Sci. Pollut. Res. 2010, 17, 834-843. [CrossRef] [PubMed]

25. Danish, E. Survey of parabens. Part Lous Rev. 2013, 1474, 2013.

26. Soni, M.; Carabin, I.; Burdock, G. Safety assessment of esters of p-hydroxybenzoic acid (parabens). Food Chem. Toxicol. 2005, 43, 985-1015. [CrossRef] [PubMed]

27. Wu, C.; McGinity, J.W. Influence of methylparaben as a solid-state plasticizer on the physicochemical properties of Eudragit ${ }^{\circledR}$ RS PO hot-melt extrudates. Eur. J. Pharm. Biopharm. 2003, 56, 95-100. [CrossRef]

28. Núñez, L.; Tadeo, J.; García-Valcárcel, A.; Turiel, E. Determination of parabens in environmental solid samples by ultrasonicassisted extraction and liquid chromatography with triple quadrupole mass spectrometry. J. Chromatogr. A 2008, 1214, 178-182. [CrossRef]

29. Jewell, C.; Prusakiewicz, J.J.; Ackermann, C.; Payne, N.A.; Fate, G.; Voorman, R.; Williams, F.M. Hydrolysis of a series of parabens by skin microsomes and cytosol from human and minipigs and in whole skin in short-term culture. Toxicol. Appl. Pharmacol. 2007, 225, 221-228. [CrossRef]

30. Kang, S.; Kim, S.; Park, J.; Kim, H.-J.; Lee, J.; Choi, G.; Choi, S.; Kim, S.; Kim, S.Y.; Moon, H.-B. Urinary paraben concentrations among pregnant women and their matching newborn infants of Korea, and the association with oxidative stress biomarkers. Sci. Total Environ. 2013, 461, 214-221. [CrossRef]

31. Liao, C.; Chen, L.; Kannan, K. Occurrence of parabens in foodstuffs from China and its implications for human dietary exposure. Environ. Int. 2013, 57, 68-74. [CrossRef] [PubMed]

32. Jeong, Y.; Xue, J.; Park, K.J.; Kannan, K.; Moon, H.-B. Tissue-specific accumulation and body burden of parabens and their metabolites in small cetaceans. Environ. Sci. Technol. 2018, 53, 475-481. [CrossRef] [PubMed] 
33. Jakimska, A.; Huerta, B.; Bargańska, Ż.; Kot-Wasik, A.; Rodríguez-Mozaz, S.; Barceló, D. Development of a liquid chromatographytandem mass spectrometry procedure for determination of endocrine disrupting compounds in fish from Mediterranean rivers. $J$. Chromatogr. A 2013, 1306, 44-58. [CrossRef] [PubMed]

34. Kim, J.-W.; Ramaswamy, B.R.; Chang, K.-H.; Isobe, T.; Tanabe, S. Multiresidue analytical method for the determination of antimicrobials, preservatives, benzotriazole UV stabilizers, flame retardants and plasticizers in fish using ultra high performance liquid chromatography coupled with tandem mass spectrometry. J. Chromatogr. A 2011, 1218, 3511-3520. [CrossRef]

35. Ramaswamy, B.R.; Kim, J.-W.; Isobe, T.; Chang, K.-H.; Amano, A.; Miller, T.W.; Siringan, F.P.; Tanabe, S. Determination of preservative and antimicrobial compounds in fish from Manila Bay, Philippines using ultra high performance liquid chromatography tandem mass spectrometry, and assessment of human dietary exposure. J. Hazard. Mater. 2011, 192, 1739-1745. [CrossRef]

36. Carmona, E.; Andreu, V.; Picó, Y. Occurrence of acidic pharmaceuticals and personal care products in Turia River Basin: From waste to drinking water. Sci. Total Environ. 2014, 484, 53-63. [CrossRef]

37. Azzouz, A.; Ballesteros, E. Trace analysis of endocrine disrupting compounds in environmental water samples by use of solidphase extraction and gas chromatography with mass spectrometry detection. J. Chromatogr. A 2014, 1360, 248-257. [CrossRef]

38. Renz, L.; Volz, C.; Michanowicz, D.; Ferrar, K.; Christian, C.; Lenzner, D.; El-Hefnawy, T. A study of parabens and bisphenol A in surface water and fish brain tissue from the Greater Pittsburgh Area. Ecotoxicology 2013, 22, 632-641. [CrossRef]

39. Canosa, P.; Rodríguez, I.; Rubi, E.; Negreira, N.; Cela, R. Formation of halogenated by-products of parabens in chlorinated water. Anal. Chim. Acta 2006, 575, 106-113. [CrossRef]

40. Albero, B.; Pérez, R.A.; Sánchez-Brunete, C.; Tadeo, J.L. Occurrence and analysis of parabens in municipal sewage sludge from wastewater treatment plants in Madrid (Spain). J. Hazard. Mater. 2012, 239, 48-55. [CrossRef]

41. Pouillot, A.; Polla, B.; Polla, A. Conservateurs en cosmétologie: Mise au point sur les Parabènes. J. De Médecine Esthétique Et De Chir. Dermatol. 2006, 33, 187-190.

42. Eriksson, E.; Andersen, H.R.; Ledin, A. Substance flow analysis of parabens in Denmark complemented with a survey of presence and frequency in various commodities. J. Hazard. Mater. 2008, 156, 240-259. [CrossRef] [PubMed]

43. Wang, L.; Kannan, K. Characteristic profiles of benzonphenone-3 and its derivatives in urine of children and adults from the United States and China. Environ. Sci. Technol. 2013, 47, 12532-12538. [CrossRef] [PubMed]

44. Xue, J.; Sasaki, N.; Elangovan, M.; Diamond, G.; Kannan, K. Elevated accumulation of parabens and their metabolites in marine mammals from the United States coastal waters. Environ. Sci. Technol. 2015, 49, 12071-12079. [CrossRef] [PubMed]

45. Rochester, J.R.; Bolden, A.L. Bisphenol S and F: A systematic review and comparison of the hormonal activity of bisphenol A substitutes. Environ. Health Perspect. 2015, 123, 643-650. [CrossRef] [PubMed]

46. Chen, D.; Kannan, K.; Tan, H.; Zheng, Z.; Feng, Y.-L.; Wu, Y.; Widelka, M. Bisphenol analogues other than BPA: Environmental occurrence, human exposure, and toxicity a review. Environ. Sci. Technol. 2016, 50, 5438-5453. [CrossRef]

47. Rochester, J.R. Bisphenol A and human health: A review of the literature. Reprod. Toxicol. 2013, 42, 132-155. [CrossRef]

48. Teng, C.; Goodwin, B.; Shockley, K.; Xia, M.; Huang, R.; Norris, J.; Merrick, B.A.; Jetten, A.M.; Austin, C.P.; Tice, R.R. Bisphenol A affects androgen receptor function via multiple mechanisms. Chem. Biol. Interact. 2013, 203, 556-564. [CrossRef]

49. Commission, E. Commission Regulation (EU) No 10/2011 of 14 January 2011 on plastic materials and articles intended to come into contact with food. Off. J. Eur. Union 2011, 12, 1-89.

50. Kolatorova, L.; Duskova, M.; Vitku, J.; Starka, L. Prenatal exposure to bisphenols and parabens and impacts on human physiology. Physiol. Res. 2017, 66, S305-S315. [CrossRef]

51. Jin, H.; Zhu, L. Occurrence and partitioning of bisphenol analogues in water and sediment from Liaohe River Basin and Taihu Lake, China. Water Res. 2016, 103, 343-351. [CrossRef]

52. Liao, C.; Liu, F.; Guo, Y.; Moon, H.-B.; Nakata, H.; Wu, Q.; Kannan, K. Occurrence of eight bisphenol analogues in indoor dust from the United States and several Asian countries: Implications for human exposure. Environ. Sci. Technol. 2012, 46, 9138-9145. [CrossRef] [PubMed]

53. Wang, W.; Abualnaja, K.O.; Asimakopoulos, A.G.; Covaci, A.; Gevao, B.; Johnson-Restrepo, B.; Kumosani, T.A.; Malarvannan, G.; Minh, T.B.; Moon, H.-B. A comparative assessment of human exposure to tetrabromobisphenol A and eight bisphenols including bisphenol A via indoor dust ingestion in twelve countries. Environ. Int. 2015, 83, 183-191. [CrossRef] [PubMed]

54. Yamazaki, E.; Yamashita, N.; Taniyasu, S.; Lam, J.; Lam, P.K.; Moon, H.-B.; Jeong, Y.; Kannan, P.; Achyuthan, H.; Munuswamy, N. Bisphenol A and other bisphenol analogues including BPS and BPF in surface water samples from Japan, China, Korea and India. Ecotoxicol. Environ. Saf. 2015, 122, 565-572. [CrossRef] [PubMed]

55. Vela-Soria, F.; Ballesteros, O.; Zafra-Gómez, A.; Ballesteros, L.; Navalón, A. UHPLC-MS/MS method for the determination of bisphenol A and its chlorinated derivatives, bisphenol S, parabens, and benzophenones in human urine samples. Anal. Bioanal. Chem. 2014, 406, 3773-3785. [CrossRef]

56. Vandenberg, L.N.; Gerona, R.R.; Kannan, K.; Taylor, J.A.; van Breemen, R.B.; Dickenson, C.A.; Liao, C.; Yuan, Y.; Newbold, R.R.; Padmanabhan, V. A round robin approach to the analysis of bisphenol A (BPA) in human blood samples. Environ. Health 2014, 13, 25. [CrossRef]

57. Ye, X.; Wong, L.-Y.; Kramer, J.; Zhou, X.; Jia, T.; Calafat, A.M. Urinary concentrations of bisphenol A and three other bisphenols in convenience samples of US adults during 2000-2014. Environ. Sci. Technol. 2015, 49, 11834-11839. [CrossRef] 
58. Castillo, M.; Riu, J.; Ventura, F.; Boleda, R.; Scheding, R.; Schröder, H.F.; Nistor, C.; Emneus, J.; Eichhorn, P.; Knepper, T.P. Interlaboratory comparison of liquid chromatographic techniques and enzyme-linked immunosorbent assay for the determination of surfactants in wastewaters. J. Chromatogr. A 2000, 889, 195-209. [CrossRef]

59. Magoarou, P. Proceedings of Workshop on Problems Around Sludge, Stresa, Italy, 18-19 November 1999. EUR 19657 EN. 2000. Available online: https://ec.europa.eu/environment/archives/waste/sludge/pdf/workshoppart1.pdf (accessed on 10 May 2021).

60. Martínez-Zapata, M.; Aristizábal, C.; Peñuela, G. Photodegradation of the endocrine-disrupting chemicals 4n-nonylphenol and triclosan by simulated solar UV irradiation in aqueous solutions with Fe (III) and in the absence/presence of humic acids. J. Photochem. Photobiol. A Chem. 2013, 251, 41-49. [CrossRef]

61. Cheng, G.; Sun, M.; Lu, J.; Ge, X.; Zhang, H.; Xu, X.; Lou, L.; Lin, Q. Role of biochar in biodegradation of nonylphenol in sediment: Increasing microbial activity versus decreasing bioavailability. Sci. Rep. 2017, 7, 4726. [CrossRef]

62. Abargues, M.; Giménez, J.; Ferrer, J.; Bouzas, A.; Seco, A. Endocrine disrupter compounds removal in wastewater using microalgae: Degradation kinetics assessment. Chem. Eng. J. 2018, 334, 313-321. [CrossRef]

63. Hess, S.C. Interferentes hormonais no ambiente: Um risco à saúde pública. Eng. Ambient. Espírito St. Do Pinhal 2010, 7, 311-329.

64. Benjamin, S.; Pradeep, S.; Josh, M.S.; Kumar, S.; Masai, E. A monograph on the remediation of hazardous phthalates. J. Hazard. Mater. 2015, 298, 58-72. [CrossRef] [PubMed]

65. Sheikh, I.A.; Tayubi, I.A.; Ahmad, E.; Ganaie, M.A.; Bajouh, O.S.; AlBasri, S.F.; Abdulkarim, I.M.; Beg, M.A. Computational insights into the molecular interactions of environmental xenoestrogens 4-tert-octylphenol, 4-nonylphenol, bisphenol A (BPA), and BPA metabolite, 4-methyl-2, 4-bis (4-hydroxyphenyl) pent-1-ene (MBP) with human sex hormone-binding globulin. Ecotoxicol. Environ. Saf. 2017, 135, 284-291. [CrossRef] [PubMed]

66. Sheikh, I.A.; Turki, R.F.; Abuzenadah, A.M.; Damanhouri, G.A.; Beg, M.A. Endocrine disruption: Computational perspectives on human sex hormone-binding globulin and phthalate plasticizers. PLoS ONE 2016, 11, e0151444. [CrossRef]

67. Net, S.; Sempéré, R.; Delmont, A.; Paluselli, A.; Ouddane, B. Occurrence, fate, behavior and ecotoxicological state of phthalates in different environmental matrices. Environ. Sci. Technol. 2015, 49, 4019-4035. [CrossRef] [PubMed]

68. Polinski, K.J.; Dabelea, D.; Hamman, R.F.; Adgate, J.L.; Calafat, A.M.; Ye, X.; Starling, A.P. Distribution and predictors of urinary concentrations of phthalate metabolites and phenols among pregnant women in the Healthy Start Study. Environ. Res. 2018, 162, 308-317. [CrossRef]

69. Patel, S.; Zhou, C.; Rattan, S.; Flaws, J.A. Effects of endocrine-disrupting chemicals on the ovary. Biol. Reprod. 2015, 93, 20. [CrossRef]

70. Schecter, A.; Lorber, M.; Guo, Y.; Wu, Q.; Yun, S.H.; Kannan, K.; Hommel, M.; Imran, N.; Hynan, L.S.; Cheng, D. Phthalate concentrations and dietary exposure from food purchased in New York State. Environ. Health Perspect. 2013, 121, 473-479. [CrossRef]

71. Katsikantami, I.; Sifakis, S.; Tzatzarakis, M.N.; Vakonaki, E.; Kalantzi, O.-I.; Tsatsakis, A.M.; Rizos, A.K. A global assessment of phthalates burden and related links to health effects. Environ. Int. 2016, 97, 212-236. [CrossRef]

72. Benjamin, S.; Masai, E.; Kamimura, N.; Takahashi, K.; Anderson, R.C.; Faisal, P.A. Phthalates impact human health: Epidemiological evidences and plausible mechanism of action. J. Hazard. Mater. 2017, 340, 360-383. [CrossRef]

73. Berlioz-Barbier, A.; Vauchez, A.; Wiest, L.; Baudot, R.; Vulliet, E.; Cren-Olivé, C. Multi-residue analysis of emerging pollutants in sediment using QuEChERS-based extraction followed by LC-MS/MS analysis. Anal. Bioanal. Chem. 2014, 406, 1259-1266. [CrossRef] [PubMed]

74. Guo, Y.; Wang, L.; Kannan, K. Phthalates and parabens in personal care products from China: Concentrations and human exposure. Arch. Environ. Contam. Toxicol. 2014, 66, 113-119. [CrossRef] [PubMed]

75. Peng, X.; Yu, Y.; Tang, C.; Tan, J.; Huang, Q.; Wang, Z. Occurrence of steroid estrogens, endocrine-disrupting phenols, and acid pharmaceutical residues in urban riverine water of the Pearl River Delta, South China. Sci. Total Environ. 2008, 397, 158-166. [CrossRef] [PubMed]

76. Kasprzyk-Hordern, B.; Dinsdale, R.M.; Guwy, A.J. The occurrence of pharmaceuticals, personal care products, endocrine disruptors and illicit drugs in surface water in South Wales, UK. Water Res. 2008, 42, 3498-3518. [CrossRef] [PubMed]

77. Ramaswamy, B.R.; Shanmugam, G.; Velu, G.; Rengarajan, B.; Larsson, D.J. GC-MS analysis and ecotoxicological risk assessment of triclosan, carbamazepine and parabens in Indian rivers. J. Hazard. Mater. 2011, 186, 1586-1593. [CrossRef] [PubMed]

78. Kimura, K.; Kameda, Y.; Yamamoto, H.; Nakada, N.; Tamura, I.; Miyazaki, M.; Masunaga, S. Occurrence of preservatives and antimicrobials in Japanese rivers. Chemosphere 2014, 107, 393-399. [CrossRef]

79. Jonkers, N.; Kohler, H.-P.E.; Dammshäuser, A.; Giger, W. Mass flows of endocrine disruptors in the Glatt River during varying weather conditions. Environ. Pollut. 2009, 157, 714-723. [CrossRef]

80. González-Mariño, I.; Quintana, J.B.; Rodríguez, I.; Cela, R. Evaluation of the occurrence and biodegradation of parabens and halogenated by-products in wastewater by accurate-mass liquid chromatography-quadrupole-time-of-flight-mass spectrometry (LC-QTOF-MS). Water Res. 2011, 45, 6770-6780. [CrossRef]

81. Peng, X.; Ou, W.; Wang, C.; Wang, Z.; Huang, Q.; Jin, J.; Tan, J. Occurrence and ecological potential of pharmaceuticals and personal care products in groundwater and reservoirs in the vicinity of municipal landfills in China. Sci. Total Environ. 2014, 490, 889-898. [CrossRef] 
82. Sun, J.; Pan, L.; Zhan, Y.; Lu, H.; Tsang, D.C.; Liu, W.; Wang, X.; Li, X.; Zhu, L. Contamination of phthalate esters, organochlorine pesticides and polybrominated diphenyl ethers in agricultural soils from the Yangtze River Delta of China. Sci. Total Environ. 2016, 544, 670-676. [CrossRef] [PubMed]

83. Kung, T.A.; Lee, S.H.; Yang, T.C.; Wang, W.H. Survey of selected personal care products in surface water of coral reefs in Kenting National Park, Taiwan. Sci. Total Environ. 2018, 635, 1302-1307. [CrossRef]

84. Emnet, P.; Gaw, S.; Northcott, G.; Storey, B.; Graham, L. Personal care products and steroid hormones in the Antarctic coastal environment associated with two Antarctic research stations, McMurdo Station and Scott Base. Environ. Res. 2015, 136, 331-342. [CrossRef]

85. Xue, J.; Liu, W.; Kannan, K. Bisphenols, benzophenones, and bisphenol A diglycidyl ethers in textiles and infant clothing. Environ. Sci. Technol. 2017, 51, 5279-5286. [CrossRef]

86. Ma, W.-L.; Zhao, X.; Zhang, Z.-F.; Xu, T.-F.; Zhu, F.-J.; Li, Y.-F. Concentrations and fate of parabens and their metabolites in two typical wastewater treatment plants in northeastern China. Sci. Total Environ. 2018, 644, 754-761. [CrossRef] [PubMed]

87. Delgado, B.; Pino, V.; Anderson, J.L.; Ayala, J.H.; Afonso, A.M.; Gonzalez, V. An in-situ extraction-preconcentration method using ionic liquid-based surfactants for the determination of organic contaminants contained in marine sediments. Talanta 2012, 99, 972-983. [CrossRef] [PubMed]

88. Viglino, L.; Prévost, M.; Sauvé, S. High throughput analysis of solid-bound endocrine disruptors by LDTD-APCI-MS/MS. J. Environ. Monit. 2011, 13, 583-590. [CrossRef] [PubMed]

89. Lee, Y.-M.; Lee, J.-E.; Choe, W.; Kim, T.; Lee, J.-Y.; Kho, Y.; Choi, K.; Zoh, K.-D. Distribution of phthalate esters in air, water, sediments, and fish in the Asan Lake of Korea. Environ. Int. 2019, 126, 635-643. [CrossRef]

90. Feng, J.; Zhao, J.; Xi, N.; Guo, W.; Sun, J. Parabens and their metabolite in surface water and sediment from the Yellow River and the Huai River in Henan Province: Spatial distribution, seasonal variation and risk assessment. Ecotoxicol. Environ. Saf. 2019, 172, 480-487. [CrossRef] [PubMed]

91. Xue, J.; Kannan, K. Accumulation profiles of parabens and their metabolites in fish, black bear, and birds, including bald eagles and albatrosses. Environ. Int. 2016, 94, 546-553. [CrossRef] [PubMed]

92. Peng, X.; Xiong, S.; Ou, W.; Wang, Z.; Tan, J.; Jin, J.; Tang, C.; Liu, J.; Fan, Y. Persistence, temporal and spatial profiles of ultraviolet absorbents and phenolic personal care products in riverine and estuarine sediment of the Pearl River catchment, China. J. Hazard. Mater. 2017, 323, 139-146. [CrossRef] [PubMed]

93. Huang, C.; Wu, L.-H.; Liu, G.-Q.; Shi, L.; Guo, Y. Occurrence and ecological risk assessment of eight endocrine-disrupting chemicals in urban river water and sediments of South China. Arch. Environ. Contam. Toxicol. 2018, 75, 224-235. [CrossRef] [PubMed]

94. Karthikraj, R.; Vasu, A.K.; Balakrishna, K.; Sinha, R.K.; Kannan, K. Occurrence and fate of parabens and their metabolites in five sewage treatment plants in India. Sci. Total Environ. 2017, 593, 592-598. [CrossRef]

95. Moon, H.B.; Choi, H.G.; Lee, P.Y.; Ok, G. Congener-specific characterization and sources of polychlorinated dibenzo-p-dioxins, dibenzofurans and dioxin-like polychlorinated biphenyls in marine sediments from industrialized bays of Korea. Environ. Toxicol. Chem. Int. J. 2008, 27, 323-333. [CrossRef] [PubMed]

96. Moon, H.-B.; Kannan, K.; Choi, M.; Choi, H.-G. Polybrominated diphenyl ethers (PBDEs) in marine sediments from industrialized bays of Korea. Mar. Pollut. Bull. 2007, 54, 1402-1412. [CrossRef] [PubMed]

97. Pérez, R.; Albero, B.; Miguel, E.; Sánchez-Brunete, C. Determination of parabens and endocrine-disrupting alkylphenols in soil by gas chromatography-mass spectrometry following matrix solid-phase dispersion or in-column microwave-assisted extraction: A comparative study. Anal. Bioanal. Chem. 2012, 402, 2347-2357. [CrossRef] [PubMed]

98. Ferreira, A.M.C.; Möder, M.; Laespada, M.F. Stir bar sorptive extraction of parabens, triclosan and methyl triclosan from soil, sediment and sludge with in situ derivatization and determination by gas chromatography-mass spectrometry. J. Chromatogr. A 2011, 1218, 3837-3844. [CrossRef]

99. Villaverde-de-Sáa, E.; Rodil, R.; Quintana, J.B.; Cela, R. Matrix solid-phase dispersion combined to liquid chromatographytandem mass spectrometry for the determination of paraben preservatives in mollusks. J. Chromatogr. A 2016, 1459, 57-66. [CrossRef]

100. Lu, S.; Wang, N.; Ma, S.; Hu, X.; Kang, L.; Yu, Y. Parabens and triclosan in shellfish from Shenzhen coastal waters: Bioindication of pollution and human health risks. Environ. Pollut. 2019, 246, 257-263. [CrossRef]

101. Liao, C.; Lee, S.; Moon, H.-B.; Yamashita, N.; Kannan, K. Parabens in sediment and sewage sludge from the United States, Japan, and Korea: Spatial distribution and temporal trends. Environ. Sci. Technol. 2013, 47, 10895-10902. [CrossRef]

102. Álvarez-Muñoz, D.; Rodríguez-Mozaz, S.; Maulvault, A.L.; Tediosi, A.; Fernández-Tejedor, M.; Van den Heuvel, F.; Kotterman, M.; Marques, A.; Barceló, D. Occurrence of pharmaceuticals and endocrine disrupting compounds in macroalgaes, bivalves, and fish from coastal areas in Europe. Environ. Res. 2015, 143, 56-64. [CrossRef] [PubMed]

103. Esteban, S.; Gorga, M.; Petrovic, M.; González-Alonso, S.; Barceló, D.; Valcárcel, Y. Analysis and occurrence of endocrinedisrupting compounds and estrogenic activity in the surface waters of Central Spain. Sci. Total Environ. 2014, 466, 939-951. [CrossRef]

104. Gorga, M.; Insa, S.; Petrovic, M.; Barceló, D. Occurrence and spatial distribution of EDCs and related compounds in waters and sediments of Iberian rivers. Sci. Total Environ. 2015, 503, 69-86. [CrossRef] [PubMed] 
105. Yamamoto, H.; Tamura, I.; Hirata, Y.; Kato, J.; Kagota, K.; Katsuki, S.; Yamamoto, A.; Kagami, Y.; Tatarazako, N. Aquatic toxicity and ecological risk assessment of seven parabens: Individual and additive approach. Sci. Total Environ. 2011, 410, 102-111. [CrossRef] [PubMed]

106. Terasaki, M.; Takemura, Y.; Makino, M. Paraben-chlorinated derivatives in river waters. Environ. Chem. Lett. 2012, 10, 401-406. [CrossRef]

107. Zhao, X.; Qiu, W.; Zheng, Y.; Xiong, J.; Gao, C.; Hu, S. Occurrence, distribution, bioaccumulation, and ecological risk of bisphenol analogues, parabens and their metabolites in the Pearl River Estuary, South China. Ecotoxicol. Environ. Saf. 2019, 180, 43-52. [CrossRef]

108. Liu, W.-R.; Yang, Y.-Y.; Liu, Y.-S.; Zhao, J.-L.; Zhang, Q.-Q.; Yao, L.; Zhang, M.; Jiang, Y.-X.; Wei, X.-D.; Ying, G.-G. Biocides in the river system of a highly urbanized region: A systematic investigation involving runoff input. Sci. Total Environ. 2018, 624, 1023-1030. [CrossRef]

109. Zhang, Y.; Liang, Q.; Gao, R.; Hou, H.; Tan, W.; He, X.; Zhang, H.; Yu, M.; Ma, L.; Xi, B. Contamination of phthalate esters (PAEs) in typical wastewater-irrigated agricultural soils in Hebei, North China. PLoS ONE 2015, 10, e0137998. [CrossRef]

110. Liu, W.-R.; Zhao, J.-L.; Liu, Y.-S.; Chen, Z.-F.; Yang, Y.-Y.; Zhang, Q.-Q.; Ying, G.-G. Biocides in the Yangtze River of China: Spatiotemporal distribution, mass load and risk assessment. Environ. Pollut. 2015, 200, 53-63. [CrossRef] [PubMed]

111. Calafat, A.M.; Ye, X.; Wong, L.-Y.; Bishop, A.M.; Needham, L.L. Urinary concentrations of four parabens in the US population: NHANES 2005-2006. Environ. Health Perspect. 2010, 118, 679-685. [CrossRef]

112. Casals-Casas, C.; Desvergne, B. Endocrine disruptors: From endocrine to metabolic disruption. Annu. Rev. Physiol. 2011, 73, 135-162. [CrossRef]

113. Frederiksen, H.; Jørgensen, N.; Andersson, A.-M. Parabens in urine, serum and seminal plasma from healthy Danish men determined by liquid chromatography-tandem mass spectrometry (LC-MS/MS). J. Expo. Sci. Environ. Epidemiol. 2011, 21, 262-271. [CrossRef]

114. Dualde, P.; Pardo, O.; Fernández, S.F.; Pastor, A.; Yusà, V. Determination of four parabens and bisphenols A, F and S in human breast milk using QuEChERS and liquid chromatography coupled to mass spectrometry. J. Chromatogr. B 2019, 1114, 154-166. [CrossRef] [PubMed]

115. Hines, E.P.; Mendola, P.; von Ehrenstein, O.S.; Ye, X.; Calafat, A.M.; Fenton, S.E. Concentrations of environmental phenols and parabens in milk, urine and serum of lactating North Carolina women. Reprod. Toxicol. 2015, 54, 120-128. [CrossRef] [PubMed]

116. Vela-Soria, F.; Jiménez-Díaz, I.; Díaz, C.; Pérez, J.; Iribarne-Durán, L.M.; Serrano-López, L.; Arrebola, J.P.; Fernández, M.F.; Olea, N. Determination of endocrine-disrupting chemicals in human milk by dispersive liquid-liquid microextraction. Bioanalysis 2016, 8, 1777-1791. [CrossRef] [PubMed]

117. Vela-Soria, F.; Iribarne-Durán, L.; Mustieles, V.; Jiménez-Díaz, I.; Fernández, M.; Olea, N. QuEChERS and ultra-high performance liquid chromatography-tandem mass spectrometry method for the determination of parabens and ultraviolet filters in human milk samples. J. Chromatogr. A 2018, 1546, 1-9. [CrossRef]

118. Azzouz, A.; Rascón, A.J.; Ballesteros, E. Determination of free and conjugated forms of endocrine-disrupting chemicals in human biological fluids by GC- MS. Bioanalysis 2016, 8, 1145-1158. [CrossRef]

119. Van Overmeire, I.; Vrijens, K.; Nawrot, T.; Van Nieuwenhuyse, A.; Van Loco, J.; Reyns, T. Simultaneous determination of parabens, bisphenols and alkylphenols in human placenta by ultra-high performance liquid chromatography-tandem mass spectrometry. $J$. Chromatogr. B 2019, 1121, 96-102. [CrossRef]

120. Valle-Sistac, J.; Molins-Delgado, D.; Díaz, M.; Ibáñez, L.; Barceló, D.; Díaz-Cruz, M.S. Determination of parabens and benzophenone-type UV filters in human placenta. First description of the existence of benzyl paraben and benzophenone-4. Environ. Int. 2016, 88, 243-249. [CrossRef]

121. Zhou, X.; Yang, Z.; Luo, Z.; Li, H.; Chen, G. Endocrine disrupting chemicals in wild freshwater fishes: Species, tissues, sizes and human health risks. Environ. Pollut. 2019, 244, 462-468. [CrossRef]

122. Liu, H.; Xu, Y.; Deng, X.; Gong, X.; Song, X.; Zhang, H.; Tian, X.; Zhang, X. Survey of bisphenol A contamination in Laizhou Bay. Prog. Fish. Sci. 2013, 34, 16-20.

123. Basheer, C.; Lee, H.K.; Tan, K.S. Endocrine disrupting alkylphenols and bisphenol-A in coastal waters and supermarket seafood from Singapore. Mar. Pollut. Bull. 2004, 48, 1161-1167. [CrossRef] [PubMed]

124. Peng, X.; Wang, Z.; Mai, B.; Chen, F.; Chen, S.; Tan, J.; Yu, Y.; Tang, C.; Li, K.; Zhang, G. Temporal trends of nonylphenol and bisphenol A contamination in the Pearl River Estuary and the adjacent South China Sea recorded by dated sedimentary cores. Sci. Total Environ. 2007, 384, 393-400. [CrossRef] [PubMed]

125. Ismail, N.A.H.; Wee, S.Y.; Kamarulzaman, N.H.; Aris, A.Z. Quantification of multi-classes of endocrine-disrupting compounds in estuarine water. Environ. Pollut. 2019, 249, 1019-1028. [CrossRef] [PubMed]

126. Yoon, Y.; Ryu, J.; Oh, J.; Choi, B.-G.; Snyder, S.A. Occurrence of endocrine disrupting compounds, pharmaceuticals, and personal care products in the Han River (Seoul, South Korea). Sci. Total Environ. 2010, 408, 636-643. [CrossRef]

127. Wee, S.Y.; Aris, A.Z.; Yusoff, F.M.; Praveena, S.M. Occurrence and risk assessment of multiclass endocrine disrupting compounds in an urban tropical river and a proposed risk management and monitoring framework. Sci. Total Environ. 2019, 671, 431-442. [CrossRef] [PubMed] 
128. Santhi, V.; Sakai, N.; Ahmad, E.; Mustafa, A. Occurrence of bisphenol A in surface water, drinking water and plasma from Malaysia with exposure assessment from consumption of drinking water. Sci. Total Environ. 2012, 427, 332-338. [CrossRef] [PubMed]

129. Ismail, N.A.H.; Wee, S.Y.; Aris, A.Z. Bisphenol A and alkylphenols concentrations in selected mariculture fish species from Pulau Kukup, Johor, Malaysia. Mar. Pollut. Bull. 2018, 127, 536-540. [CrossRef]

130. Pignotti, E.; Dinelli, E. Distribution and partition of endocrine disrupting compounds in water and sediment: Case study of the Romagna area (North Italy). J. Geochem. Explor. 2018, 195, 66-77. [CrossRef]

131. Ying, G.-G.; Kookana, R.S.; Kumar, A.; Mortimer, M. Occurrence and implications of estrogens and xenoestrogens in sewage effluents and receiving waters from South East Queensland. Sci. Total Environ. 2009, 407, 5147-5155. [CrossRef]

132. Wang, S.; Wu, W.; Liu, F.; Yin, S.; Bao, Z.; Liu, H. Spatial distribution and migration of nonylphenol in groundwater following long-term wastewater irrigation. J. Contam. Hydrol. 2015, 177, 85-92. [CrossRef] [PubMed]

133. Gong, J.; Ran, Y.; Chen, D.; Yang, Y.; Zeng, E.Y. Association of endocrine-disrupting chemicals with total organic carbon in riverine water and suspended particulate matter from the Pearl River, China. Environ. Toxicol. Chem. 2012, 31, 2456-2464. [CrossRef] [PubMed]

134. Carmona, E.; Andreu, V.; Picó, Y. Multi-residue determination of 47 organic compounds in water, soil, sediment and fish-Turia River as case study. J. Pharm. Biomed. Anal. 2017, 146, 117-125. [CrossRef] [PubMed]

135. Zhang, X.; Li, Q.; Li, G.; Wang, Z.; Yan, C. Levels of estrogenic compounds in Xiamen Bay sediment, China. Mar. Pollut. Bull. 2009, 58, 1210-1216. [CrossRef] [PubMed]

136. Klosterhaus, S.L.; Grace, R.; Hamilton, M.C.; Yee, D. Method validation and reconnaissance of pharmaceuticals, personal care products, and alkylphenols in surface waters, sediments, and mussels in an urban estuary. Environ. Int. 2013, 54, 92-99. [CrossRef]

137. Andreu, V.; Ferrer, E.; Rubio, J.L.; Font, G.; Picó, Y. Quantitative determination of octylphenol, nonylphenol, alkylphenol ethoxylates and alcohol ethoxylates by pressurized liquid extraction and liquid chromatography-mass spectrometry in soils treated with sewage sludges. Sci. Total Environ. 2007, 378, 124-129. [CrossRef]

138. Grześkowiak, T.; Czarczyńska-Goślińska, B.; Zgoła-Grześkowiak, A. Current approaches in sample preparation for trace analysis of selected endocrine-disrupting compounds: Focus on polychlorinated biphenyls, alkylphenols, and parabens. Trac Trends Anal. Chem. 2016, 75, 209-226. [CrossRef]

139. Oberdörster, E.; Cheek, A.O. Gender benders at the beach: Endocrine disruption in marine and estuarine organisms. Environ. Toxicol. Chem. Int. J. 2001, 20, 23-36. [CrossRef]

140. Errico, S.; Nicolucci, C.; Migliaccio, M.; Micale, V.; Mita, D.G.; Diano, N. Analysis and occurrence of some phenol endocrine disruptors in two marine sites of the northern coast of Sicily (Italy). Mar. Pollut. Bull. 2017, 120, 68-74. [CrossRef]

141. Ros, O.; Vallejo, A.; Olivares, M.; Etxebarria, N.; Prieto, A. Determination of endocrine disrupting compounds in fish liver, brain, and muscle using focused ultrasound solid-liquid extraction and dispersive solid phase extraction as clean-up strategy. Anal. Bioanal. Chem. 2016, 408, 5689-5700. [CrossRef]

142. Peng, X.; Zheng, K.; Liu, J.; Fan, Y.; Tang, C.; Xiong, S. Body size-dependent bioaccumulation, tissue distribution, and trophic and maternal transfer of phenolic endocrine-disrupting contaminants in a freshwater ecosystem. Environ. Toxicol. Chem. 2018, 37, 1811-1823. [CrossRef] [PubMed]

143. Lv, Y.-Z.; Yao, L.; Wang, L.; Liu, W.-R.; Zhao, J.-L.; He, L.-Y.; Ying, G.-G. Bioaccumulation, metabolism, and risk assessment of phenolic endocrine disrupting chemicals in specific tissues of wild fish. Chemosphere 2019, 226, 607-615. [CrossRef]

144. Wang, B.; Dong, F.; Chen, S.; Chen, M.; Bai, Y.; Tan, J.; Li, F.; Wang, Q. Phenolic endocrine disrupting chemicals in an urban receiving river (Panlong river) of Yunnan-Guizhou plateau: Occurrence, bioaccumulation and sources. Ecotoxicol. Environ. Saf. 2016, 128, 133-142. [CrossRef] [PubMed]

145. Salgueiro-González, N.; Turnes-Carou, I.; Viñas, L.; Besada, V.; Muniategui-Lorenzo, S.; López-Mahía, P.; Prada-Rodríguez, D. Occurrence of alkylphenols and bisphenol A in wild mussel samples from the Spanish Atlantic coast and Bay of Biscay. Mar. Pollut. Bull. 2016, 106, 360-365. [CrossRef] [PubMed]

146. López-Roldán, R.; de Alda, M.L.; Gros, M.; Petrovic, M.; Martín-Alonso, J.; Barceló, D. Advanced monitoring of pharmaceuticals and estrogens in the Llobregat River basin (Spain) by liquid chromatography-triple quadrupole-tandem mass spectrometry in combination with ultra performance liquid chromatography-time of flight-mass spectrometry. Chemosphere 2010, 80, 1337-1344. [CrossRef] [PubMed]

147. Brix, R.; Postigo, C.; González, S.; Villagrasa, M.; Navarro, A.; Kuster, M.; de Alda, M.J.L.; Barceló, D. Analysis and occurrence of alkylphenolic compounds and estrogens in a European river basin and an evaluation of their importance as priority pollutants. Anal. Bioanal. Chem. 2010, 396, 1301-1309. [CrossRef] [PubMed]

148. Pelayo, S.; López-Roldán, R.; González, S.; Casado, M.; Raldúa, D.; Cortina, J.L.; Piña, B. A zebrafish scale assay to monitor dioxin-like activity in surface water samples. Anal. Bioanal. Chem. 2011, 401, 1861. [CrossRef] [PubMed]

149. Zhang, Y.-Z.; Song, X.-F.; Kondoh, A.; Xia, J.; Tang, C.-Y. Behavior, mass inventories and modeling evaluation of xenobiotic endocrine-disrupting chemicals along an urban receiving wastewater river in Henan Province, China. Water Res. 2011, 45, 292-302. [CrossRef] [PubMed]

150. Wang, Q.; Wang, L.; Chen, X.; Rao, K.M.; Lu, S.Y.; Ma, S.T.; Jiang, P.; Zheng, D.; Xu, S.Q.; Zheng, H.Y. Increased urinary 8-hydroxy-2'-deoxyguanosine levels in workers exposed to di-(2-ethylhexyl) phthalate in a waste plastic recycling site in China. Environ. Sci. Pollut. Res. 2011, 18, 987-996. [CrossRef] [PubMed] 
151. Moreira, M.; Aquino, S.; Coutrim, M.; Silva, J.; Afonso, R. Determination of endocrine-disrupting compounds in waters from Rio das Velhas, Brazil, by liquid chromatography/high resolution mass spectrometry (ESI-LC-IT-TOF/MS). Environ. Technol. 2011, 32, 1409-1417. [CrossRef]

152. Lou, L.; Cheng, G.; Yang, Q.; Xu, X.; Hu, B.; Chen, Y. Development of a novel solid-phase extraction element for the detection of nonylphenol in the surface water of Hangzhou. J. Environ. Monit. 2012, 14, 517-523. [CrossRef]

153. Zhang, X.; Gao, Y.; Li, Q.; Li, G.; Guo, Q.; Yan, C. Estrogenic compounds and estrogenicity in surface water, sediments, and organisms from Yundang Lagoon in Xiamen, China. Arch. Environ. Contam. Toxicol. 2011, 61, 93-100. [CrossRef] [PubMed]

154. Esteban, S.; Moreno-Merino, L.; Matellanes, R.; Catalá, M.; Gorga, M.; Petrovic, M.; de Alda, M.L.; Barceló, D.; Silva, A.; Durán, J. Presence of endocrine disruptors in freshwater in the northern Antarctic Peninsula region. Environ. Res. 2016, 147, 179-192. [CrossRef]

155. Wang, L.; Ying, G.-G.; Chen, F.; Zhang, L.-J.; Zhao, J.-L.; Lai, H.-J.; Chen, Z.-F.; Tao, R. Monitoring of selected estrogenic compounds and estrogenic activity in surface water and sediment of the Yellow River in China using combined chemical and biological tools. Environ. Pollut. 2012, 165, 241-249. [CrossRef] [PubMed]

156. Luo, Z.; Tu, Y.; Li, H.; Qiu, B.; Liu, Y.; Yang, Z. Endocrine-disrupting compounds in the Xiangjiang River of China: Spatio-temporal distribution, source apportionment, and risk assessment. Ecotoxicol. Environ. Saf. 2019, 167, 476-484. [CrossRef] [PubMed]

157. Gong, J.; Xu, L.; Yang, Y.; Chen, D.-Y.; Ran, Y. Sequential ASE extraction of alkylphenols from sediments: Occurrence and environmental implications. J. Hazard. Mater. 2011, 192, 643-650. [CrossRef]

158. Montagner, C.C.; Jardim, W.F. Spatial and seasonal variations of pharmaceuticals and endocrine disruptors in the Atibaia River, São Paulo State (Brazil). J. Braz. Chem. Soc. 2011, 22, 1452-1462. [CrossRef]

159. Li, X.; Ying, G.-G.; Su, H.-C.; Yang, X.-B.; Wang, L. Simultaneous determination and assessment of 4-nonylphenol, bisphenol A and triclosan in tap water, bottled water and baby bottles. Environ. Int. 2010, 36, 557-562. [CrossRef]

160. Fan, J.-J.; Wang, S.; Tang, J.-P.; Zhao, J.-L.; Wang, L.; Wang, J.-X.; Liu, S.-L.; Li, F.; Long, S.-X.; Yang, Y. Bioaccumulation of endocrine disrupting compounds in fish with different feeding habits along the largest subtropical river, China. Environ. Pollut. 2019, 247, 999-1008. [CrossRef]

161. Ros, O.; Izaguirre, J.K.; Olivares, M.; Bizarro, C.; Ortiz-Zarragoitia, M.; Cajaraville, M.P.; Etxebarria, N.; Prieto, A.; Vallejo, A. Determination of endocrine disrupting compounds and their metabolites in fish bile. Sci. Total Environ. 2015, 536, 261-267. [CrossRef]

162. Chen, F.; Ying, G.-G.; Kong, L.-X.; Wang, L.; Zhao, J.-L.; Zhou, L.-J.; Zhang, L.-J. Distribution and accumulation of endocrinedisrupting chemicals and pharmaceuticals in wastewater irrigated soils in Hebei, China. Environ. Pollut. 2011, 159, 1490-1498. [CrossRef] [PubMed]

163. Diao, P.; Chen, Q.; Wang, R.; Sun, D.; Cai, Z.; Wu, H.; Duan, S. Phenolic endocrine-disrupting compounds in the Pearl River Estuary: Occurrence, bioaccumulation and risk assessment. Sci. Total Environ. 2017, 584, 1100-1107. [CrossRef] [PubMed]

164. Liu, D.; Wu, S.; Xu, H.; Zhang, Q.; Zhang, S.; Shi, L.; Yao, C.; Liu, Y.; Cheng, J. Distribution and bioaccumulation of endocrine disrupting chemicals in water, sediment and fishes in a shallow Chinese freshwater lake: Implications for ecological and human health risks. Ecotoxicol. Environ. Saf. 2017, 140, 222-229.

165. Yang, J.; Li, H.; Ran, Y.; Chan, K. Distribution and bioconcentration of endocrine disrupting chemicals in surface water and fish bile of the Pearl River Delta, South China. Chemosphere 2014, 107, 439-446. [CrossRef] [PubMed]

166. Miege, C.; Peretti, A.; Labadie, P.; Budzinski, H.; Le Bizec, B.; Vorkamp, K.; Tronczyński, J.; Persat, H.; Coquery, M.; Babut, M. Occurrence of priority and emerging organic compounds in fishes from the Rhone River (France). Anal. Bioanal. Chem. 2012, 404, 2721-2735. [CrossRef] [PubMed]

167. Mortazavi, S.; Bakhtiari, A.R.; Sari, A.E.; Bahramifar, N.; Rahbarizadeh, F. Occurrence of endocrine disruption chemicals (bisphenol a, 4-nonylphenol, and octylphenol) in muscle and liver of, Cyprinus carpino common, from Anzali Wetland, Iran. Bull. Environ. Contam. Toxicol. 2013, 90, 578-584. [CrossRef]

168. Liu, J.; Wang, R.; Huang, B.; Lin, C.; Wang, Y.; Pan, X. Distribution and bioaccumulation of steroidal and phenolic endocrine disrupting chemicals in wild fish species from Dianchi Lake, China. Environ. Pollut. 2011, 159, 2815-2822. [CrossRef] [PubMed]

169. Li, R.; Liang, J.; Gong, Z.; Zhang, N.; Duan, H. Occurrence, spatial distribution, historical trend and ecological risk of phthalate esters in the Jiulong River, Southeast China. Sci. Total Environ. 2017, 580, 388-397. [CrossRef]

170. Sun, J.; Huang, J.; Zhang, A.; Liu, W.; Cheng, W. Occurrence of phthalate esters in sediments in Qiantang River, China and inference with urbanization and river flow regime. J. Hazard. Mater. 2013, 248, 142-149. [CrossRef]

171. Gao, X.; Li, J.; Wang, X.; Zhou, J.; Fan, B.; Li, W.; Liu, Z. Exposure and ecological risk of phthalate esters in the Taihu Lake basin, China. Ecotoxicol. Environ. Saf. 2019, 171, 564-570. [CrossRef]

172. Zhang, W.; Han, Y.; Lu, L.; Zhao, T. An analysis of water environmental pollution in the Taige Canal watershed. China Rural Water Hydropower 2012, 9, 47-50.

173. He, W.; Qin, N.; Kong, X.; Liu, W.; He, Q.; Ouyang, H.; Yang, C.; Jiang, Y.; Wang, Q.; Yang, B. Spatio-temporal distributions and the ecological and health risks of phthalate esters (PAEs) in the surface water of a large, shallow Chinese lake. Sci. Total Environ. 2013, 461, 672-680. [CrossRef] [PubMed]

174. Wang, H.; Wang, C.; Wu, W.; Mo, Z.; Wang, Z. Persistent organic pollutants in water and surface sediments of Taihu Lake, China and risk assessment. Chemosphere 2003, 50, 557-562. [CrossRef] 
175. Jiang, J.; Mu, D.; Ding, M.; Zhang, S.; Zhang, H.; Hu, J. Simultaneous determination of primary and secondary phthalate monoesters in the Taihu Lake: Exploration of sources. Chemosphere 2018, 202, 17-24. [CrossRef] [PubMed]

176. Ji, M.; Li, S.; Zhang, J.; Di, H.; Li, F.; Feng, T. The human health assessment to phthalate acid esters (PAEs) and potential probability prediction by chromophoric dissolved organic matter EEM-FRI fluorescence in Erlong Lake. Int. J. Environ. Res. Public Health 2018, 15, 1109. [CrossRef] [PubMed]

177. Cho, E.; Khim, J.; Chung, S.; Seo, D.; Son, Y. Occurrence of micropollutants in four major rivers in Korea. Sci. Total Environ. 2014, 491, 138-147. [CrossRef] [PubMed]

178. Zheng, X.; Zhang, B.-T.; Teng, Y. Distribution of phthalate acid esters in lakes of Beijing and its relationship with anthropogenic activities. Sci. Total Environ. 2014, 476, 107-113. [CrossRef]

179. He, Y.; Wang, Q.; He, W.; Xu, F. The occurrence, composition and partitioning of phthalate esters (PAEs) in the water-suspended particulate matter (SPM) system of Lake Chaohu, China. Sci. Total Environ. 2019, 661, 285-293. [CrossRef]

180. Bianucci, L.; Balaguru, K.; Smith, R.W.; Leung, L.R.; Moriarty, J.M. Contribution of hurricane-induced sediment resuspension to coastal oxygen dynamics. Sci. Rep. 2018, 8, 15740. [CrossRef]

181. Tran, B.C.; Teil, M.-J.; Blanchard, M.; Alliot, F.; Chevreuil, M. Fate of phthalates and BPA in agricultural and non-agricultural soils of the Paris area (France). Environ. Sci. Pollut. Res. 2015, 22, 11118-11126. [CrossRef]

182. Škrbić, B.D.; Ji, Y.; Đurišić-Mladenović, N.; Zhao, J. Occurence of the phthalate esters in soil and street dust samples from the Novi Sad city area, Serbia, and the influence on the children's and adults' exposure. J. Hazard. Mater. 2016, 312, 272-279. [CrossRef]

183. Guo, D.; Wu, Y. Determination of phthalic acid esters of soil in south of Xinjiang cotton fields. Arid Environ. Monit. 2011, 25, 76-79.

184. Wu, W.; Hu, J.; Wang, J.; Chen, X.; Yao, N.; Tao, J.; Zhou, Y.-K. Analysis of phthalate esters in soils near an electronics manufacturing facility and from a non-industrialized area by gas purge microsyringe extraction and gas chromatography. Sci. Total Environ. 2015, 508, 445-451. [CrossRef]

185. Lü, H.; Mo, C.-H.; Zhao, H.-M.; Xiang, L.; Katsoyiannis, A.; Li, Y.-W.; Cai, Q.-Y.; Wong, M.-H. Soil contamination and sources of phthalates and its health risk in China: A review. Environ. Res. 2018, 164, 417-429. [CrossRef]

186. Zhang, H.; Sun, G.; Sun, L.; Zhou, Z.; Zhang, S.; Sui, H. Preliminary study on phthalic acid esters pollution of typical plastic mulched crops soils. Env. Monit China 2013, 29, 60-63.

187. Niu, L.; Xu, Y.; Xu, C.; Yun, L.; Liu, W. Status of phthalate esters contamination in agricultural soils across China and associated health risks. Environ. Pollut. 2014, 195, 16-23. [CrossRef] [PubMed]

188. Xia, X.; Yang, L.; Bu, Q.; Liu, R. Levels, distribution, and health risk of phthalate esters in urban soils of Beijing, China. J. Environ. Qual. 2011, 40, 1643-1651. [CrossRef] [PubMed]

189. Adeniyi, A.A.; Okedeyi, O.O.; Yusuf, K.A. Flame ionization gas chromatographic determination of phthalate esters in water, surface sediments and fish species in the Ogun river catchments, Ketu, Lagos, Nigeria. Environ. Monit. Assess. 2011, 172, 561-569. [CrossRef]

190. Huang, P.-C.; Tien, C.-J.; Sun, Y.-M.; Hsieh, C.-Y.; Lee, C.-C. Occurrence of phthalates in sediment and biota: Relationship to aquatic factors and the biota-sediment accumulation factor. Chemosphere 2008, 73, 539-544. [CrossRef]

191. Gao, D.; Li, Z.; Wen, Z.; Ren, N. Occurrence and fate of phthalate esters in full-scale domestic wastewater treatment plants and their impact on receiving waters along the Songhua River in China. Chemosphere 2014, 95, 24-32. [CrossRef]

192. Paluselli, A.; Aminot, Y.; Galgani, F.; Net, S.; Sempere, R. Occurrence of phthalate acid esters (PAEs) in the northwestern Mediterranean Sea and the Rhone River. Prog. Oceanogr. 2018, 163, 221-231. [CrossRef]

193. Mousa, A.; Basheer, C.; Al-Arfaj, A.R. Application of electro-enhanced solid-phase microextraction for determination of phthalate esters and bisphenol A in blood and seawater samples. Talanta 2013, 115, 308-313. [CrossRef]

194. Liu, H.; Cui, K.; Zeng, F.; Chen, L.; Cheng, Y.; Li, H.; Li, S.; Zhou, X.; Zhu, F.; Ouyang, G. Occurrence and distribution of phthalate esters in riverine sediments from the Pearl River Delta region, South China. Mar. Pollut. Bull. 2014, 83, 358-365. [CrossRef] [PubMed]

195. Srivastava, A.; Sharma, V.P.; Tripathi, R.; Kumar, R.; Patel, D.K.; Mathur, P.K. Occurrence of phthalic acid esters in Gomti River Sediment, India. Environ. Monit. Assess. 2010, 169, 397-406. [CrossRef]

196. Tavares, R.S.; Martins, F.C.; Oliveira, P.J.; Ramalho-Santos, J.; Peixoto, F.P. Parabens in male infertility-Is there a mitochondrial connection? Reprod. Toxicol. 2009, 27, 1-7. [CrossRef] [PubMed]

197. Ishiwatari, S.; Suzuki, T.; Hitomi, T.; Yoshino, T.; Matsukuma, S.; Tsuji, T. Effects of methyl paraben on skin keratinocytes. J. Appl. Toxicol. Int. J. 2007, 27, 1-9. [CrossRef] [PubMed]

198. Janjua, N.R.; Mortensen, G.K.; Andersson, A.-M.; Kongshoj, B.; Skakkebaek, N.E.; Wulf, H.C. Systemic uptake of diethyl phthalate, dibutyl phthalate, and butyl paraben following whole-body topical application and reproductive and thyroid hormone levels in humans. Environ. Sci. Technol. 2007, 41, 5564-5570. [CrossRef]

199. Meeker, J.D.; Yang, T.; Ye, X.; Calafat, A.M.; Hauser, R. Urinary concentrations of parabens and serum hormone levels, semen quality parameters, and sperm DNA damage. Environ. Health Perspect. 2011, 119, 252-257. [CrossRef] [PubMed]

200. Koeppe, E.S.; Ferguson, K.K.; Colacino, J.A.; Meeker, J.D. Relationship between urinary triclosan and paraben concentrations and serum thyroid measures in NHANES 2007-2008. Sci. Total Environ. 2013, 445, 299-305. [CrossRef] [PubMed]

201. Ye, X.; Tao, L.J.; Needham, L.L.; Calafat, A.M. Automated on-line column-switching HPLC-MS/MS method for measuring environmental phenols and parabens in serum. Talanta 2008, 76, 865-871. [CrossRef] 
202. Jiménez-Díaz, I.; Vela-Soria, F.; Zafra-Gómez, A.; Navalón, A.; Ballesteros, O.; Navea, N.; Fernández, M.; Olea, N.; Vílchez, J. A new liquid chromatography-tandem mass spectrometry method for determination of parabens in human placental tissue samples. Talanta 2011, 84, 702-709. [CrossRef] [PubMed]

203. Alonso, M.B.; Feo, M.L.; Corcellas, C.; Gago-Ferrero, P.; Bertozzi, C.P.; Marigo, J.; Flach, L.; Meirelles, A.C.O.; Carvalho, V.L.; Azevedo, A.F. Toxic heritage: Maternal transfer of pyrethroid insecticides and sunscreen agents in dolphins from Brazil. Environ. Pollut. 2015, 207, 391-402. [CrossRef]

204. Vela-Soria, F.; Ballesteros, O.; Camino-Sánchez, F.; Zafra-Gómez, A.; Ballesteros, L.; Navalón, A. Matrix solid phase dispersion for the extraction of selected endocrine disrupting chemicals from human placental tissue prior to UHPLC-MS/MS analysis. Microchem. J. 2015, 118, 32-39. [CrossRef]

205. Vela-Soria, F.; Jiménez-Díaz, I.; Rodríguez-Gómez, R.; Zafra-Gómez, A.; Ballesteros, O.; Fernández, M.; Olea, N.; Navalón, A. A multiclass method for endocrine disrupting chemical residue analysis in human placental tissue samples by UHPLC-MS/MS. Anal. Methods 2011, 3, 2073-2081. [CrossRef]

206. Vela-Soria, F.; Jiménez-Díaz, I.; Rodríguez-Gómez, R.; Zafra-Gómez, A.; Ballesteros, O.; Navalón, A.; Vílchez, J.; Fernández, M.; Olea, N. Determination of benzophenones in human placental tissue samples by liquid chromatography-tandem mass spectrometry. Talanta 2011, 85, 1848-1855. [CrossRef]

207. Dewalque, L.; Pirard, C.; Charlier, C. Measurement of urinary biomarkers of parabens, benzophenone-3, and phthalates in a Belgian population. Biomed Res. Int. 2014, 2014, 649314. [CrossRef]

208. UNION, P. Regulation (EC) No 1223/2009 of the european parliament and of the council. Off. J. Eur. Union L 2009, $342,59$.

209. Hu, P.; Chen, X.; Whitener, R.J.; Boder, E.T.; Jones, J.O.; Porollo, A.; Chen, J.; Zhao, L. Effects of parabens on adipocyte differentiation. Toxicol. Sci. 2013, 131, 56-70. [CrossRef] [PubMed]

210. Hu, Y.; Zhang, Z.; Sun, L.; Zhu, D.; Liu, Q.; Jiao, J.; Li, J.; Qi, M. The estrogenic effects of benzylparaben at low doses based on uterotrophic assay in immature SD rats. Food Chem. Toxicol. 2013, 53, 69-74. [CrossRef] [PubMed]

211. Freire, C.; Molina-Molina, J.-M.; Iribarne-Durán, L.M.; Jiménez-Díaz, I.; Vela-Soria, F.; Mustieles, V.; Arrebola, J.P.; Fernández, M.F.; Artacho-Cordón, F.; Olea, N. Concentrations of bisphenol A and parabens in socks for infants and young children in Spain and their hormone-like activities. Environ. Int. 2019, 127, 592-600. [CrossRef] [PubMed]

212. Zhang, T.; Sun, H.; Qin, X.; Wu, Q.; Zhang, Y.; Ma, J.; Kannan, K. Benzophenone-type UV filters in urine and blood from children, adults, and pregnant women in China: Partitioning between blood and urine as well as maternal and fetal cord blood. Sci. Total Environ. 2013, 461, 49-55. [CrossRef] [PubMed]

213. Lee, Y.J.; Ryu, H.-Y.; Kim, H.-K.; Min, C.S.; Lee, J.H.; Kim, E.; Nam, B.H.; Park, J.H.; Jung, J.Y.; Jang, D.D. Maternal and fetal exposure to bisphenol A in Korea. Reprod. Toxicol. 2008, 25, 413-419. [CrossRef] [PubMed]

214. Pinney, S.E.; Mesaros, C.A.; Snyder, N.W.; Busch, C.M.; Xiao, R.; Aijaz, S.; Ijaz, N.; Blair, I.A.; Manson, J.M. Second trimester amniotic fluid bisphenol A concentration is associated with decreased birth weight in term infants. Reprod. Toxicol. 2017, 67, 1-9. [CrossRef] [PubMed]

215. Kabir, E.R.; Rahman, M.S.; Rahman, I. A review on endocrine disruptors and their possible impacts on human health. Environ. Toxicol. Pharmacol. 2015, 40, 241-258. [CrossRef] [PubMed]

216. Vandenberg, L.N.; Colborn, T.; Hayes, T.B.; Heindel, J.J.; Jacobs, D.R., Jr.; Lee, D.-H.; Shioda, T.; Soto, A.M.; vom Saal, F.S.; Welshons, W.V. Hormones and endocrine-disrupting chemicals: Low-dose effects and nonmonotonic dose responses. Endocr. Rev. 2012, 33, 378-455. [CrossRef]

217. Mallozzi, M.; Bordi, G.; Garo, C.; Caserta, D. The effect of maternal exposure to endocrine disrupting chemicals on fetal and neonatal development: A review on the major concerns. Birth Defects Res. Part C Embryo Today Rev. 2016, 108, 224-242. [CrossRef]

218. Fisher, M.; MacPherson, S.; Braun, J.M.; Hauser, R.; Walker, M.; Feeley, M.; Mallick, R.; Bérubé, R.; Arbuckle, T.E. Paraben concentrations in maternal urine and breast milk and its association with personal care product use. Environ. Sci. Technol. 2017, 51, 4009-4017. [CrossRef]

219. Fotouhi, M.; Seidi, S.; Shanehsaz, M.; Naseri, M.T. Magnetically assisted matrix solid phase dispersion for extraction of parabens from breast milks. J. Chromatogr. A 2017, 1504, 17-26. [CrossRef]

220. Rodríguez-Gómez, R.; Zafra-Gómez, A.; Camino-Sánchez, F.; Ballesteros, O.; Navalón, A. Gas chromatography and ultra high performance liquid chromatography tandem mass spectrometry methods for the determination of selected endocrine disrupting chemicals in human breast milk after stir-bar sorptive extraction. J. Chromatogr. A 2014, 1349, 69-79. [CrossRef]

221. Ye, X.; Bishop, A.M.; Needham, L.L.; Calafat, A.M. Automated on-line column-switching HPLC-MS/MS method with peak focusing for measuring parabens, triclosan, and other environmental phenols in human milk. Anal. Chim. Acta 2008, 622, 150-156. [CrossRef]

222. Lee, J.; Choi, K.; Park, J.; Moon, H.-B.; Choi, G.; Lee, J.J.; Suh, E.; Kim, H.-J.; Eun, S.-H.; Kim, G.-H. Bisphenol A distribution in serum, urine, placenta, breast milk, and umbilical cord serum in a birth panel of mother-neonate pairs. Sci. Total Environ. 2018, 626, 1494-1501. [CrossRef] [PubMed]

223. Sakhi, A.K.; Sabaredzovic, A.; Papadopoulou, E.; Cequier, E.; Thomsen, C. Levels, variability and determinants of environmental phenols in pairs of Norwegian mothers and children. Environ. Int. 2018, 114, 242-251. [CrossRef] [PubMed]

224. Kolatorova, L.; Vitku, J.; Hampl, R.; Adamcova, K.; Skodova, T.; Simkova, M.; Parizek, A.; Starka, L.; Duskova, M. Exposure to bisphenols and parabens during pregnancy and relations to steroid changes. Environ. Res. 2018, 163, 115-122. [CrossRef] [PubMed] 
225. Balakrishnan, B.; Henare, K.; Thorstensen, E.B.; Ponnampalam, A.P.; Mitchell, M.D. Transfer of bisphenol A across the human placenta. Am. J. Obstet. Gynecol. 2010, 202, 393.e1-393.e7. [CrossRef]

226. Takahashi, O.; Oishi, S. Disposition of orally administered 2, 2-Bis (4-hydroxyphenyl) propane (Bisphenol A) in pregnant rats and the placental transfer to fetuses. Environ. Health Perspect. 2000, 108, 931-935. [CrossRef]

227. Wan, Y.; Choi, K.; Kim, S.; Ji, K.; Chang, H.; Wiseman, S.; Jones, P.D.; Khim, J.S.; Park, S.; Park, J. Hydroxylated polybrominated diphenyl ethers and bisphenol A in pregnant women and their matching fetuses: Placental transfer and potential risks. Environ. Sci. Technol. 2010, 44, 5233-5239. [CrossRef]

228. Kosarac, I.; Kubwabo, C.; Lalonde, K.; Foster, W. A novel method for the quantitative determination of free and conjugated bisphenol A in human maternal and umbilical cord blood serum using a two-step solid phase extraction and gas chromatography/tandem mass spectrometry. J. Chromatogr. B 2012, 898, 90-94. [CrossRef]

229. Minatoya, M.; Araki, A.; Nakajima, S.; Sasaki, S.; Miyashita, C.; Yamazaki, K.; Yamamoto, J.; Matumura, T.; Kishi, R. Cord blood BPA level and child neurodevelopment and behavioral problems: The Hokkaido Study on Environment and Children's Health. Sci. Total Environ. 2017, 607, 351-356. [CrossRef]

230. Teeguarden, J.G.; Twaddle, N.C.; Churchwell, M.I.; Doerge, D.R. Urine and serum biomonitoring of exposure to environmental estrogens I: Bisphenol A in pregnant women. Food Chem. Toxicol. 2016, 92, 129-142. [CrossRef]

231. Kuruto-Niwa, R.; Tateoka, Y.; Usuki, Y.; Nozawa, R. Measurement of bisphenol A concentrations in human colostrum. Chemosphere 2007, 66, 1160-1164. [CrossRef]

232. Braun, J.M.; Yolton, K.; Stacy, S.L.; Erar, B.; Papandonatos, G.D.; Bellinger, D.C.; Lanphear, B.P.; Chen, A. Prenatal environmental chemical exposures and longitudinal patterns of child neurobehavior. Neurotoxicology 2017, 62, 192-199. [CrossRef] [PubMed]

233. Nadal, A.; Quesada, I.; Tudurí, E.; Nogueiras, R.; Alonso-Magdalena, P. Endocrine-disrupting chemicals and the regulation of energy balance. Nat. Rev. Endocrinol. 2017, 13, 536. [CrossRef] [PubMed]

234. Fernández, M.; Bourguignon, N.; Lux-Lantos, V.; Libertun, C. Neonatal exposure to bisphenol a and reproductive and endocrine alterations resembling the polycystic ovarian syndrome in adult rats. Environ. Health Perspect. 2010, 118, 1217-1222. [CrossRef] [PubMed]

235. Cantonwine, D.E.; Ferguson, K.K.; Mukherjee, B.; McElrath, T.F.; Meeker, J.D. Urinary bisphenol A levels during pregnancy and risk of preterm birth. Environ. Health Perspect. 2015, 123, 895-901. [CrossRef]

236. Li, A.J.; Kannan, K. Elevated concentrations of bisphenols, benzophenones, and antimicrobials in pantyhose collected from six countries. Environ. Sci. Technol. 2018, 52, 10812-10819. [CrossRef]

237. Molina-Molina, J.-M.; Amaya, E.; Grimaldi, M.; Sáenz, J.-M.; Real, M.; Fernandez, M.F.; Balaguer, P.; Olea, N. In vitro study on the agonistic and antagonistic activities of bisphenol-S and other bisphenol-A congeners and derivatives via nuclear receptors. Toxicol. Appl. Pharmacol. 2013, 272, 127-136. [CrossRef]

238. DeMatteo, R.; Keith, M.M.; Brophy, J.T.; Wordsworth, A.; Watterson, A.E.; Beck, M.; Rochon, A.; Michael, F.; Jyoti, G.; Magali, P. Chemical exposures of women workers in the plastics industry with particular reference to breast cancer and reproductive hazards. New Solut. J. Environ. Occup. Health Policy 2013, 22, 427-448. [CrossRef]

239. Le Magueresse-Battistoni, B.; Multigner, L.; Beausoleil, C.; Rousselle, C. Effects of bisphenol A on metabolism and evidences of a mode of action mediated through endocrine disruption. Mol. Cell. Endocrinol. 2018, 475, 74-91. [CrossRef]

240. Kay, V.R.; Chambers, C.; Foster, W.G. Reproductive and developmental effects of phthalate diesters in females. Crit. Rev. Toxicol. 2013, 43, 200-219. [CrossRef] [PubMed]

241. Radke, E.G.; Braun, J.M.; Meeker, J.D.; Cooper, G.S. Phthalate exposure and male reproductive outcomes: A systematic review of the human epidemiological evidence. Environ. Int. 2018, 121, 764-793. [CrossRef]

242. Bamai, Y.A.; Araki, A.; Nomura, T.; Kawai, T.; Tsuboi, T.; Kobayashi, S.; Miyashita, C.; Takeda, M.; Shimizu, H.; Kishi, R. Association of filaggrin gene mutations and childhood eczema and wheeze with phthalates and phosphorus flame retardants in house dust: The Hokkaido study on Environment and Children's Health. Environ. Int. 2018, 121, 102-110. [CrossRef] [PubMed]

243. Shi, W.; Lin, Z.; Liao, C.; Zhang, J.; Liu, W.; Wang, X.; Cai, J.; Zou, Z.; Wang, H.; Norback, D. Urinary phthalate metabolites in relation to childhood asthmatic and allergic symptoms in Shanghai. Environ. Int. 2018, 121, 276-286. [CrossRef] [PubMed]

244. Amin, M.M.; Ebrahimpour, K.; Parastar, S.; Shoshtari-Yeganeh, B.; Hashemi, M.; Mansourian, M.; Poursafa, P.; Fallah, Z.; Rafiei, N.; Kelishadi, R. Association of urinary concentrations of phthalate metabolites with cardiometabolic risk factors and obesity in children and adolescents. Chemosphere 2018, 211, 547-556. [CrossRef] [PubMed]

245. Tan, S.; Wang, D.; Chi, Z.; Li, W.; Shan, Y. Study on the interaction between typical phthalic acid esters (PAEs) and human haemoglobin $(\mathrm{hHb})$ by molecular docking. Environ. Toxicol. Pharmacol. 2017, 53, 206-211. [CrossRef] [PubMed]

246. Trasande, L.; Spanier, A.J.; Sathyanarayana, S.; Attina, T.M.; Blustein, J. Urinary phthalates and increased insulin resistance in adolescents. Pediatrics 2013, 132, e646-e655. [CrossRef] [PubMed]

247. Zhai, W.; Huang, Z.; Chen, L.; Feng, C.; Li, B.; Li, T. Thyroid endocrine disruption in zebrafish larvae after exposure to mono-(2-ethylhexyl) phthalate (MEHP). PLoS ONE 2014, 9, e92465. [CrossRef]

248. Martinez-Arguelles, D.B.; Papadopoulos, V. Prenatal phthalate exposure: Epigenetic changes leading to lifelong impact on steroid formation. Andrology 2016, 4, 573-584. [CrossRef]

249. Hannon, P.R.; Flaws, J.A. The effects of phthalates on the ovary. Front. Endocrinol. 2015, 6, 8. [CrossRef] 
250. Dodge, L.; Williams, P.; Williams, M.; Missmer, S.; Souter, I.; Calafat, A.; Hauser, R.; Team, E.S. Associations between paternal urinary phthalate metabolite concentrations and reproductive outcomes among couples seeking fertility treatment. Reprod. Toxicol. 2015, 58, 184-193. [CrossRef]

251. Hauser, R.; Gaskins, A.J.; Souter, I.; Smith, K.W.; Dodge, L.E.; Ehrlich, S.; Meeker, J.D.; Calafat, A.M.; Williams, P.L.; Team, E.S. Urinary phthalate metabolite concentrations and reproductive outcomes among women undergoing in vitro fertilization: Results from the EARTH study. Environ. Health Perspect. 2016, 124, 831-839. [CrossRef]

252. Al-Saleh, I.; Coskun, S.; Al-Doush, I.; Abduljabbar, M.; Al-Rouqi, R.; Al-Rajudi, T.; Al-Hassan, S. Couples exposure to phthalates and its influence on in vitro fertilization outcomes. Chemosphere 2019, 226, 597-606. [CrossRef] [PubMed]

253. Choi, W.; Kim, S.; Baek, Y.-W.; Choi, K.; Lee, K.; Kim, S.; Do Yu, S.; Choi, K. Exposure to environmental chemicals among Korean adults-updates from the second Korean National Environmental Health Survey (2012-2014). Int. J. Hyg. Environ. Health 2017, 220, 29-35. [CrossRef] [PubMed]

254. Haines, D.A.; Saravanabhavan, G.; Werry, K.; Khoury, C. An overview of human biomonitoring of environmental chemicals in the Canadian Health Measures Survey: 2007-2019. Int. J. Hyg. Environ. Health 2017, 220, 13-28. [CrossRef]

255. Machtinger, R.; Gaskins, A.J.; Racowsky, C.; Mansur, A.; Adir, M.; Baccarelli, A.A.; Calafat, A.M.; Hauser, R. Urinary concentrations of biomarkers of phthalates and phthalate alternatives and IVF outcomes. Environ. Int. 2018, 111, 23-31. [CrossRef] [PubMed]

256. Bu, Z.; Mmereki, D.; Wang, J.; Dong, C. Exposure to commonly-used phthalates and the associated health risks in indoor environment of urban China. Sci. Total Environ. 2019, 658, 843-853. [CrossRef] [PubMed]

257. Fromme, H.; Gruber, L.; Seckin, E.; Raab, U.; Zimmermann, S.; Kiranoglu, M.; Schlummer, M.; Schwegler, U.; Smolic, S.; Völkel, W. Phthalates and their metabolites in breast milk—results from the Bavarian Monitoring of Breast Milk (BAMBI). Environ. Int. 2011, 37, 715-722. [CrossRef] [PubMed]

258. Correia-Sá, L.; Kasper-Sonnenberg, M.; Pälmke, C.; Schütze, A.; Norberto, S.; Calhau, C.; Domingues, V.F.; Koch, H.M. Obesity or diet? Levels and determinants of phthalate body burden-A case study on Portuguese children. Int. J. Hyg. Environ. Health 2018, 221, 519-530. [CrossRef]

259. Garí, M.; Koch, H.M.; Pälmke, C.; Jankowska, A.; Wesołowska, E.; Hanke, W.; Nowak, D.; Bose-O’Reilly, S.; Polańska, K. Determinants of phthalate exposure and risk assessment in children from Poland. Environ. Int. 2019, 127, 742-753. [CrossRef] [PubMed]

260. Darbre, P.D. Endocrine disruptors and obesity. Curr. Obes. Rep. 2017, 6, 18-27. [CrossRef] [PubMed]

261. Attina, T.M.; Hauser, R.; Sathyanarayana, S.; Hunt, P.A.; Bourguignon, J.-P.; Myers, J.P.; DiGangi, J.; Zoeller, R.T.; Trasande, L. Exposure to endocrine-disrupting chemicals in the USA: A population-based disease burden and cost analysis. Lancet Diabetes Endocrinol. 2016, 4, 996-1003. [CrossRef] 